Florida International University FIU Digital Commons

$11-10-2010$

\title{
A multi-scale and multi-approach investigation of sediment yield and runoff flux in the Mara River basin, Kenya
}

Mengistu Balew Defersha

Florida International University

DOI: $10.25148 /$ etd.FI14062232

Follow this and additional works at: https://digitalcommons.fiu.edu/etd

Part of the Environmental Studies Commons

\section{Recommended Citation}

Defersha, Mengistu Balew, "A multi-scale and multi-approach investigation of sediment yield and runoff flux in the Mara River basin, Kenya" (2010). FIU Electronic Theses and Dissertations. 2762.

https://digitalcommons.fiu.edu/etd/2762 
FLORIDA INTERNATIONAL UNIVERSITY

Miami, Florida

\section{A MULTI-SCALE AND MULTI-APPROACH INVESTIGATION OF SEDIMENT YIELD AND RUNOFF FLUX IN THE MARA RIVER BASIN, KENYA}

A thesis submitted in partial fulfillment of the

requirements for the degree of

MASTER OF SCIENCE

in

ENVIRONMENTAL STUDIES

by

Mengistu Balew Defersha 
To: Dean Kenneth Furton

College of Arts and Sciences

This thesis, written by Mengistu Balew Defersha, and entitled A Multi-scale and Multiapproach Investigation of Sediment Yield and Runoff Flux in the Mara River Basin, Kenya, having been approved in respect to style and intellectual content, is referred to you for judgment.

We have read this thesis and recommend that it be approved.

MithaeLE. McClain

Leonard J. Scinto

Fernando R. Miralles-Wilhelm

Assefa M. Melesse, Major Professor

Date of Defense: November 10, 2010

The thesis of Mengistu Balew Defersha is approved.

Dean Kenneth Furton College of Arts and Sciences

Interim Dean Kevin O'Shea University Graduate School

Florida International University, 2010 


\section{ACKNOWLEDGMENTS}

I wish to acknowledge members of my committee for their guidance and support. With the deep sense of veneration and obligation from the core of my heart, I take this opportunity to express my special gratitude to my major Advisor Dr. Assefa Melesse and committee member Dr. Michael McClain for their inspiration and professional assistance, continuous patience, concrete suggestions, encouragement, and valuable criticism all the way from the outset to the completion of this study.

Dr. Assefa Melesse has provided physical and moral support throughout this study. Without his support, the study could not have been completed. I would like to thank Dr. Fernando Miralles, and Dr. Leonard Scinto for their feedback, direction, and assistance when I needed it.

A special word of gratitude is to Amanda Subalusky, Shimelis Dessu, and Christopher for their generous support and technical assistance during site selection and construction of the field plots as well as data collection during the entire study period. My sincere thanks also go to my colleagues: Fukhrudin Khalif, Yirgalem Chebud, Liya Mango, and Dr. Shimelis Setegn who directly or indirectly contributed for the success of my thesis work. Fukhrudin Khalif and Yirgalem Chebud deserve special thanks for the discussion we had made and for the valuable ideas they provided me during the conception period of the research and for their unending benevolent during my course and thesis work. I extend my earnest feeling to acknowledge all the staff members and students of Florida International University, Department of Earth and Environment who directly or indirectly lent their cooperation during the study period. 
I thank the Nairobi and Narok WWF staff members for providing valuable data resources and support throughout the study period in Kenya. I am especially thankful to the residents of the Mara basin especially, the farmers in Amala and Nyangores watersheds. I would like to acknowledge Global Water for Sustainability (GLOWS) Program for funding the research via the United States Agency for International Development (USAID).

Finally, special recognition goes out to my family, for their support, encouragement and patience during my study. To my lovely wife Firehiwot Tamene, who inspired me and provided constant encouragement during the entire process. To my little daughter, Rehaniya Mengistu, who missed out on a lot of Daddy time while I sought intellectual enlightenment. I thank you for your patience and love you more than you will ever know. Above all loving kindness and faithfulness of the Almighty God in supplying health, endurance, and protection throughout the study is gratefully appreciated 
ABSTRACT OF THE THESIS

\section{A MULTI-SCALE AND MULTI-APPROACH INVESTIGATION OF SEDIMENT \\ YIELD AND RUNOFF FLUX IN THE MARA RIVER BASIN, KENYA}

by

Mengistu Balew Defersha

Florida International University, 2010

Miami, Florida

Professor Assefa M. Melesse, Major Professor

The purposes of this study were to identify the current potential sediment source areas and quantify rate of erosion and runoff. Runoff plots were established at three sites and the Water Erosion Prediction Project (WEPP) and Erosion 3D models were applied at watershed scale. The highest total sediment yield was observed on cultivated land $\left(162.38 \mathrm{~g} / \mathrm{m}^{2}\right)$ in the Nyangores sub-watershed and the lowest sediment yield $(29.95$ $\mathrm{g} / \mathrm{m}^{2}$ ) was observed on grassland, in Amala downstream. The model evaluation indicated that both of the models perform well in estimation of runoff, however, the WEPP model performs better than Erosion 3D in estimation of erosion. At watershed scale, the simulation result indicated that average erosion in cultivated land was about 120 tons/ha/year and the lowest erosion rate was estimated on bush lands and grass lands, which may indicate change in land use has significant impact on soil erosion in the Mara River basin 
Chapter 1

1.0 Introduction

1.1 Background

1.2 Statement of the problem

1.3 Justification of the Study

1.4 Research questions

1.5 Objectives

Chapter 2

2.0 Literature Review

2.1 Soil erosion and land degradation $\quad 7$

$\begin{array}{ll}\text { 2.1.1 Land degradation } & 7\end{array}$

2.1.2 Factors influencing soil erosion $\quad 8$

$\begin{array}{lr}2.1 .3 \text { Soil erosion processes } & 10\end{array}$

2.2 Soil erosion Experiment 11

2.3 Runoff plots in soil erosion experiment 11

2.4 Modeling Soil Erosion $\quad 12$

2.4.1 Background of Erosion 3D and Erosion 2D 13

$\begin{array}{ll}\text { 2.4.1.1 Overview } & 13\end{array}$

2.4.1.2 Physical modeling algorithms (Slope and surface flow model) 14

2.4.1.3 Erosion and deposition model (Erosion 3D) 17

2.4.2 Water Erosion Prediction Project (WEPP) model 22

$\begin{array}{ll}\text { 2.4.2.2 Erosion and deposition } & 26\end{array}$

$\begin{array}{ll}\text { Chapter } 3 & 29\end{array}$

3.0 Material and Methods $\quad 29$

$\begin{array}{ll}3.1 \text { Description of the study area } & 29\end{array}$

$\begin{array}{ll}3.1 .1 \text { Location } & 29\end{array}$

3.1.2 Land use/Land covers $\quad 30$

3.1.3. Soil types in the Mara River basin 31

3.1.4 Rainfall distribution in the Mara River basin 33

$\begin{array}{ll}3.2 \text { Experimental Procedures } & 34\end{array}$

3.2.1 Procedures at field plot scale 34

3.2.2 Model Performance Evaluation 38

3.2.3 Application of Erosion 3D model at watershed level 41

$\begin{array}{ll}\text { Chapter } 4 & 44\end{array}$

4.0 Results and Discussions $\quad 44$

4.1 Land cover change, runoff rate and sediment yield 44

4.1.1 Sediment variation in the Amala upstream 44

$\begin{array}{ll}\text { 4.1.2 Runoff variation in Amala upstream } & 47\end{array}$ 
4.1.3 Sediment variation in Amala downstream $\quad 50$

4.1.4 Runoff variation in Amala downstream 53

4.1.5 Sediment Variations with Land covers in Nyangores watershed 55

4.1.6 Runoff variations with land uses in Nyangores watershed 57

4.1.7 Correlations between erosion variables $\quad 59$

4.1.7.1 Rainfall-Runoff relationships $\quad 59$

$\begin{array}{ll}\text { 4.1.7.2 Rainfall-Sediment yield relationships } & 60\end{array}$

4.1.7.3 Runoff with sediment yield relationships $\quad 61$

4.2 WEPP and Erosion 3D models evaluation 62

4.2.1 Water Erosion Prediction Project (WEPP) model 62

4.2.1.1 Runoff observed and simulated using WEPP 62

4.2.1.2 Sediment yield observed and simulated using WEPP 65

4.2.2 Erosion 3D/2D model evaluation 68

4.2.2.1 Runoff simulated and observed using Erosion 3D/2D 68

4.2.2.2 Sediment yield observed and simulated using Erosion 3D 71

4.3 Application of erosion 3D at the watershed scale $\quad 74$

4.3.1 Erosion in the Mara River basin $\quad 74$

4.3.1.1 Erosion variation with land uses $\quad 75$

4.3.1.2 Erosion variation with slope $\quad 78$

Table 4.23 Slope distribution erosion variation in the Mara River basin $\quad 79$

4.3.1.3 Erosion variation with soil types $\quad 80$

$\begin{array}{ll}\text { 4.3.2 Sediment budget in Mara River basin } & 84\end{array}$

4.3.3 Runoff variation in the Mara River basin $\quad 86$

$\begin{array}{ll}\text { 4.3.3.1 Runoff variation with land use/land cover } & 87\end{array}$

4.3.3.2 Runoff variation with soil types $\quad 88$

$\begin{array}{ll}\text { 4.4 WEPP model application at watershed scales } & 90\end{array}$

4.4.1 Sediment yield variation in the Mara River basin 90

4.4.2 Runoff variation in the Mara River basin using WEPP model 91

$\begin{array}{ll}\text { Chapter } 5 & 93\end{array}$

5.0 Summary and Conclusion 93

$\begin{array}{ll}\text { Chapter } 6 & 98\end{array}$

$\begin{array}{ll}\text { 6.0 Recommendations } & 98\end{array}$

$\begin{array}{lr}\text { REFERENCES } & 100\end{array}$

$\begin{array}{ll}\text { APPENDICES } & 105\end{array}$ 


\section{LIST OF TABLES}

\section{TABLE}

PAGE

Table 2.1 Erosion 3D/2D input and output parameters

Table 3.1Major Soils in the Mara River basin and their particle size distribution

Table 3.2 Initial conditions of the Amala upstream, Amala downstream and Nyangores plots

Table 4.1 Extreme event contributions to total sediment yield

Per unit area in the Amala upstream

Table 4.2 Extreme events contribution to the total runoff depth

Table 4.3 Extreme events contribution to total sediment yield

Table 4.4 Standard deviation of runoff coefficient variations with land uses

Table 4.5 Extreme event percentage contribution of sediment to the total sediment yield

Table 4.6 Extreme rainfall events contribution to the total runoff depth during the study period

Table 4.7 Rainfall and runoff correlation at the three experimental sites

Table 4.8 Rainfall andsediment yield correlation at three experimental sites

Table 4.9 Sediment yield and runoff correlation at three experimental sites

Table 4.10 Observed and simulated runoff for different land uses in Amala downstream

Table 4.11 Observed and simulated runoff for different land uses in Amala upstream

Table 4.12 Observed and simulated runoff depth for Nyangores watershed

Table 4.13 Observed and simulated sediment variation on three land uses for Amala downstream 
Table 4.14 Observed and simulated sediment relationships on three land uses for Amala upstream

Table 4.15 Observed and simulated sediment relationships on three land uses for Nyangores

Table 4.16 Observed and simulated runoff depth relationships on three land uses for Amala downstream

Table 4.17 Observed and simulated runoff depth relationships on three land uses for Amala upstream

Table 4.18 Observed and simulated runoff depth relationships on three land uses for Nyangores watershed

Table4.19 Observed and simulated sediment variation on three 72 land uses for Amala downstream

Table 4.20 Observed and simulated relationships on three land uses for Amala upstream

Table 4.21 Observed and simulated relationships on three land uses for Nyangores

Table 4.22 Erosion variation with land uses in the Mara River basin

Table 4.23 Slope distribution erosion variation in the Mara River basin

Table 4.24 Particle size relationship with erosion rate

Table 4.25 Soil type, particle size distribution and mean annual erosion rate in the Mara River basin

Table 4.26 Slope steepness rate of erosion and deposition

Table 4.27 Annual mean runoff distribution in different land uses

Table 4.28 Relationships between soil particle size and runoff depth 88

Table 4.29 Soil types, particle size distribution and runoff depth 89 


\section{LIST OF FIGURES}

FIGURE

PAGE

Figure 3.1 Mara River basin

Figure 3.2 Land use classification in the Mara River basin

Figure 3.3 Soil map of Mara River basin

Figure 3.4 Rainfall variation as recorded in the

Bomet water supply metrological station

Figure 3.5 Runoff plots on bare land and corn covered in the Amala upstream

Figure 3.6 Sediment sampling method using petri dish to determine the sediment load for every rainfall event

Figure 3.7 Runoff plots with grass cover and bare land in the Amala downstream

Figure 3.8 Management file preparation for WEPP model using Ox plow

Figure 3.9 Primary tillage

Figure 3.10 Secondary tillage

Figure 4.1 Sediment variation with land uses in the Amala upstream

Figure 4.2 Runoff depth variation with land uses in Amala upstream

Figure 4.3 Runoff coefficient variations with land uses in Amala upstream

Figure 4.4 Sediment per unit area variation with land uses in Amala downstream watershed

Figure 4.5Variation in sediment concentration with land uses in Amala downstream

Figure 4.6 Runoff depth variation with land uses in Amala downstream

Figure 4.7 Runoff coefficient variation with land uses in Amala downstream

Figure 4.8 Sediment yield (gram per square meter) variations with land use 
Figure 4.10 Erosion distribution in Mara River basin

Figure 4.11Slope distribution map in the Mara River basin

Figure 4.12 Silt particle size content and erosion distribution

Figure 4.13 Sediment budgets in the Mara River basin

Figure 4.14 Spatial distribution of runoff in the Mara River basin

Figure 4.15 Runoff depth-Land use distribution

Figure 4.16 Runoff depth distribution in the Mara River basin 


\section{LIST OF ABBREVIATIONS AND SYMBOLS}

\begin{tabular}{|c|c|}
\hline$\%$ & Percentage \\
\hline${ }^{0} \mathrm{C}$ & degree centigrade \\
\hline $\mathrm{cm}$ & Centimeter \\
\hline ton/ha & ton per hectare \\
\hline hr & Hour \\
\hline I & Intensity \\
\hline $\mathrm{Kg}$ & Kilogram \\
\hline $\mathrm{m}$ & Meter \\
\hline $\mathrm{mm}$ & Millimeter \\
\hline $\mathrm{N}$ & Newton \\
\hline $\mathrm{kg} / \mathrm{m}^{2}$ & Kilogram per square meter \\
\hline WWF & World Wildlife Fund \\
\hline Sec. & Second \\
\hline USDA & United States Department of Agriculture \\
\hline $\mathrm{V}$ & Velocity \\
\hline$g / L$ & gram per litter \\
\hline $\mathrm{g} / \mathrm{m}^{2}$ & gram per square meter \\
\hline
\end{tabular}




\section{Chapter 1}

\subsection{Introduction}

\subsection{Background}

At the global scale, the hazard of soil erosion by water is mostly restricted to the region between latitude $40^{\circ} \mathrm{N}$ and $40^{\circ} \mathrm{S}$ (Hudson 1971). The hazard is related to the large quantity of rainfall amount, intensity and frequency that occur in this region. Although climatic (specifically rainfall) characteristics may serve as general indicators for natural erosion, these alone are not sufficient for assessing total accelerated erosion hazard, which clearly depends on other factors, including the nature of the soil, topographic setting, vegetative cover, and management factors (El-Swaify et al, 1982).

Most regions of the humid tropics of Africa suffer from sever land degradation because of water erosion with its detrimental impact on food and agricultural productivity and production. Greenland (1977), referring to the humid tropics of Africa, stated that the soils of these areas are generally much less productive than they might be, and if more intensive use leads to further loss of fertility and further erosion, the present potential to feed the burgeoning population of these regions will be lost (Cited from El-Swaify, et al. 1982).

In Kenya, where nearly 70 percent of the country consists of arid lowlands utilized as rangelands, erosion problems prevail in the highlands where lands are cultivated intensively, the rainfall is sufficiently heavy, and topography is steep (Ahn 1977). Soil 
erosion that results from water becomes the bottleneck problem of the country. Because of an increase in population and poor management of cultivated land as well as overgrazing, erosion becomes severe in the country. According to El Swaify et al. (1982), erosion rate up to $200 \mathrm{ton} / \mathrm{ha} / \mathrm{yr}$ has been noted in Kenya as a result of increased in grazing.

The trans-boundary Mara River basin lies across Kenya and Tanzania and covers about $13,834 \mathrm{~km}^{2}$ areas. It traverses the internationally acclaimed Maasai Mara Game Reserve in Kenya and the Serengeti National Park in Tanzania. The basin receives a bimodal rainfall with the mean values varying from $1400 \mathrm{~mm} / \mathrm{yr}$ on the highlands to $600 \mathrm{~mm} / \mathrm{yr}$ on the lowlands (Mutie et. al., 2006). The basin encloses a mosaic of land-use types with natural forests, large mechanized and small holder subsistence cultivated lands, grazing lands, open savanna and some wetlands just before the river discharges into Lake Victoria at Musoma, Tanzania.

As a result of population pressure, significant land-use changes have been occurred that adversely affect the hydrology and ecosystem of the basin. According to Mango (2010) land-use/land cover change significantly impact the water flux in the upper Mara River. Forests and savannah grasslands have been cleared and turned into agricultural lands (cf. Mati et al. 2005). Moreover; charcoal burning, overgrazing, and expansion of agricultural activities exposed the land for degradation. The area under cultivation in the Amala subcatchment increased from less than $20 \%$ in 1960 to more than $51 \%$ in 1991 ; this is partly 
the result of rapid population growth, the number of households increased by $13 \%$ in the upper catchments (Mati et al., 2005).

The modification and mismanagement of land for various uses usually lead to changes in rainfall-runoff characteristics of the basin which consequently affects upland productivity and the river hydrological and sediment regimes. Major environmental changes resulting from the basin surface modification observed in Mara River basin include high peak stream flows, reduced base flows, enlarged river channel, and sedimentation along the river bed (Mutie, et al. 2006).

\subsection{Statement of the problem}

Despite the aforementioned valuable contributions of the basin to the quality and quantity of the Mara water resources and downstream reservoirs, no or little attention was given to the basin. However, for sustainable utilization of the Mara fresh water resource, and for protection of reservoirs from 'sediment danger' as well as for maintaining the productivity of the basin, sound extensive conservation and corrective measures may need to be designed on such potential source areas. Within this context, the current and potential hydrological and erosion responses of the area may need to be assessed and quantified at various scales.

Soil erosion and surface runoff processes can be viewed at various scale levels. Depending upon the research objectives and the nature and types of models intended to 
be used; such processes can be viewed at small plots and test plots, at individual field or slopes, and at catchments area of small streams or at entire river basin scale (Wickenkamp et al., 2000). In the Mara River basin, little research has been done and little or no data are available to study the effect of different factors on soil erosion and to quantify the rate of current erosion. Without such information, reduction of soil erosion to the tolerable rate and designing of sound conservation structures would become difficult. As a result data will need to be collected at different scales (field and watershed), and employ various approaches (field experiment, lab analysis and modeling). Results from this study will help quantify the current rate of erosion, identify erosion hot-spot areas and also evaluate the effect of different factors on the erosive processes.

\subsection{Justification of the Study}

Different studies have been conducted to explain the processes of runoff and erosion, identify the major factors influencing the processes, and also to develop models suitable to quantify the processes. Application and adaptation of these models and methods to the Mara River basin to quantify the upland and watershed runoff and sediment yield will be a great contribution to the on-going effort to improve the water quality of the river.

Many available hydrological and erosion models are different in terms of scale (temporal and spatial), formulation and assumptions, input data requirements, outputs and level of 
accuracy. Nearly all models have limitations in their applications, and use of models for a specific watershed like Mara River basin requires understanding of the model and careful selection. Another major problem of sediment modeling in the Mara arises from little or inadequate sediment data. Therefore selection of models that may need little input data and applicable at various scales is a prerequisite. This has necessitated the use of models like the EROSION 3D which was developed to create an easy-to-use tool for erosion prediction in soil and water conservation planning assessment and that need few input parameters (Schmidt et al., 1999). However, with such limited available data, a watershed scale modeling and entirely dependent on the model output may not be wise. In order to evaluate such model and assess the effect of different land uses on erosion and sediment yield, field data on sediment and runoff generation is essential.

\subsection{Research questions}

Considering the available problems and knowledge gap in the Mara River basin, this study was proposed to address the following research questions:

1. How does soil loss and runoff vary as a function of land cover and soil properties in different areas of the Mara River?

2. Where are the erosion hazard and sediment potential areas located in the Mara river basin and what factors affect their distributions?

3. How do the Water Erosion Prediction Project (WEPP) and Erosion 3D models perform for the Mara River basin? 
4. How are the various erosion and runoff variables interrelated in the Mara River basin? and,

5. How do the erosion and runoff responses vary ai field and watershed scales in the Mara River basin?

\subsection{Objectives}

In order to understand the sediment detachment and transport as well as the hydrological responses of the different land uses, soil and slope steepness in the Mara River basin, and to address the above research questions, the following specific objectives were proposed:

1. Evaluate the effects of land cover change on runoff and sediment yield using runoff plots data and evaluation of relationships between different erosion variables

2. Evaluate the Water Erosion Prediction model (WEPP) and Erosion 3D models using data at field scale and;

3. Identify potential sediment source areas and estimate the yields of sediments; and evaluate effect of land cover changes on sediment yield and runoff fluxes at watershed scale. 
Chapter 2

\subsection{Literature Review}

Many planning and management theories and formulas have been developed in order to estimate and reduce soil loss from basin and, as a result, sediment transported to hydrological networks. In order to plan conservation strategies and for controlling the effect of land management techniques, sediment transported to hydrological networks may need to be estimated using models. However before applying these models, the process of erosion and runoff may need to be understood and various factors affecting erosion at different scale may need to be quantified.

\subsection{Soil erosion and land degradation}

Here the various processes and types of soil erosion and their causes are discussed. The information is important for the understanding of the processes simulated by Erosion 3D and WEPP models and also use for understanding of the process of soil erosion for the plot scale field research.

\subsubsection{Land degradation}

Land degradation is the reduction in the capability of the land to produce benefits from a particular land use under a specific form of land management as a result of physical, chemical or biological factors (Hurni et al. 1996). This definition of land degradation includes the degradation of soil, fauna and flora, water, climate, and losses because of urban development; thus, it may impact entire ecoregions and is a broader concept than 
soil degradation (Hurni et al. 1996). Consequently, soil degradation is a process which lowers the current and / or the potential capability of the soil to produce goods or services as a result of physical, chemical or biological causes.

Degradation that leads to change in chemical properties of a soil which affect its productivity, such as salinity, is considered to be chemical degradation. Similarly degradation that happens because of compaction, soil erosion or other physical change in soil properties is called physical degradation, and degradation that brings biological change in soil properties such as reduction in organic matter is called biological degradation. Soil erosion may lead to physical degradation by removing the soil particle from a soil mass, and to biological degradation by removing organic matter and nutrient of a soil with the soil mass, and chemical degradation by removing the chemical property of a soil. Because of different definitions and terminology, variation in the available statistics on the extent and rate of land degradation also exists (Eswaran, et al. 2001). According to Dregne and Chou (1994), in Africa $73 \%$ of the total land surface is degraded because of physical, chemical and biological causes.

\subsubsection{Factors influencing soil erosion}

Erosion is a two-phase process that includes the detachment and transport of soil particles caused by the action of running water, rainfall and wind. Climate, geology and topography are considered to be the most important influences on erosion, provided that soil type and vegetation cover depend upon them and are interrelated to each other 
(Selby, 2000). As a result, a complex web of relationships between factors involved in erosion processes evolves. Precipitation, temperature and wind are considered to be the major climatic factors influencing surface flow and erosion, whereas precipitation is the most important. Raindrops disintegrate soil aggregates as a result of raindrop impact; minor lateral displacement of soil particle that results from the lateral forces of raindrop; splashing of soil particles into the air; and selection or sorting of soil particles by raindrop impact. The resistance of the soil and the amount, intensity, and duration of the rainfall control the extent of splash erosion (Defersha, 2004). As a consequence it can be stated that low rainfall intensity with long duration and high rainfall may cause no or slight erosion, whereas a short and intense rainy event may lead to heavy erosion damage (Cf Strahm, 2007). Soil steepness and slope length have significant effect on erosion processes. On steep slopes more splashed sediment may be moved down than on gentle ones and also there will be more surface flow and its velocity will be faster. Defersha (2004) observed a significant effect of slope steepness on soil erosion and runoff for three soils in Alemaya watershed, Ethiopia. The slope length has a similar impact. On long slopes higher surface flow velocity is possible and rills can develop more readily.

According to Selby (2000), vegetation has impact on the amount and velocity of runoff which in turn may reduce the erosivity of the erosive agents (rainfall and runoff) that has impact on the transport as well as detachment capacity of flow. Interception of rainfall by the vegetation canopy reduce the impact of raindrops by reducing their kinetic energy; decreasing of surface flow velocity; increased soil strength, and increase in porosity 
because of root effects are the major effects of vegetation on erosion. Soil erodibility is not a fundamental property and is difficult to measure and no universal method of measurement has been developed yet. Erodibility depends on many factors, which can be divided into two groups: the actual physical conditions of the soil and the impact of human activities (Selby, 2000).

\subsubsection{Soil erosion processes}

The type of soil erosion by water may be classified in to four types: splash erosion, interrill erosion, rill erosion, and gully erosion. The impact of raindrops leads to rain splash which detaches soil particles and removes them for several centimeters or meters through the air. Afterwards soil particles are ready for transport by interrill flow. Interrill erosion is erosion between rills. Detached soil particles are washed away by interrill flow (interrill erosion). Simultaneously surface flow, overland flow, picks up additional soil particles. Rill erosion develops from interrill and forms channels up to $50 \mathrm{~cm}$ depth. Finally, gully erosion may occur as a result of rill erosion, even though it is not the only reason for rill formation. Rill erosion generates channels deeper than $50 \mathrm{~cm}$, which is

difficult to pass over with ordinary farm tillage equipment (e.g., river beds can be considered as permanent gullies). 


\subsection{Soil erosion Experiment}

The erosion phenomenon is completely or partially simulated in the field or in the laboratory in order to investigate erosion mechanisms systematically (De Ploey and Gabriels, 1980). It is presumed that the experimenter can control at least one important erosion factor so that its role in the total phenomenon can be tested. At the field scale, erosion research can be conducted using natural rainfall or an artificial rainfall simulator. Soil erosion data can be obtained more rapidly and effectively by using simulated rainfall than by relying on natural rainfall. According to Meyer (1993), the major advantages of rainfall simulator research are: it is more controlled, more rapid, more efficient, and more adaptable than natural rainfall. However, it is difficult to simulate the natural rainfall properties such as rainfall velocity, raindrop size, rainfall uniformity, raindrop shape and other important properties of a rainfall.

\subsection{Runoff plots in soil erosion experiment}

Evaluating the effects of different soil and crop management or land use practices on runoff generation and/or soil loss is largely derived from soil erosion or runoff plot experiments. Runoff plots can be used for comparative studies, for example to test, or demonstrate, or get an approximate indication of the effects of runoff or erosion of a simple comparison such as with and without surface mulch, or with and without ground cover. Another valid use is to obtain data which are to be used to construct, or to evaluate model or equation to predict runoff or soil loss (Hudson, 1993). 
The runoff and sediment sample can be taken automatically or manually. If runoff and soil loss are sampled manually, then their accuracy depends on the sampling procedures adopted and the diligence of the field staff. A laboratory in Kenya compared the manual sampling accuracy of field staff in charge of erosion plots at the Steep Lands Research Station of the University of Nairobi, the results indicated that the runoff volume was generally slightly under-estimated, but sampling accuracy was acceptable for manual sampling; the mean square error was $5.6 \%$, with a range of $3.6-6.7 \%$ and marked differences between the performances of the field staff were not observed, however, the accuracy of soil loss measurements varied significantly (Zobisch, et al., 1996). According to the authors, the mean square sampling errors ranged from 4.7 to $83.0 \%$, with an average of $41.3 \%$, which is unacceptably poor accuracy. On the basis of their research results, Zobisch, et al. (1996) recommended that to ensure adequate sampling performance, appropriate sampling methods should be designed, training of field staff in sampling techniques should be provided, and regular performance testing should be implemented.

\subsection{Modeling Soil Erosion}

Three types of models can be distinguished. There are black, grey and white models. A black model (empirical and statistical) does not consider any process operating on an input value. It constitutes exclusively a mathematical relationship between the input data and the output values. A white box model, in contrast, considers individual process and parameters can be calibrated individually. They are represented by deterministic, physical 
or process oriented models. Grey box models are hybrid forms of the former two types (Morgan, 1994).

According to Hebel et al. (2005), besides the basic models, a more differentiated classification is possible: Dynamic models evaluate processes depending on progressive time steps; Empirical models are derived from on observed quantitative relations of variables without any regard on the processes within the system under examination; Stochastic models are based on a probability distribution. Deterministic models do not consider stochastic variables and are constructed from relations determined by logical functions such as chemical reaction. Process based models are based on known physical processes or mechanisms; typical example is Erosion 3D and WEPP models.

\subsubsection{Background of Erosion 3D and Erosion 2D}

\subsubsection{Overview}

Erosion 3D is an advance over Erosion 2D, which, was developed from 1988 to 1994 to serve the following applications (Von Werner, 2006): Calculation of erosion and deposition of extreme rainfall events; estimation of cumulative erosion for a long time monitoring; impact simulation of land consolidation measurements; impact simulation of different cultivation techniques such as crop type, land management, land cover and crop cycles; impact estimation of soil characteristics such as soil moisture and surface roughness; and estimation of pollutant transport attached to soil particles. Erosion 3D basically requires the same input parameters as Erosion 2D, and the input and output 
parameters of the model are summarized in Table 2.1 below. The input parameters can be assigned to three main groups: relief parameters, soil parameters, and climate parameters.

Table 2.1 Erosion 3D/2D input and output parameters

\begin{tabular}{|c|c|}
\hline Input parameters & Output parameters \\
\hline Relief parameters: Digital elevation data & Runoff \\
\hline Surface and soil parameters: & Sediment discharge \\
\hline - Texture, Bulk density, Organic matter & Grain size distribution of the \\
\hline $\begin{array}{l}\text { content, Initial soil moisture Surface } \\
\text { roughness, Resistance to erosion_(critical }\end{array}$ & transported sediment \\
\hline Momentum flux). & Rate of Erosion/deposition \\
\hline $\begin{array}{l}\text { - Canopy cover, infiltration correction factor } \\
\text { - Precipitation parameters: }\end{array}$ & Net erosion \\
\hline
\end{tabular}

Erosion 3D uses three basic models: the digital slope and surface flow model generated based on the DTM; the erosion and deposition model; and the infiltration model. Below the program algorithms and the available user applications are presented.

\subsubsection{Physical modeling algorithms (Slope and surface flow model)}

Digital Elevation Model consist only of raster cells with one elevation value usually in the center of the horizontally oriented cell, and it probably has irregularities that must be processed in respect of slope and pits. 
Pits and holes

Erosion 3D automatically generates a water distribution network. The algorithms applied, however, only work properly after eliminating existing flat areas and pits because every cell requires a defined outflow direction based on the descent slope from the neighboring eight cells (Strahm, 2007). If there is no affiliated cell with a lower value, the value of the cell under examination is raised by a definable unit until it exceeds the surrounding lowest cell value.

\section{Topography}

Slopes are calculated with the help of affiliated cells in EROSION 3D. Three different algorithms are provided by the model. All of them lead to a more smoothed topography with the help of four or eight neighboring cells. When calculating slopes with four neighbors (normal vector) two vectors $\mathrm{A}$ and $\mathrm{B}$, which run parallel the spatial plain of the examined raster element from east to west, respectively south to north, are defined (considering each difference in $z$ direction) (Strahm, 2007). The vector product of these two vectors leads to the normal vector $\mathrm{N}$. vector $\mathrm{N}$ is used to calculate the slope angle in respect of an orthographic vector placed on the horizontal raster element plane. With the length of the normal vector, the area of the rhomboid constructed with vectors $A$ and $B$ is assessed. Slopes can alternatively be calculated with eight neighbors. In this case, the mean difference in $\mathrm{z}$ direction for east-west and south-north orientation is evaluated with three elevation values at a time. Individually the alternative eight neighbors weighted can be chosen to give more attention to the main axis directions (Strahm, 2007). 


\section{Hydrology}

Flow paths are calculated automatically by EROSION 3D. Here two types of calculation algorithms are available. The D8-algorithm identifies the difference in $\mathrm{z}$ (altitudinal difference) between the examined cell element and its lower placed elements. Diagonally placed cell elevation values are afterwards divided with $\sqrt{2}$ because of their increased distance. The neighboring element with the maximum difference in $\mathrm{z}$ will now receive all surface flow (von Werner, 2006).

Another option is the FD8-algorithm which assumes surface flows are distributed to all lower raster elements proportionally.

The D8-algorithm is useful to get a quick impression of the general flow direction. The D-8 algorithm often does not appropriately represent the reality and is not very helpful when modeling overland flows and slope erosion. In this case, the FD8-algorithm is required. In receiving streams (flow accumulation system) the D8-algorithm (one cell element drains only towards the lowest neighboring raster cell) must be chosen because otherwise an unnatural flow distribution out of the stream takes place. The D8-algorithm generally produces more erosion than FD8-algorithm. The former leads to increased flow accumulation in the outlets and as in extreme erosion rates. Furthermore, less deposition can be stated when using D8-algorithm (Von Werner, 2006). 
2.4.1.3 Erosion and deposition model (Erosion 3D)

In the Erosion 3D model, erosion is simulated in two processes, it estimates detachment of soil particles by rainfall and runoff and their transport by flowing water.

\section{Detachment of particles}

In Erosion 3D, particles detachment occurs if the sum of the momentum fluxes exerted by rainfall and overland flow exceeds a critical momentum flux or soil resistance $\varphi_{\text {crit }}$. Detachment of soil particle takes place by the power resulting from surface flow (momentum flux exerted by flow $\varphi_{q}$ ) and raindrops (momentum flux exerted by droplets $\left.\varphi_{\mathrm{r}}\right)$ acting with the power attaching the particles to the soil (cohesion, adhesion, friction and gravity) (Schob et al., 2006).

$$
\mathrm{E}=\left(\varphi_{\mathrm{q}}+\varphi_{\mathrm{r}}\right) / \varphi_{\text {crit }}
$$

With $E=0 \quad$ if $\quad \varphi_{\mathrm{q}}=0$

Where

$\mathrm{E}=$ Erosion $(\mathrm{E}>1)$ or deposition $(\mathrm{E}<1)$

$\varphi_{\mathrm{q}}=$ Momentum flux exerted by flow $\left(\mathrm{kg} \mathrm{m}^{-1} \mathrm{~s}^{-2}\right)$

$\varphi_{\mathrm{r}}=$ Momentum flux exerted by raindrop

$\varphi_{\text {crit }}=$ Critical momentum flux to initiate soil erosion $\left(\mathrm{kg} \mathrm{m}^{-1} \mathrm{~s}^{-2}\right)$ 
The momentum flux exerted by flow is defined by the equation:

$$
\varphi_{\mathrm{q}}=\left(\mathrm{w}_{\mathrm{q}} \mathrm{v}_{\mathrm{q}}\right) / \Delta \mathrm{x}
$$

With

$$
w_{q}=q \rho_{q}\left[\left(r_{\theta}-i\right) \Delta x+q_{i n}\right] \rho_{q}
$$

And

$$
\mathrm{v}_{\mathrm{q}}=\mathrm{s}^{1 / 2} \mathrm{~h}^{2 / 3} / \mathrm{n}
$$

With

$$
\mathrm{h}=\left(\mathrm{qn} / \mathrm{s}^{1 / 2}\right)^{2 / 5}
$$

Where

$$
\begin{aligned}
& \varphi_{\mathrm{q}}=\text { Momentum flux of flow }\left(\mathrm{kgm}^{-1} \mathrm{~s}^{-2}\right) \\
& \mathrm{w}_{\mathrm{q}}=\text { Mass rate of flow }\left(\mathrm{kgm}^{-1} \mathrm{~s}^{-1}\right) \\
& \mathrm{v}_{\mathrm{q}}=\text { Mean flow velocity }\left(\mathrm{ms}^{-1}\right) \\
& \Delta \mathrm{x}=\text { Length of slope segment }(\mathrm{m}) \\
& \rho_{\mathrm{q}}=\text { Fluid density }\left(\mathrm{kg} \mathrm{m}^{-3}\right) \\
& \mathrm{r}_{\theta}=\text { Effective rainfall intensity on slope segment }\left(\mathrm{ms}^{-1}\right) \\
& \mathrm{i}=\text { Infiltration rate }\left(\mathrm{ms}^{-1}\right) \\
& \mathrm{q}=\text { Discharge of actual segment }\left(\mathrm{m}^{2} \mathrm{~m}^{-1} \mathrm{~s}^{-1}\right) \\
& \mathrm{q}_{\mathrm{in}}=\text { Inflow from upslope segment }\left(\mathrm{m}^{2} \mathrm{~m}^{-1} \mathrm{~s}^{-1}\right) \\
& \mathrm{h}=\text { Mean flow depth }(\mathrm{m}) \\
& \mathrm{n}=\text { Manning hydraulic roughness }\left(\mathrm{s} \mathrm{m}^{-1 / 2}\right) \\
& \mathrm{S}=\text { Slope (m/m) }
\end{aligned}
$$


In Erosion 3D, the rainfall intensity is expressed in terms of its momentum flux (momentum divided by unit time):

$$
\varphi_{\mathrm{r}}=\mathrm{r}_{\Theta} \rho_{\mathrm{r}} \mathrm{v}_{\mathrm{r}} \sin \Theta\left(1-\mathrm{A}_{\text {leaf }} / \mathrm{A}\right)
$$

With

$$
r_{\theta}=r \cos \theta
$$

Where

$r=$ Rainfall intensity $(\mathrm{m} / \mathrm{s})$

$\varphi_{\mathrm{r}}=$ Momentum flux exerted by falling droplets $\left(\mathrm{Kg} \mathrm{m}^{-1} \mathrm{~s}^{-1}\right)$

$r_{\theta}=$ Effective rainfall intensity related to slope inclination $(\mathrm{m} / \mathrm{s})$

$\rho_{\mathrm{r}}=$ Fluid density of rainfall $\left(\mathrm{Kg} / \mathrm{m}^{3}\right)$

$v_{r}=$ Mean fall velocity of droplets $(\mathrm{m} / \mathrm{s})$

$A_{\text {leaf }}=$ Portion of ground covered by plants or crop residue $\left(\mathrm{m}^{2}\right)$

$\mathrm{A}=$ Total area $\left(\mathrm{m}^{2}\right)$

$\theta=$ Slope in degree

Mean raindrop velocity only can be measured with substantial technical efforts. As a consequence an estimation procedure based on the work of is applied. Velocity is calculated with:

$$
\mathrm{v}_{\mathrm{r}}=4.5 \mathrm{r}^{0.12}
$$

Where

$\mathrm{r}=$ Rainfall intensity $(\mathrm{m} / \mathrm{s})$. 
Transportation and deposition

After the detachment, soil particles are transported in the flowing water. The transport capacity calculation in Erosion $3 \mathrm{D} / 2 \mathrm{D}$ are based on the idea that the maximum sediment concentration $\mathrm{C}_{\max }$ of the overland flow is determined by the equilibrium between the downward directed momentum flux of the settling sediment particles, and a counteracting upward momentum flux component exerted by turbulence:

$$
\varphi_{\mathrm{p}, \mathrm{crit}}=\varphi_{\mathrm{q}, \mathrm{vert}}
$$

With

$$
\begin{aligned}
& \varphi_{\mathrm{p}, \mathrm{crit}}=\mathrm{c}_{\max } \rho_{\mathrm{p}} \mathrm{Av}_{\mathrm{p}}{ }^{2} \\
& \varphi_{\text {ver }}=\varphi_{\mathrm{q}} \varphi_{\mathrm{r}} / \mathrm{k}
\end{aligned}
$$

Where

$\varphi_{\mathrm{p}, \text { crit }}=$ Momentum flux below which falling sediment particles cannot be held in suspension $\left(\mathrm{kgm}^{-1} \mathrm{~s}^{-2}\right)$

$\varphi_{\mathrm{q}, \text { vert }}=$ Vertical momentum flux component exerted by flow $\left(\mathrm{kg} \mathrm{m}^{-1} \mathrm{~s}^{-2}\right)$

$\varphi_{\mathrm{r}}=$ Momentum flux of rainfall $\left(\mathrm{kg} \mathrm{m}^{-1} \mathrm{~s}^{-2}\right)$

$\varphi_{p}=$ Momentum flux of flow $\left(\mathrm{kg} \mathrm{m}^{-1} \mathrm{~s}^{-2}\right)$

$\mathrm{k}=0.001=$ Coefficient defining the effective upward component of total momentum flux

$\mathrm{C}_{\max }=$ Maximum sediment concentration in flow $\left(\mathrm{m}^{3} \mathrm{~m}^{-3}\right)$

$\rho_{p}=$ Particle density $\left(\mathrm{kg} \mathrm{m}^{-2}\right)$

$A=$ Area of slope segment $\left(\mathrm{m}^{2}\right)$ 
$v_{p}=$ Settling velocity of soil particles in stagnant fluid $\left(\mathrm{m} \mathrm{s}^{-1}\right)$, calculated from Stokes' law

Rearranging Eq. 2.9 and Eq. 2.11 and solving for the maximum sediment concentration yields the transport capacity $\mathrm{q}_{\mathrm{s}, \max }$ as:

$$
\mathrm{q}_{\mathrm{s}, \max }=\mathrm{c}_{\max } \rho_{\mathrm{p}} \mathrm{q}
$$

Where

$\mathrm{q}_{\mathrm{s}, \max }=$ Transport capacity $\left(\mathrm{kg} \mathrm{m}^{-1} \mathrm{~s}^{-1}\right)$ and

$\mathrm{q}=$ Volume rate of flow $\left(\mathrm{m}^{3} \mathrm{~m}^{-1} \mathrm{~s}^{-1}\right)$

Infiltration model

In Erosion 3D/2D, infiltration is calculated on the basis of a formula developed using the approach of Green \& Ampt (1911). It is assumed that the water infiltrates cob like and fills up the whole pore volume. Mathematically, the infiltration rate is calculated with the help of the Darcy Equation which assesses vertical hydrological flows in soils.

$$
\mathrm{i}=-\mathrm{k}_{2} *\left(\psi_{\mathrm{m}}+\psi_{\mathrm{g}}\right) / \mathrm{xf}(\mathrm{t})
$$

Where

$\mathrm{i}=$ Infiltration $\operatorname{rate}(\mathrm{L} / \mathrm{T})$

$\mathrm{k}_{2}=$ Hydraulic conductivity $(\mathrm{L} / \mathrm{T})$

$\psi_{\mathrm{m}}=$ Matric potential $(\mathrm{L})$

$\psi_{\mathrm{g}}=$ Gravitational potential (L)

$x f(t)=$ Penetration of moisture front $(L)$ subject to time $t$ 
Sensitivity of Erosion 3D

According to Von Werner et al (2005), the most sensitive input parameters of Erosion 3D regarding soil erosion are mainly soil factors such as initial soil moisture or content of organic C. The intensity of rainfall and the topography in this list, however, do have relatively low effects on soil erosion simulation results. Below the seven most sensitive input parameters of Erosion 3D are listed in a relative order: Initial soil moisture, content of organic $\mathrm{C}$, rainfall intensity, erodibility, roughness, slope length, slope angle, respectively.

\subsubsection{Water Erosion Prediction Project (WEPP) model}

The Water Erosion Prediction Project (WEPP) model is a process-oriented, continuous simulation, erosion prediction model. It is applicable to small watersheds/field-sized and can simulate small profiles (USLE types) up to large fields. It mimics the natural processes that are important in soil erosion. The WEPP model had been evaluated and applied in Anjani watershed, Ethiopia, East Africa, and according to Zeleke (2000), the model performed well, but it under-predicted large events and over-predicts for low rainfall events. 


\subsubsection{Hydrology}

Similar to Erosion 3D/2D the Green-Ampt approach is used in the WEPP model in order to simulate the temporal changes in infiltration rate during the rainstorm (Schroder, 2000). The differential form of this equation for soil matrix of infinite depth is:

$$
\mathrm{i}=\mathrm{k}_{\mathrm{e}}+\left(1+\left(\left(\phi-\Theta_{0}\right) \psi_{\mathrm{c}}\right) / \mathrm{l}\right)
$$

Where

$$
\begin{aligned}
& \mathrm{i}=\text { Actual infiltration rate }\left(\mathrm{m} \mathrm{s}^{-1}\right) \\
& \mathrm{k}_{\mathrm{e}}=\text { Effective hydraulic conductivity of the wetted zone }\left(\mathrm{m} \mathrm{s}^{-1}\right) \\
& \Theta_{0}=\text { Initial saturation }\left(\mathrm{m}^{3} \mathrm{~m}^{-3}\right) \\
& \phi=\text { Effective porosity }\left(\mathrm{m}^{3} \mathrm{~m}^{-3}\right) \\
& \psi_{\mathrm{c}}=\text { Effective capillary tension or wetting front suction potential }(\mathrm{m}) \\
& 1=\text { Cumulative infiltration }(\mathrm{m})
\end{aligned}
$$

The above equation describes the exponential approach of the actual infiltration rate (i) to the hydraulic conductivity when actual infiltration rate approximates infinity. According to the most important assumption of this approach are the piston-like entry of the water into the soil and a sharply defined wetting front which separates the fully saturated (above) and unsaturated (below) zones. The driving parameters of the Green-Ampt model are the wetting front suction potential $\varphi_{c}$, the soil moisture deficit $\left(\phi-\Theta_{0}\right)$, and the effective saturated conductivity $k_{\mathrm{e}}$ 
Surface runoff routing

If the potential surface storage depression storage is completely satisfied, the positive difference between the net rainfali intensity at the ground surface and the infiltration rate becomes the input to the overland flow calculation (Schroder, 2000). The basic equations which describe the movement of a water wave through arbitrarily shaped cross-sections along an inclined surface are simplified forms of the Saint-Vernant equations which are based on the laws of mass and momentum conservation:

$$
\frac{\partial A}{\partial t}+\frac{\partial Q}{\partial x}=r(t)-i(t)=q(x, t)
$$

And

$$
\mathrm{Q}=\propto \mathrm{PR}^{\mathrm{m}-1}
$$

With

$$
\propto=C \sqrt{S}
$$

Where

$$
\begin{aligned}
& A=\text { Cross-sectional area }\left(\mathrm{m}^{2}\right) \\
& \mathrm{t}=\text { Time }(\mathrm{s}) \\
& \mathrm{Q}=\text { Discharge }\left(\mathrm{m}^{3} / \mathrm{s}\right) \\
& \mathrm{x}=\text { Down slope distance }(\mathrm{m}) \\
& \mathrm{r}=\text { rainfall intensity }\left(\mathrm{m} \mathrm{s}^{-1}\right)
\end{aligned}
$$




$$
\begin{aligned}
& \mathrm{i}=\text { Local infiltration rate }\left(\mathrm{m} \mathrm{s}^{-1}\right) \\
& \mathrm{q}=\text { Lateral inflow rate }\left(\mathrm{m} \mathrm{s}^{-1}\right) \\
& \mathrm{R}=\text { Hydraulic radius }(\mathrm{m}) \\
& \mathrm{P}=\text { Wetted perimeter }(\mathrm{m}) \\
& \mathrm{m}=\text { Depth }- \text { discharge exponent Chezy: } \mathrm{m}=3 / 2, \text { Manning: } \mathrm{m}=5 / 3 \\
& \alpha=\text { Depth-discharge coefficient }\left(\mathrm{m}^{1 / 2} \mathrm{~s}^{-1}\right) \\
& \mathrm{s}=\text { Average slope }(\mathrm{m} / \mathrm{m})
\end{aligned}
$$

In WEPP, the overland flow is conceptualized as plane runoff which means that $A$ is substituted by the average flow depth $\mathrm{h}$ (expressed in $\mathrm{m}$ ). Equations (2.15) and (2.16) are solved analytically by the methods of characteristics which require the rewriting of these equations as differential equations on characteristics curve on the $x-t$ plane (Flanagan and Nearing, 1995):

$$
\frac{d h}{d t}=v(t)
$$

And

$$
\frac{d x}{d t}=\alpha m h(t)^{m-1}
$$

Where $\quad h=$ Flow depth $(m)$

$$
\mathrm{v}=\text { Runoff or rainfall excess }\left(\mathrm{m} \mathrm{s}^{-1}\right)
$$


These equations are solved together with the infiltration calculations by using a RunggeKutta iteration scheme with as spatial resolution of one hundredth of the total hill slope length and a time step of one minute.

\subsubsection{Erosion and deposition}

The movement of the sediment along the hill slope is described on the basis of the steadystate sediment continuity equation which is applied flow conditions (Flanagan and Livingston, 1995):

$$
\frac{d G}{d x}=D_{i}+D_{r}
$$

Where

$$
\begin{aligned}
& \mathrm{G}=\text { Sediment load }\left(\mathrm{kg} \mathrm{s}^{-1} \mathrm{~m}^{-1}\right), \mathrm{x}=\text { Distance down slope }(\mathrm{m}), \mathrm{D}_{\mathrm{r}}=\text { Rill } \\
& \text { erosion rate }\left(\mathrm{kg} \mathrm{s}^{-1} \mathrm{~m}^{-1}\right), \mathrm{Di}=\text { Interrill erosion rate }\left(\mathrm{kg} \mathrm{s}^{-1} \mathrm{~m}^{-1}\right)
\end{aligned}
$$

The rill and interrill erosion rates are determined from the following relationships (Huang et al., 1996):

$$
\mathrm{D}_{\mathrm{i}}=\mathrm{K}_{\mathrm{i}} \mathrm{I}_{\mathrm{e}} \sigma_{\mathrm{ir}} \mathrm{SDR}_{\mathrm{RR}} \mathrm{F}_{\text {nozzle }}\left(\mathrm{R}_{\mathrm{s}} / \mathrm{w}\right) \quad \text { (interrill areas) }
$$

And

$$
\mathrm{D}_{\mathrm{c}}=\mathrm{K}_{\mathrm{c}}\left(\tau_{\mathrm{f}}-\tau_{\mathrm{c}}\right) \quad \text { (rill areas) }
$$

with

$$
D_{i}=D_{c}\left(1-G / T_{c}\right) \text { if } \tau_{f}, \tau_{c} \text { and } G>T_{c} \quad \text { (Erosion) }
$$


And

$$
D_{\mathrm{f}}=\beta \mathrm{v}_{\mathrm{f}} / \mathrm{q}\left(\mathrm{T}_{\mathrm{c}}-\mathrm{G}\right) \quad \text { if } \mathrm{G} \geq \mathrm{T}_{\mathrm{c}} \quad \text { (Deposition) }
$$

Where

$$
\begin{aligned}
& \mathrm{D}_{\mathrm{i}}=\text { Interrill sediment delivery rate to rill }\left(\mathrm{kg} \mathrm{s}^{-1} \mathrm{~m}^{-1}\right) \\
& \mathrm{K}_{\mathrm{i}}=\text { Interrill soil erodibility parameter }\left(\mathrm{kg} \mathrm{s}^{-1} \mathrm{~m}^{-4}\right) \\
& \mathrm{I}_{\mathrm{e}}=\text { Effective rainfall intensity }\left(\mathrm{m} \mathrm{s}^{-1}\right) \\
& \sigma_{\mathrm{ir}}=\text { Interrill runoff rate }\left(\mathrm{m} \mathrm{s}^{-1}\right) \\
& \mathrm{SDR}_{\mathrm{RR}}=\text { Sediment delivery ratio }
\end{aligned}
$$

$F_{\text {nozzle }}=$ Adjustment factor to account for sprinkler irrigation nozzle energy variation

$$
\begin{aligned}
& R_{\mathrm{s}}=\text { Spacing of rills }(\mathrm{m}) \\
& \mathrm{W}=\text { Rill width }(\mathrm{m}) \\
& \mathrm{D}_{\mathrm{c}}=\text { Detachment capacity in a rill }\left(\mathrm{kg} \mathrm{s}^{-1} \mathrm{~m}^{-2}\right) \\
& \mathrm{K}_{\mathrm{r}}=\text { Rill soil erodibility parameter }\left(\mathrm{sm}^{-1}\right) \\
& \tau_{\mathrm{f}}=\text { Flow shear stress }(\mathrm{Pa}) \\
& \tau_{\mathrm{c}}=\text { Critical shear stress to initiate particle detachment }(\mathrm{Pa}) \\
& \mathrm{D}_{\mathrm{f}}=\text { Net detachment or deposition }\left(\mathrm{kg} \mathrm{s}^{-1} \mathrm{~m}^{2}\right)
\end{aligned}
$$


$\mathrm{G}=$ Sediment load $\left(\mathrm{kg} \mathrm{s}^{-1} \mathrm{~m}^{2}\right)$
$\mathrm{T}_{\mathrm{c}}=$ Transport capacity $\left(\mathrm{kg} \mathrm{s}^{-1} \mathrm{~m}^{-1}\right)\left(=\mathrm{G}_{\max }\right)$

$\beta=0.5=$ Raindrop-induced turbulence coefficient

$v_{\mathrm{f}}=$ Effective fall velocity for sediment particles $\left(\mathrm{m} \mathrm{s}^{-1}\right)$, calculated by Stokes' Law

$\mathrm{q}=$ Discharge per unit width $\left(\mathrm{m}^{2} \mathrm{~s}^{-1}\right)$ 
Chapter 3

3.0 Material and Methods

3.1 Description of the study area

3.1.1 Location

The Mara River basin covers $13,834 \mathrm{Km}^{2}$ and is located between $33^{\circ} 47^{\prime} \mathrm{E}$ and $35^{\circ} 47^{\prime} \mathrm{E}$ longitudes and $0^{\circ} 38^{\prime} \mathrm{S}$ and $1^{\circ} 52$ ' $\mathrm{S}$ latitudes. The upper $65 \%$ of the area is in Kenya, while the remaining lower portion is in Tanzania (Figure 3.1).

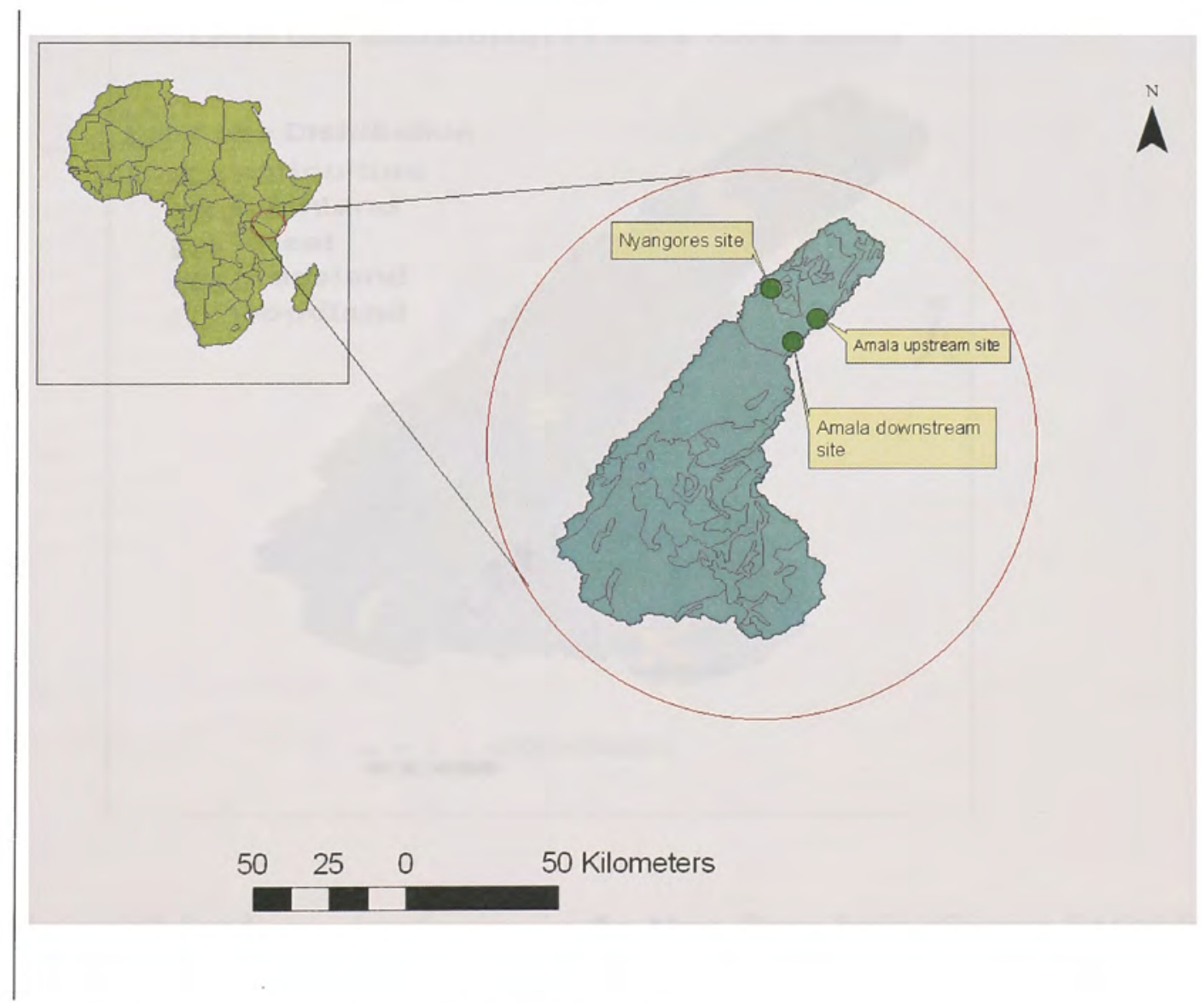

Figure 3.1 Mara River basin and the study area 


\subsubsection{Land use/Land covers}

The Mara River basin comprises of three major land uses. The upstream part of the basin covered by the Mau forest and small and large scale agricultural farm and in the downstream, the basin is covered by savanna grass. However, for this study a detailed classification was used and the basin classified as forest land, wood land, grass land, and bush lands as shown in Figure 3.2 below. The bush land in this classification indicates the lands that are covered by grass and bush plant species and woodland indicates a lowdensity forest forming open habitats with plenty of sunlight and limited shade.

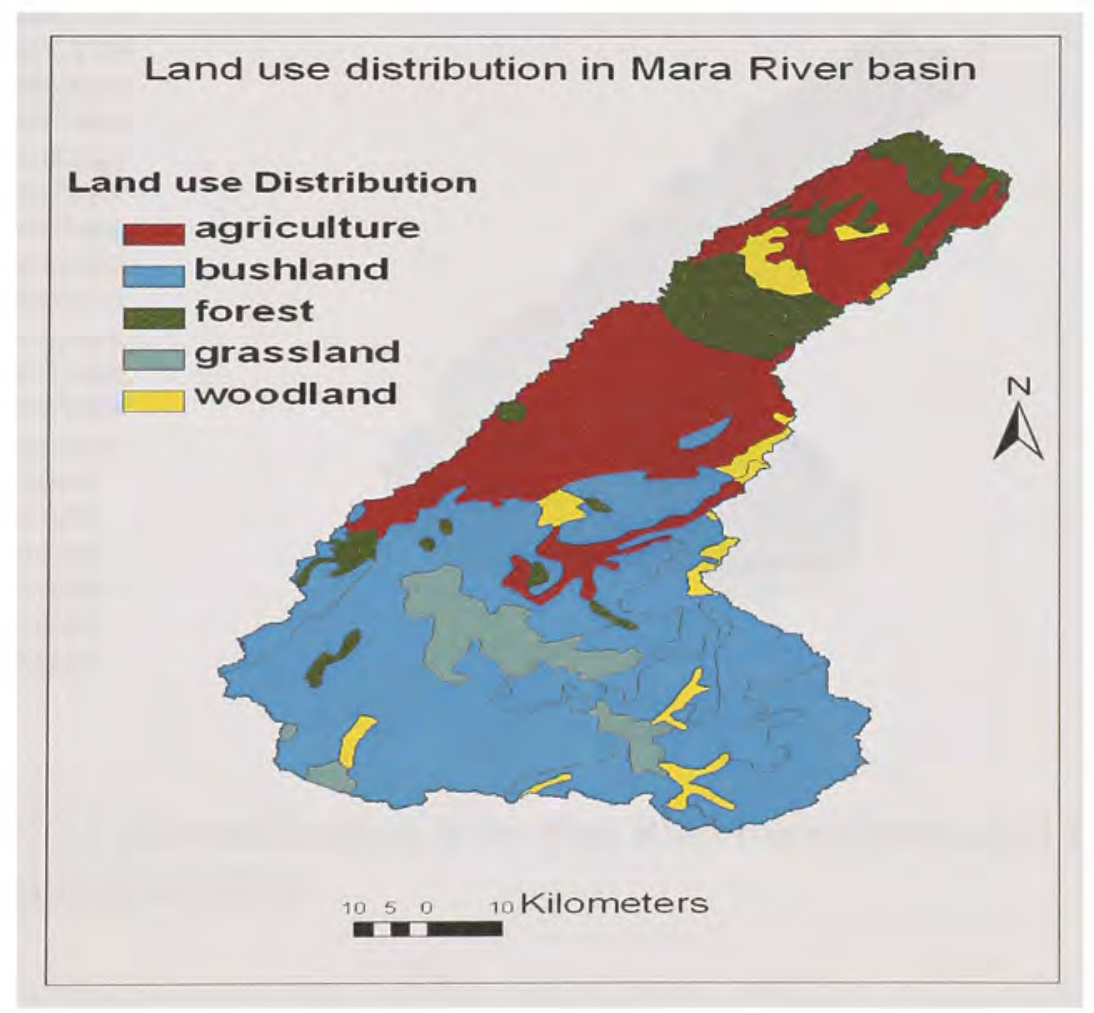

Figure 3.2 Land use classification in the Mara River basin (Source: FAO-Africover project (FAO, 2003)) 
3.1.3. Soil types in the Mara River basin

There are different types of soil in the Mara River basin that vary in texture from sand to clay. The different soil types in the Mara basin is shown in Figure 3.3, as per the Soil Terrain Database of East Africa (SOTER) classification and Table 3.1 shown the major soil types with particle size percentage.

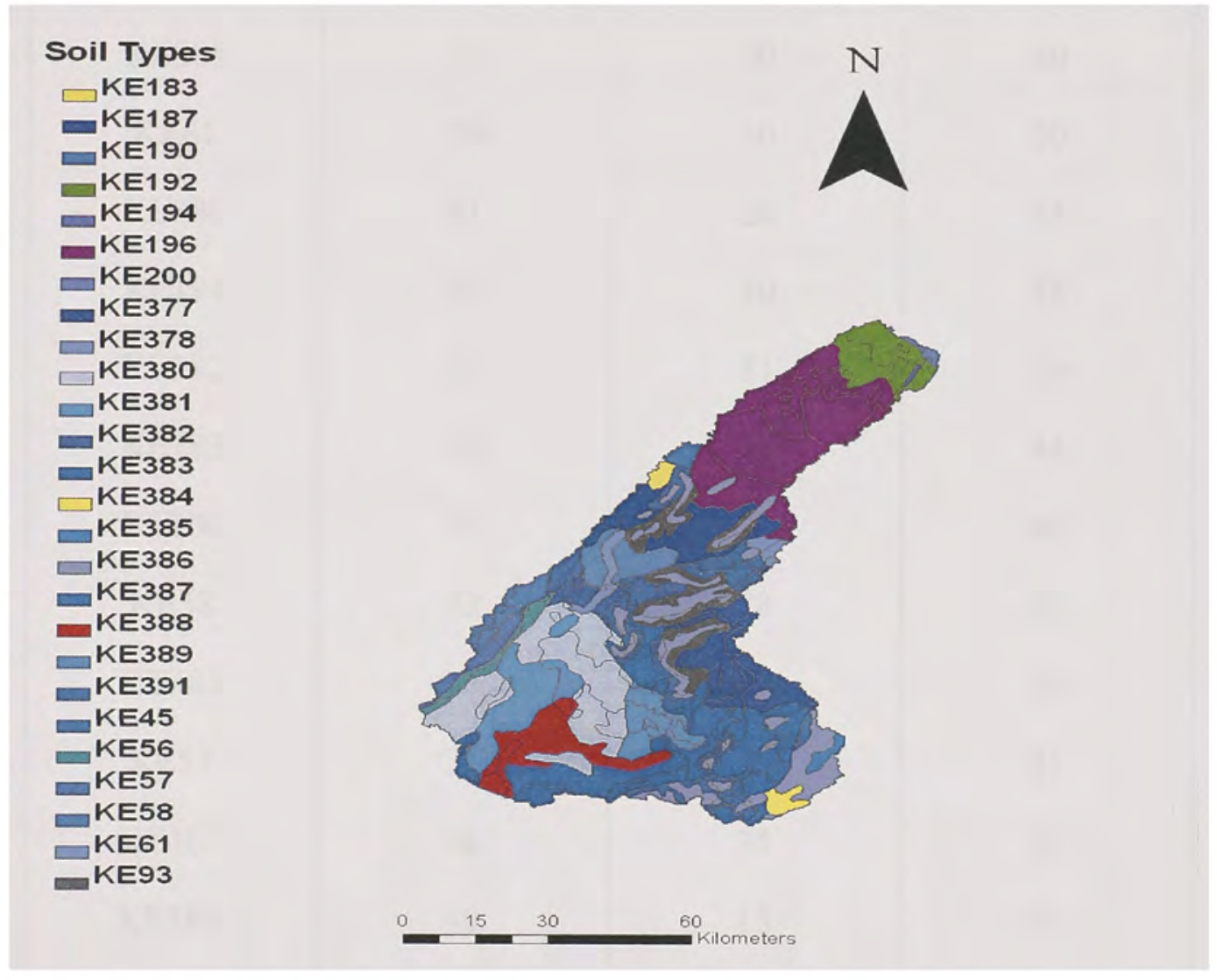

Figure 3.3 soil classifications in the Mara River basin (Source: Soil Terrain Database of East Africa (SOTER)) 
Table 3.1 Major Soils in the Mara River basin and their particle size distribution

\begin{tabular}{|c|c|c|c|}
\hline Soil type code & clay $\%$ & silt $\%$ & sand $\%$ \\
\hline $\mathrm{KE} 45$ & 9 & 67 & 24 \\
\hline KE190 & 10 & 28 & 62 \\
\hline KE378 & 15 & 70 & 15 \\
\hline KE192 & 20 & 48 & 32 \\
\hline KE388 & 20 & 20 & 60 \\
\hline KE61 & 20 & 30 & 50 \\
\hline KE380 & 21 & 26 & 53 \\
\hline KE194 & 22 & 50 & 28 \\
\hline KE382 & 25 & 51 & 24 \\
\hline KE183 & 30 & 26 & 44 \\
\hline KE200 & 31 & 29 & 40 \\
\hline KE58 & 32 & 28 & 40 \\
\hline KE383 & 33 & 37 & 30 \\
\hline KE57 & 35 & 20 & 45 \\
\hline KE187 & 38 & 35 & 27 \\
\hline KE385 & 40 & 15 & 45 \\
\hline KE386 & 41 & 29 & 30 \\
\hline KE196 & 42 & 42 & 16 \\
\hline KE377 & 58 & 26 & 16 \\
\hline KE389 & 58 & 26 & 16 \\
\hline KE56 & 60 & 19 & 21 \\
\hline
\end{tabular}




\subsubsection{Rainfall distribution in the Mara River basin}

There is a spatial variability of rainfall within the Mara River basin. The upstream of the basin gets high amounts of annual rainfall and the downstream receives lower rainfall. The mean annual rainfall in the Mara River basin varies from 900 to $1300 \mathrm{~mm}$ and there is temporal variation in rainfall. The graph below indicates the mean monthly rainfall variation as recorded at the Bomet water supply meteorological station. This monthly variation in rainfall indicates the variation in the upstream side/the Kenya's side of the Mara River basin. As shown in the graph below, the highest rainfall occurs from March to April and from October to December and the lowest rainfall amount occurs from June to September.

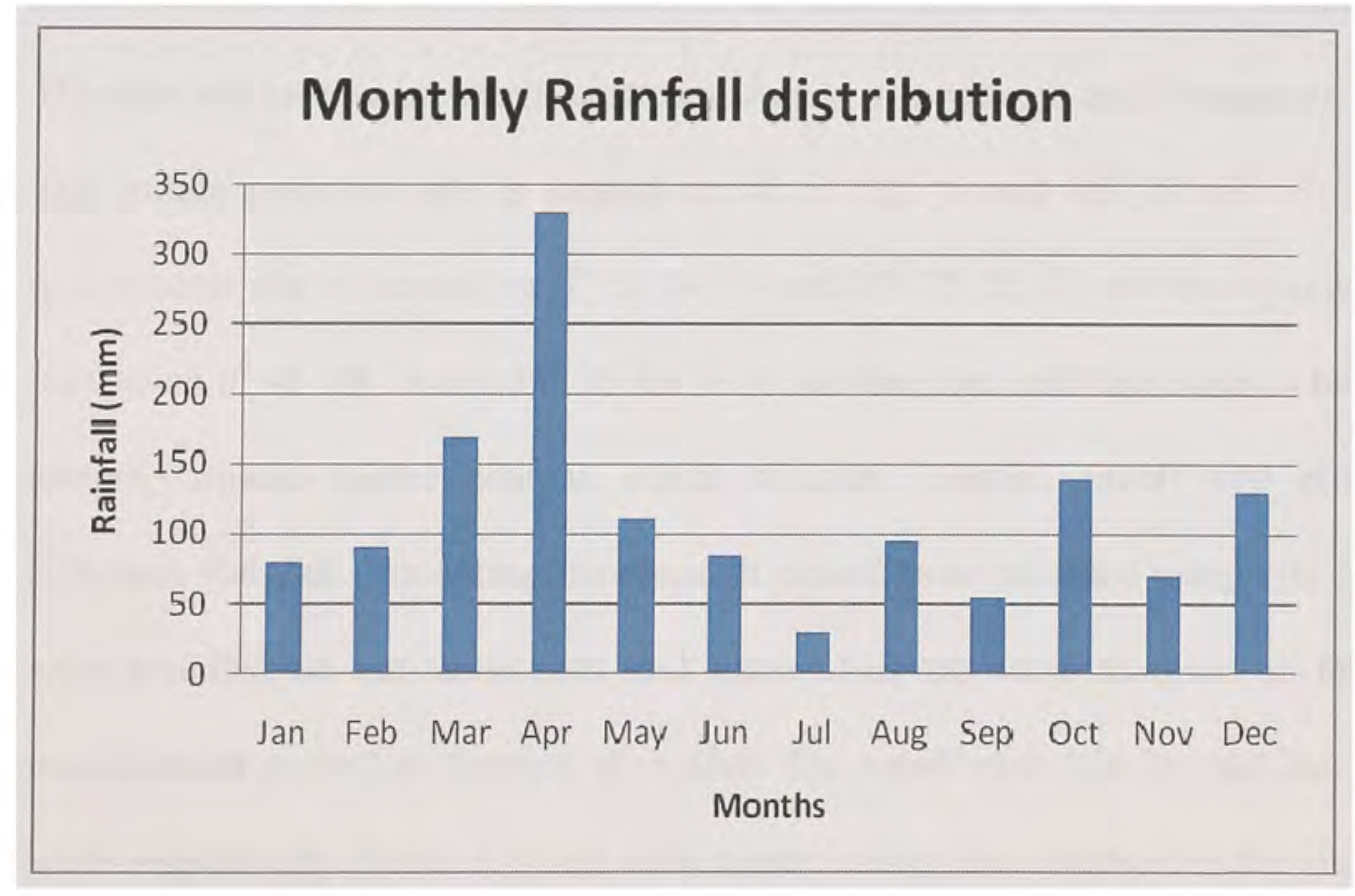

Figure 3.4 Average monthly rainfalls at Bomet water supply metrological station (19702004). 


\subsection{Experimental Procedures}

Soil erosion and surface runoff processes can be viewed at various scale levels (Wickenkamp, et al. 2000). Depending upon the research objectives and the nature and types of models intended to be used, such processes can be viewed at small plots and test plots scale, at individual field or slopes, and at catchments area of small streams or at entire area of rivers. In this study, the hydrological and erosion processes on the Mara River basin were investigated and modeled at two scales: plot and watershed scales.

\subsubsection{Procedures at field plot scale}

Runoff/erosion plots were established in the uphill areas at three sites within the basin. The sites are located in Amala upstream, Amala downstream and Nyangores watershed. The Amala upstream site is located on $0^{\circ} 53^{\prime} 32^{\prime \prime} \mathrm{S}$ and $35^{\circ} 27^{\prime} 63^{\prime \prime} \mathrm{E}$; the Amala downstream site is located on $0^{0} 56^{\prime} 34^{\prime \prime} \mathrm{S}$ and $35^{\circ} 25^{\prime} 25^{\prime \prime} \mathrm{E}$, and the Nyangores site is located on $0^{\circ} 45^{\prime} 09^{\prime \prime} \mathrm{S}$ and $35^{\circ} 20^{\prime} 63^{\prime \prime} \mathrm{E}$. In all the sites, soil data such as bulk density, texture, organic matter content, initial moisture content, runoff and erosion were collected. Rainfall data during the research period were collected using rain gauges that were installed on the three sites and three observers were assigned to take rainfall measurement as well as duration of rainfall. The runoff plots had $3 \mathrm{~m}$ and $2 \mathrm{~m}$, length and width respectively (Table 3.2) and were constructed in the direction of the main slope of the field. The plots were constructed in three cover types: grass cover, bare land cover that had been established by removing the grasses from the grassland with little disturbance on the soils and corn cover (Fig 3.5and 3.6). Table 3.2 indicates, soil particle 
size distribution of the three soils, which were determined by pipette methods following the procedures of the U.S. Soil Conservation Service (1967) and sedimentation time recommended by Tanner and Jackson (1947).

To avoid interaction, the plots were bounded in the upstream side and in the two sides along the slope (Figure 3.5). In the downstream side, the runoff collector troughs were constructed and the pipes, which convey runoff, were installed from the collector trough to the sediment collecting tank (Figure 3.5). The runoff sediment tanks were covered by a plate in order to avoid direct entrance of rainfall. Prior to taking samples from the collectors the sediment were uniformly mixed and data were taken using sampler. The suspended sediments were separated from runoff using sediment filter and the sediments were oven-dried with pre-weighted petri dish using oven for 24 hours (Figure 3.6). The oven-dried samples were multiplied by the total volume of runoff to get the total sediment yield from the sample area and the data became ready for further analysis. The collected runoff, sediment yield, rainfall and other soil parameters were analyzed and the data were also used to evaluate the WEPP and Erosion 3D/2D models. 


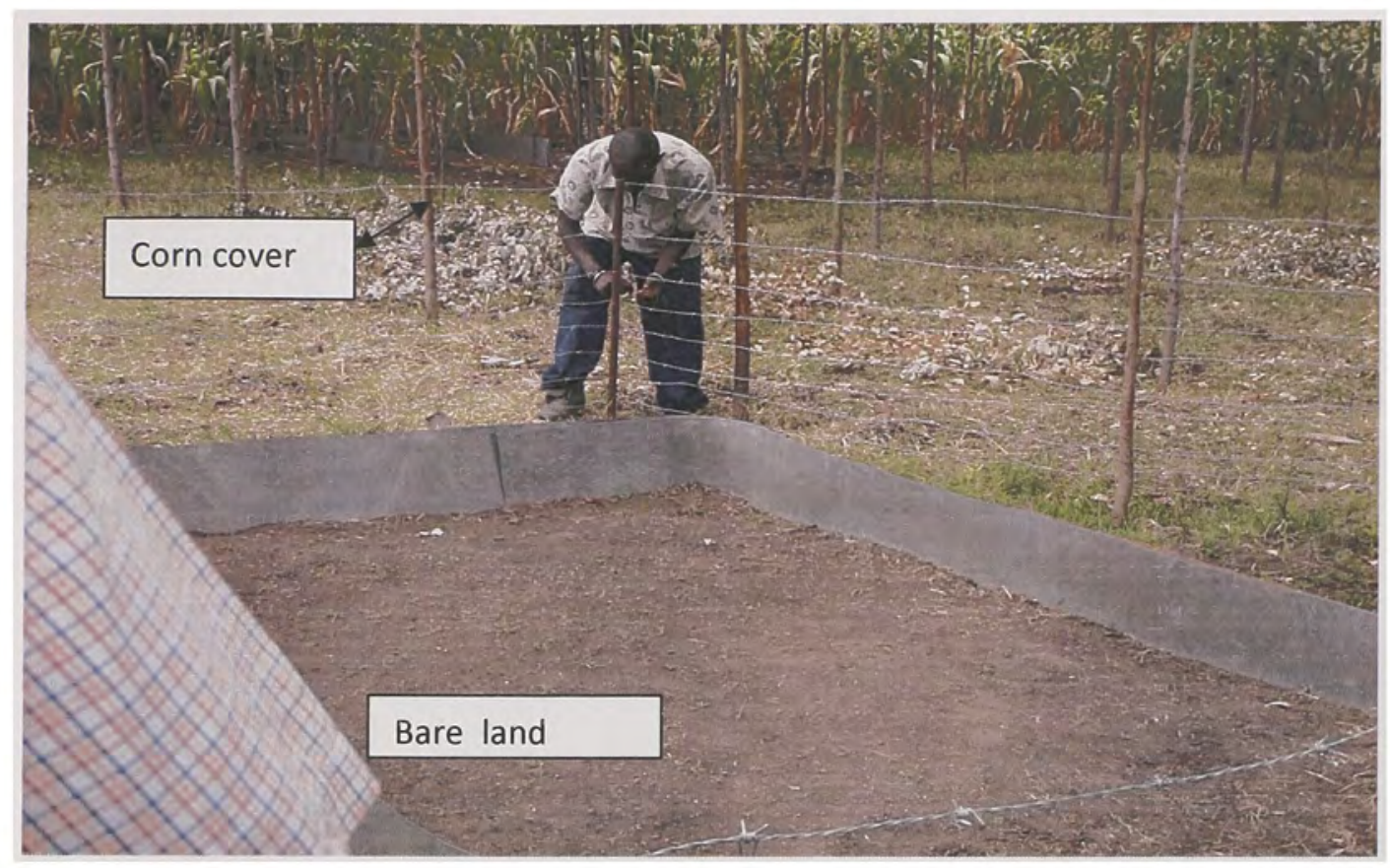

Figure 3.5 Runoff plots on bare land and corn covered in the Amala upstream

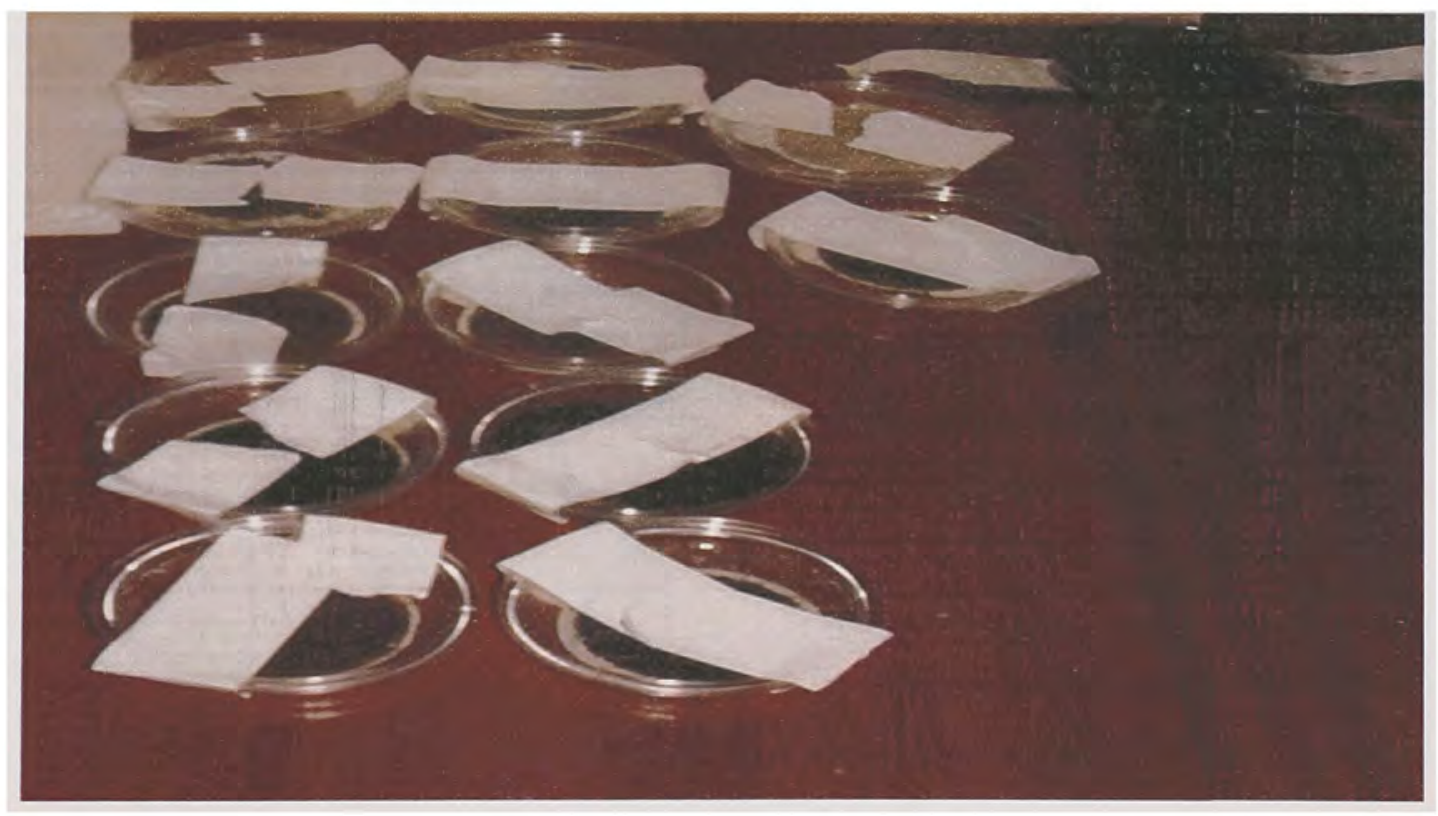

Figure 3.6 Sediment sampling method using petri dish to determine the sediment load for every rainfall event 


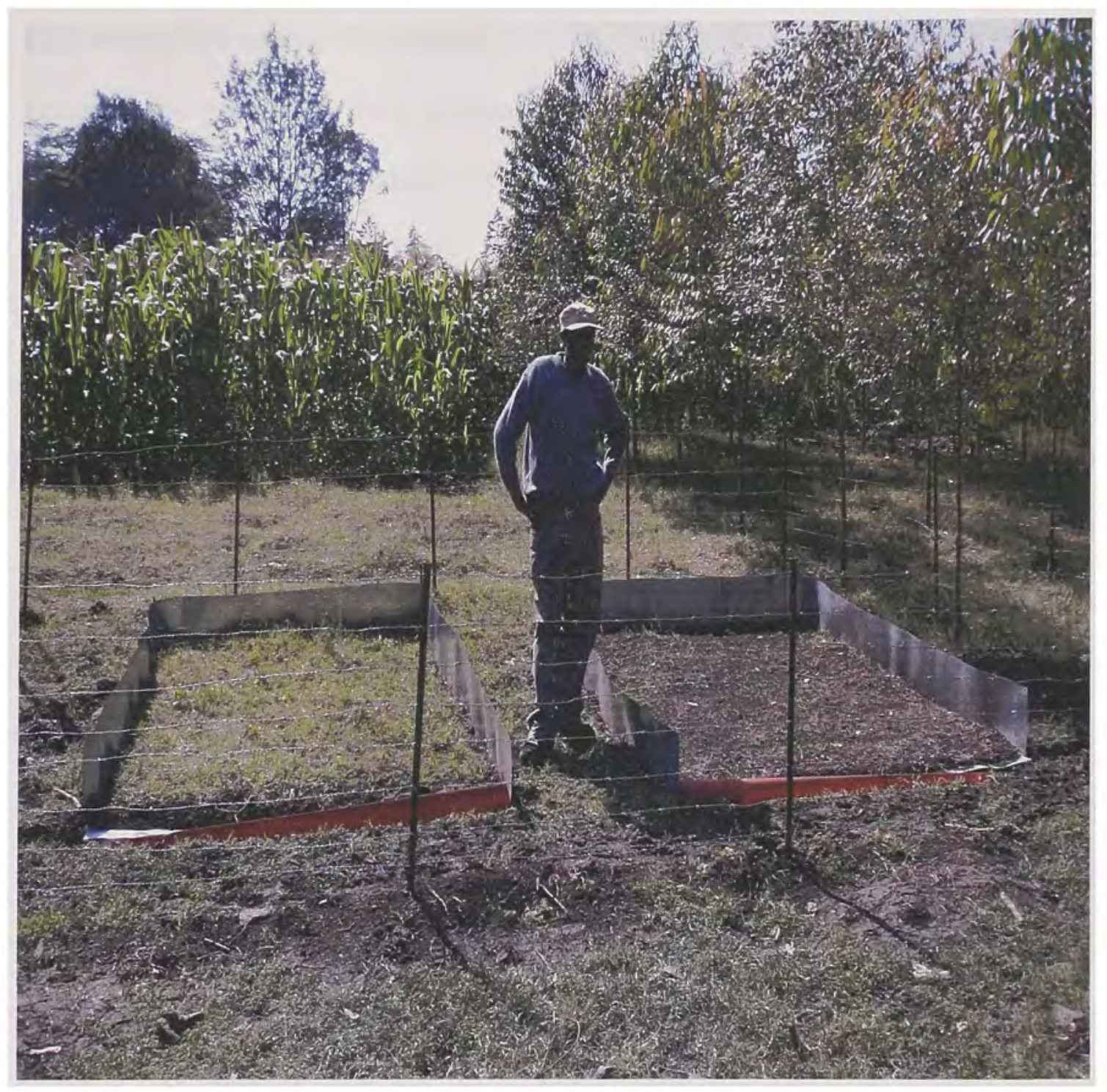

Figure 3.7 Runoff plots with grass cover and bare land in the Amala downstream 


\subsubsection{Model Performance Evaluation}

Theoretically, parameters for a physical based erosion and hydrological model are all measurable in the field (Madsen, 2003). In this study, the Water Erosion Prediction Project (WEPP) and Erosion 3D/2D models were evaluated using data that were collected at field plot scales from three sites and three land uses in the Mara River basin. The necessary input parameters were collected from these sites and other input parameters such as, erodibility of soils, erosion 3D soil resistances, infiltration factor in Erosion $3 \mathrm{D} / 2 \mathrm{D}$, and others were generated by using the parameter catalogue (see Appendix Tables 1 and 2). In the WEPP model, the interrill erodibility and rill erodibility values were calculated by the model, however, in Erosion 3D the erodibility parameter for all of the soils was estimated on the basis of the parameter catalogue. To run the WEPP model, new soil file and management files were created for each sites and land uses. Especially, the management file for ox-plow was not available in the WEPP database and as a result a new database was created using depth of plow and roughness data as described by Zeleke (2001 (Figures 3.8, 3.9 and 3.10). In the figures below, the crop calendar, type of operation and depth of plow data are included. Moreover, data such as ridge interval, ridge height, percentage residue buried on interrill areas were included.

In this study, both models were evaluated at the event basis and because of the limitation of the automatic rain gauges the rainfall intensities were assumed uniform/steady during every rainfall events. For both of the models, some of the input parameters were developed using the parameter catalog of the models. Additional information on the initial conditions of the plots is described in Table 3.2. The application of the (un- 
calibrated) models to simulate rainfall events in the nine plots, established in three sites were carried out and the models simulation performance were evaluated using correlation coefficients between the simulated and observed.

Table 3.2 Initial conditions of the Amala upstream, Amala downstream and Nyangores plots

\begin{tabular}{|c|c|c|c|c|c|c|c|c|c|c|}
\hline & & \multicolumn{3}{|c|}{ Amala upstream } & \multicolumn{3}{|c|}{ Amala downstream } & \multicolumn{3}{|c|}{ Nyangores } \\
\hline & unit & Grass & bare & corn & grass & bare & corn & grass & bare & $\mathrm{C}^{*}$ \\
\hline $\begin{array}{l}\text { Mean } \\
\text { slope }\end{array}$ & $\%$ & 10 & 10 & 10 & 7 & 7 & 7 & 15 & 15 & 15 \\
\hline \multirow[t]{3}{*}{ Texture } & Clay $\%$ & 55.8 & 55.8 & 55.8 & 49.8 & 49.8 & 49.8 & 64.8 & 64.8 & 64.8 \\
\hline & Sand $\%$ & 19.2 & 19.2 & 19.2 & 16.2 & 16.2 & 16.2 & 13.2 & 13.2 & 13.2 \\
\hline & Silt \% & 25 & 25 & 25 & 34 & 34 & 34 & 22 & 22 & 22 \\
\hline $\begin{array}{l}\text {-Organic } \\
\text { matter }\end{array}$ & gm & 2.15 & 2.15 & 2.9 & 3.16 & 3.16 & 3.24 & 2.87 & 2.87 & 2.92 \\
\hline $\begin{array}{l}\text { Bulk } \\
\text { density }\end{array}$ & $\mathrm{gm} / \mathrm{cm}^{3}$ & 1.5 & 1.5 & 1.4 & 1.4 & 1.4 & 1.35 & 1.4 & 1.4 & 1.35 \\
\hline $\begin{array}{l}\text { Surface } \\
\text { cover }\end{array}$ & $\%$ & 80 & 0 & 70 & 85 & 0 & 70 & 80 & 0 & 70 \\
\hline $\begin{array}{l}\text { Surface } \\
\text { condition }\end{array}$ & & 亭 & : & 草 & 亭 & : & 䓛 & 荅 & పี & * \\
\hline $\begin{array}{l}\text { Initial } \\
\text { moisture }\end{array}$ & $\%$ & 20 & 20 & 20 & 15 & 15 & 15 & 20 & 20 & 20 \\
\hline
\end{tabular}

$\mathrm{P}^{*}$ : plowed; $\mathrm{C}^{*}$ : cultivated

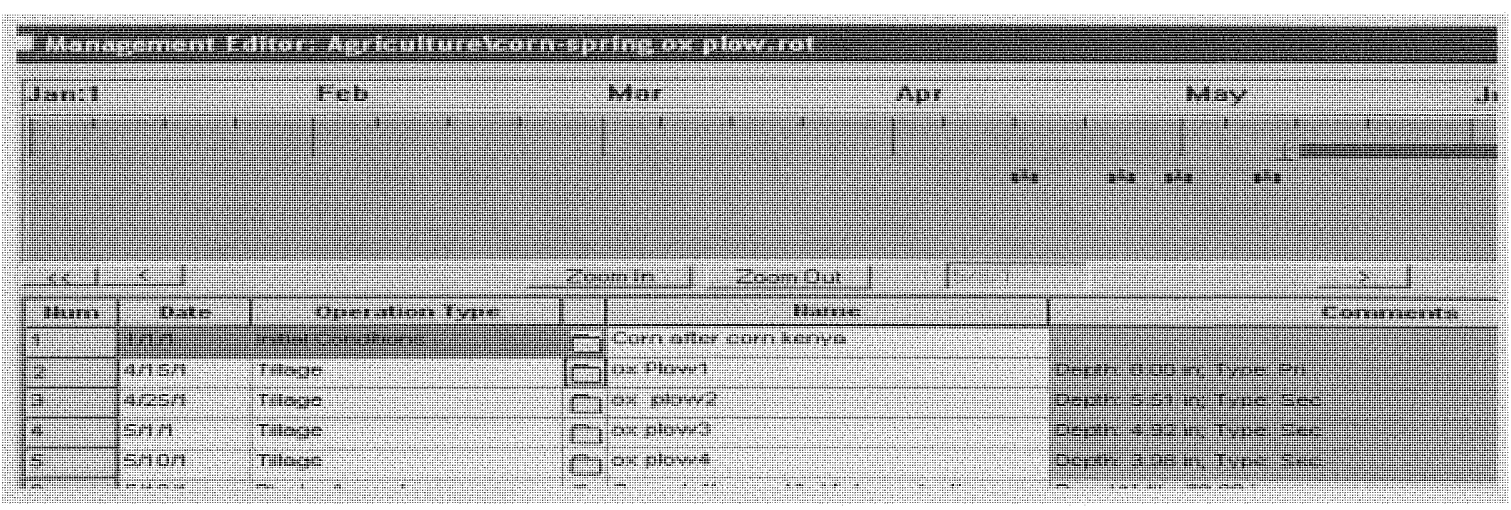

Figure 3.8 Management file preparation for WEPP model using Ox plow 


\section{Operations Database}

Operation

Description:

ox Plow1

Data Source:

"Oxplow"

Comment:

Buries 10 percent of surface residues

Primary as well as secondary tillage using $\mathrm{Ox}$ plow

\begin{tabular}{|l|l|l|l|l|}
\hline Num & \multicolumn{1}{|c|}{ Parameter } & \multicolumn{1}{c|}{ Value } & \multicolumn{1}{c|}{ Units } \\
\hline 1 & Percent residue buried on interrill areas for fragile crops & 10 & $\%$ \\
\hline 2 & Percent residue buried on interrill areas for non-fragile cr & 10 \\
\hline 3 & Number of rows of tillage implement & $\%$ \\
\hline 4 & Implement Code & 0 & \\
\hline 5 & Cultivator Position & Other & \\
\hline 6 & Ridge height value after tillage & 5.118 & inches \\
\hline 7 & Ridge interval & 14.17 & inches \\
\hline 8 & Percent residue buried on rill areas for fraqile crops & 10 & $\%$ \\
\hline
\end{tabular}

Tillage Depth(in): $\longdiv { 8 } \quad$ Tillage Type: Primary

English Units

Save As

Save

Cancel

Help

\section{Figure 3.9 Primary Tillage 'First Tillage'}

\section{Operations Database}

Operation

Description:

Data Source:

Comment:

\section{ox plow4}

primary as well as secondary tillage using $0 \times$

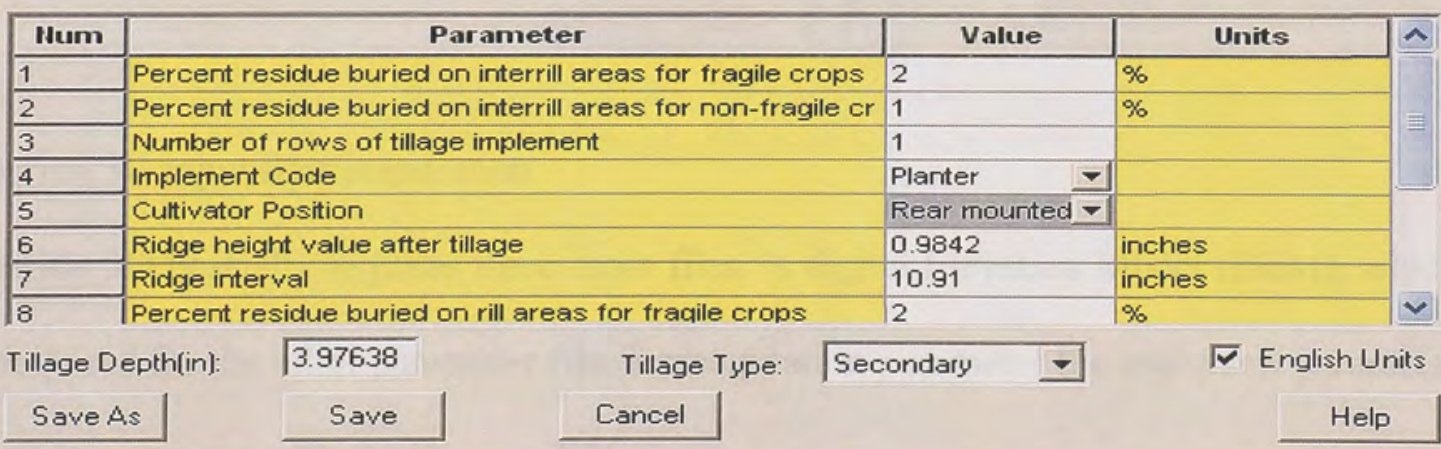


In the simulation, moisture content at different values was used. For the first rainfall events; initial moisture content as described in the above table were used, however, for the rest of the rainfall events various moisture content depend on the interval between two consecutive rainfall events were used. If the variation between two consecutive rainfalls is 1 to 3 days, the moisture content at field capacity was used. If the rainfall that occurs in the same day, for the second rainfall event moisture content is considered from $70-80 \%$ depends on the first rainfall and soil type (Appendix Table 2).

\subsubsection{Application of Erosion 3D model at watershed level}

Considering the data limitation in the study area and the little input parameter requirement of Erosion 3D/2D relative to WEPP, the model was selected to be applied at watershed scale in the study area. Moreover, the model is a process based model unlike USLE, RUSLE and other; as a result its applicability is not as such limited in other areas as empirical models. Because of these reasons, the EROSION 3D model was applied at the watershed scale to identify potential sediment source areas in the Mara River basin.

Erosion 3D input files preparation

Erosion 3D basically requires three input files. A digital Elevation Model (DEM), which is required for the relief parameter file, a precipitation parameter file and a soil parameter file (all generated with the Erosion 3D). 
Rainfall parameter file

Erosion 3D simulates soil erosion and deposition for individual time steps of a rainfall event. In the study area, three rain gauge stations (the Bomet water supply meteorological station, Tenweek meteorological station, and the Hail Research Station) data were used to run the model.

Land use and soils (soil parameter file)

Land use and soil parameters for each raster cell were assigned by an overlay of a soil and a land use map. This assignment was completed in ArcGIS 9.1. This overlay leads to delineated areas which are defined by a land use and a soil type. This information was created in ArcGIS 9.1 tables and was exported for Erosion 3D applications. Since soil and land use conditions are temporally variable, they must be modeled dynamically according to the plant development, main cultivation periods and land management techniques. Soil parameters such as bulk density (for cultivated land) and soil moisture, and land use parameter such as land cover (specially for cultivated land) and roughness, vary within different seasons and growth stages of crops and as a result for long-term simulation these parameters were averaged following the model parameter catalogue (Schmidt, 1992).

\section{Surface Roughness}

Surface roughness was estimated with the help of the parameter catalogue. Its calculation is derived from roughness values ascertained by the Manning Formula. Since roughness 
increases with the development of the plant cover, it also needs to be averaged for the entire growth period.

Soil moisture

Initial soil moisture data as developed in the Soil Terrain Database of East Africa (SOTER) was used for this study, however, since the model is sensitive for moisture content and was run for long time (annual) basis; the soil moisture averaged for the entire plant growth period was used for the parameter catalogue estimation method as described above.

Erodibility and Infiltration correction factor

Erodibility values, like roughness values, were estimated with the help of the parameter catalogue. Erodibility depends on various impact factors and is not easily measured in field studies. Interrill soil erodibility is not a fundamental property of the soil but is defined by the specific equation and the period of time that rainfall occurs (Bradford and Foster, 1996). Even here values on cultivated areas changes between sowing time and maximum crop stages. As a result average values of erodibility were used.

According to Schmidt et al. (1999), infiltration ratios depend on factors such as secondary pores and sealing of soil surfaces during rainfall events. Infiltration ratio/skin factors for the different soils in the study area were used depending on the soil types/silt contents of the soil, and land using the parameter catalogue. 
Chapter 4

\subsection{Results and Discussions}

In this section, the research results are discussed in three parts. In the first sub-section, the results on the effects of land use change on runoff and sediment yield is discussed on the basis of data collected from runoff plots at three sites. The WEPP (Water Erosion Prediction Project model) and the Erosion 3D models were evaluated using the runoff plot data and the results are discussed in the second sub-sections and in the final subsections, the results of Erosion 3D model application at watershed scale is discussed.

\subsection{Land cover change, runoff rate and sediment yield}

After scrutinizing the data collected from runoff plots that were installed at three sites (Amala upstream, Amala downstream, and Nyangoroes) with three different land uses/covers (grass, bare land, and cultivated land covered with corn) the results are discussed below.

\subsubsection{Sediment variation in the Amala upstream}

During the research period, six rainfall events were observed in the Amala upstream site and the total amount of sediment observed in the three land covers varied significantly. The highest total sediment yield per unit area $\left(100 \mathrm{~g} / \mathrm{m}^{2}\right)$ was observed on bare land and the lowest sediment yield $\left(36.1 \mathrm{~g} / \mathrm{m}^{2}\right)$ was observed on grass cover. Total sediment yield per unit area from cultivated land with corn cover at maturity level was $88.1 \mathrm{~g} / \mathrm{m}^{2}$. 
Results show that changing land use from grassland to cultivated land may increase soil loss/sediment yield with a minimum by $144.1 \%$. However, it is clear that the result would be more than $144.1 \%$ because in this study the data were collected in the corn field after it was mature and the rate at different growth stage of corn would increase sediment yield. Similarly, change in land use from grassland to bare land increased total sediment yield by $177.37 \%$. In this research, the bare land was simulated by removing grass and as a result, the sediment yield from corn cover was almost similar to soil loss in bare land because in the corn cover plots, even though the soil was covered by corn; cultivation pulverized the soil, and may increase erodibility of the soil. According to El-Swaify (1982), cultivation increases soil loss by pulverizing soil.

The average sediment yield per unit area observed during the data collection period was $16.68 \mathrm{~g} / \mathrm{m}^{2}, 14.68 \mathrm{~g} / \mathrm{m}^{2}$ and $6.01 \mathrm{~g} / \mathrm{m}^{2}$ from bare land, corn, and grass cover respectively. As indicated in Figure 4.1, the sediment yield for each rainfall event per unit area from the runoff plot data were higher for corn cover and the lowest was observed on grass cover for all rainfall events except one. However, during one of the rainfall events, which was the highest rainfall event that was observed in this site during the research period, sediment yield was by far highest on bare land cover. It was about three times higher than the sediment yield that was observed on corn cover and about 5 times higher than the sediment yield observed on grass cover. As indicated in the runoff coefficient in Figure $4.3,98 \%$ of the rainfall amount on this event was lead to runoff, such increase in runoff with increase in detachment may increase the total sediment transported on bare 
land/cover. Moreover, the result also indicated that extreme events had highest contribution for the total sediment yield on the Amala upstream site. As depicted in Table $4.1,56.4 \%$ of the total sediment yield from bare land/cover, $30.5 \%$ from grass cover and $37.3 \%$ from corn cover during the study period were contributed by single rainfall event. Coppus and Imesson (2002) and Brookhagen (2010) obtained similar results on the effect of extreme events on erosion; according to the authors significant portion of annual erosion in the semi-arid area of southern Bolivia was contributed by single rainfall event and the majority of the rainstorms play only a minor role.

Table 4.1 Extreme event contributions to total sediment yield per unit area in the Amala upstream

\begin{tabular}{|l|l|l|l|}
\hline & Bare cover & Grass cover & Corn cover \\
\hline Total Sediment Yield $\left(\mathrm{g} / \mathrm{m}^{2}\right)$ & 100.1 & 36.1 & 88.1 \\
\hline Extreme event Sediment yield $\left(\mathrm{g} / \mathrm{m}^{2}\right)$ & 56.47 & 11.0 & 32.9 \\
\hline $\begin{array}{l}\text { Percentage contribution of extreme } \\
\text { event to total sediment yield }(\%)\end{array}$ & 56.4 & 30.5 & 37.3 \\
\hline
\end{tabular}




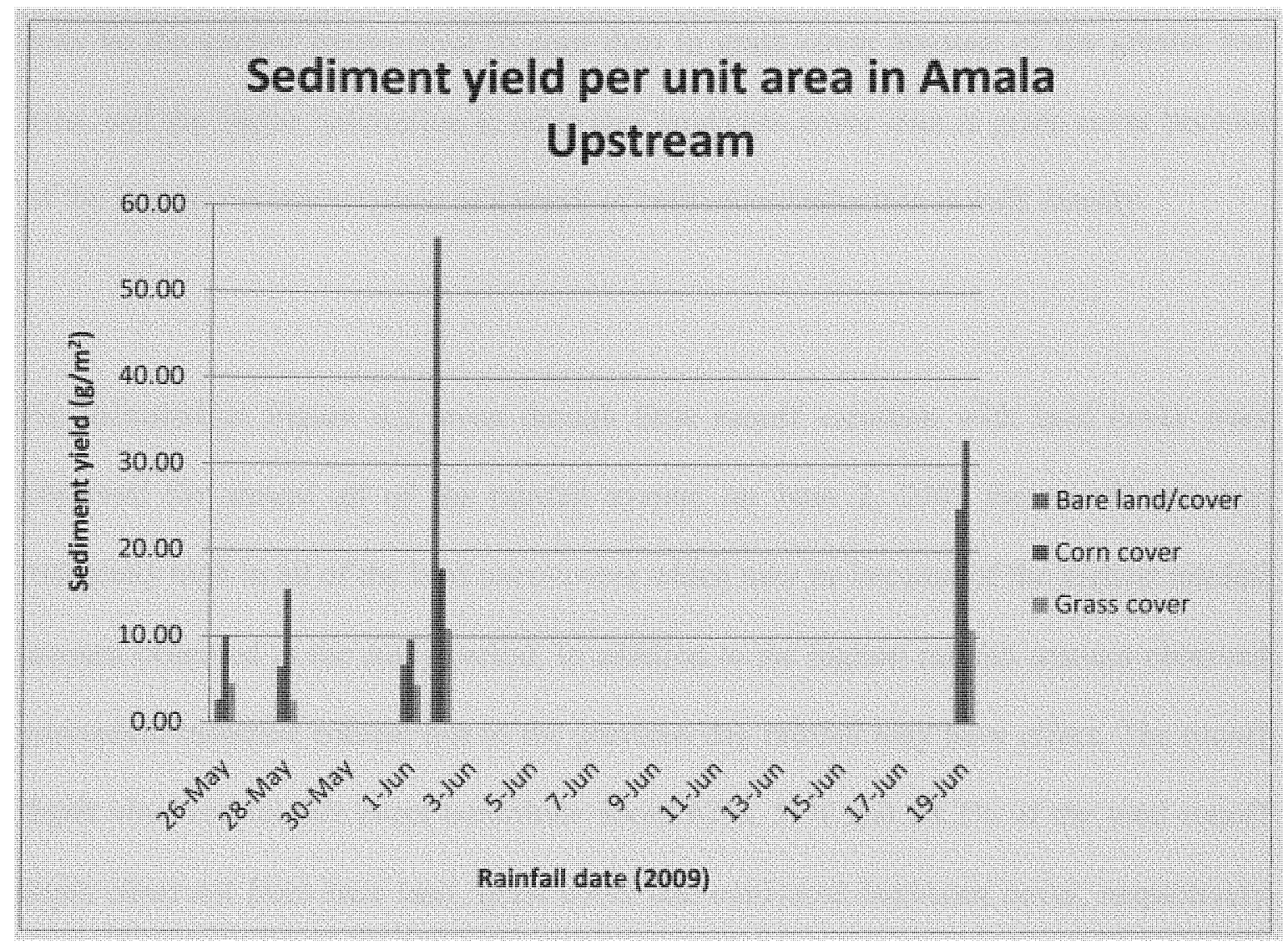

Figure 4.1 Sediment variations with land cover in the Amala upstream

\subsubsection{Runoff variation in Amala upstream}

The runoff depths observed during the research period at different rainfall event varied from $1.79 \mathrm{~mm}$ in grassland to $16.39 \mathrm{~mm}$ in bare land/cover. The highest total depth of runoff, $26.85 \mathrm{~mm}$ was observed on bare land/cover and $20.14 \mathrm{~mm}$ and $16.20 \mathrm{~mm}$ of total runoff depth during the research period was observed on grass cover and corn cover, respectively. It is expected that the total runoff depth observed in bare land/cover was higher because of low interception, high in velocity of runoff, and little time for water to infiltrate to the soil. The total runoff depth observed from cultivated land with corn cover at maturity was lower than the total depth observed from grass cover. The reason for this 
may be the greater interception in corn than in grass cover because of the greater leaf area, and the higher infiltration in cultivated land/corn cover than in grass cover because of the increase in macro-pores as a result of cultivation/reduction in bulk density.

As indicated in Figure 4.2, even though little runoff variation with land cover were observed for almost all of the rainfall events; on June 2, 2009 the runoff rate was extremely high in all of the land uses/covers which may be because of the highest rainfall amount observed in the study period. In addition to the highest rainfall amount observed antecedent moisture content due to the previous day rainfall may have effect. The runoff depth observed on this event contribute about $62 \%, 51 \%$ and $28.2 \%$ of the total runoff depth observed from bare land, grass cover and cultivated land/corn cover, respectively (Table 4.2).

Table 4.2 Extreme events contribution to the total runoff depth $(\mathrm{mm})$ in the Amala upstream.

\begin{tabular}{|l|l|l|l|}
\hline & Bare land & Grass cover & Corn cover \\
\hline Total runoff depth for the study period & 26.85 & 20.14 & 16.20 \\
\hline Runoff on June 2,2010 (mm) & & & \\
\hline Percentage contribution from the total (\%) & 61 & 51 & 4.57 \\
\hline
\end{tabular}




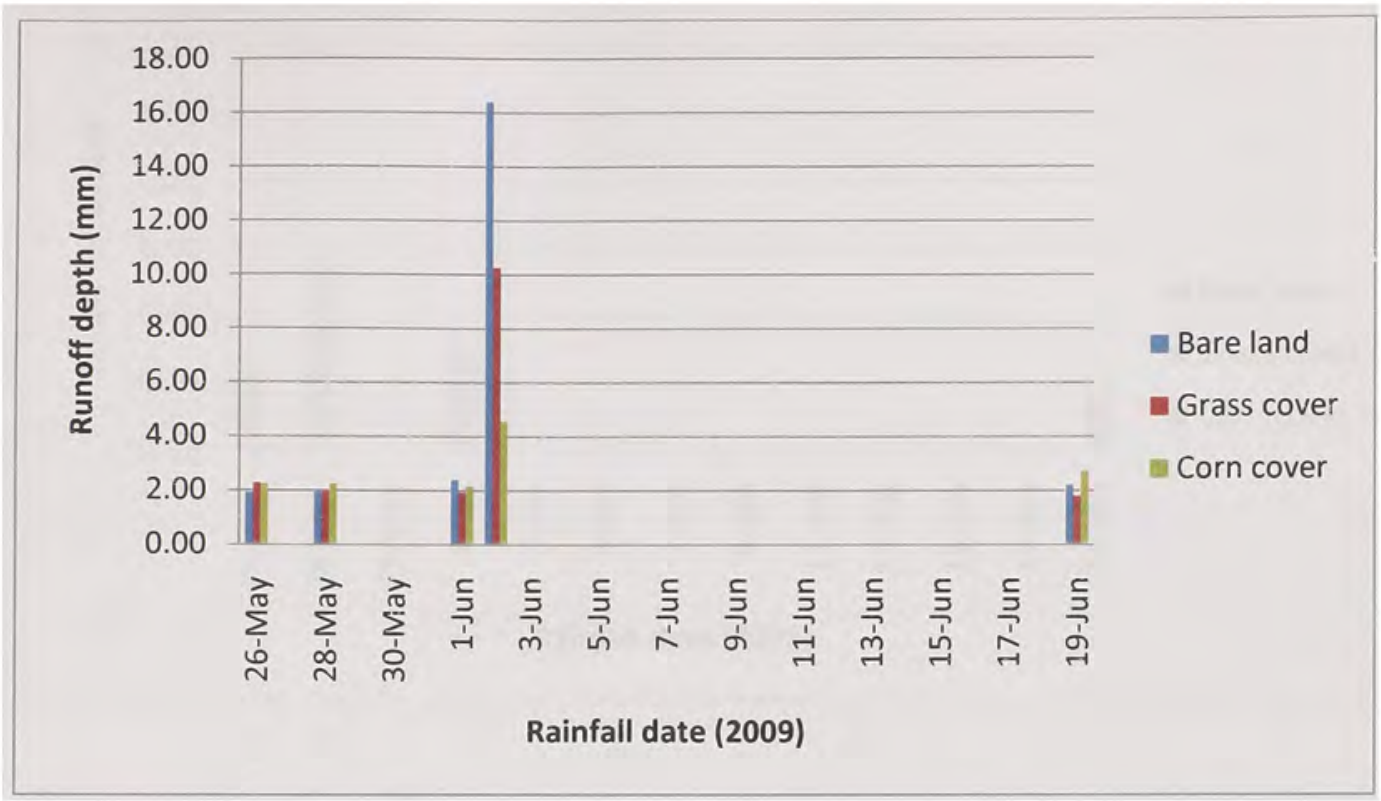

Figure 4.2 Runoff depth variations with land cover in Amala upstream

The highest average runoff coefficient with 0.47 , which is total runoff depth divided by total rainfall, was observed on bare land and the lowest runoff coefficient with 0.26 was observed on cultivated land covered with corn at maturity stage. For the entire study period, the maximum runoff coefficient, 0.98 , was observed on bare land. The lowest runoff coefficient, 0.14 , was observed on grass cover and similarly in this event lower runoff coefficient was observed within each land covers. 


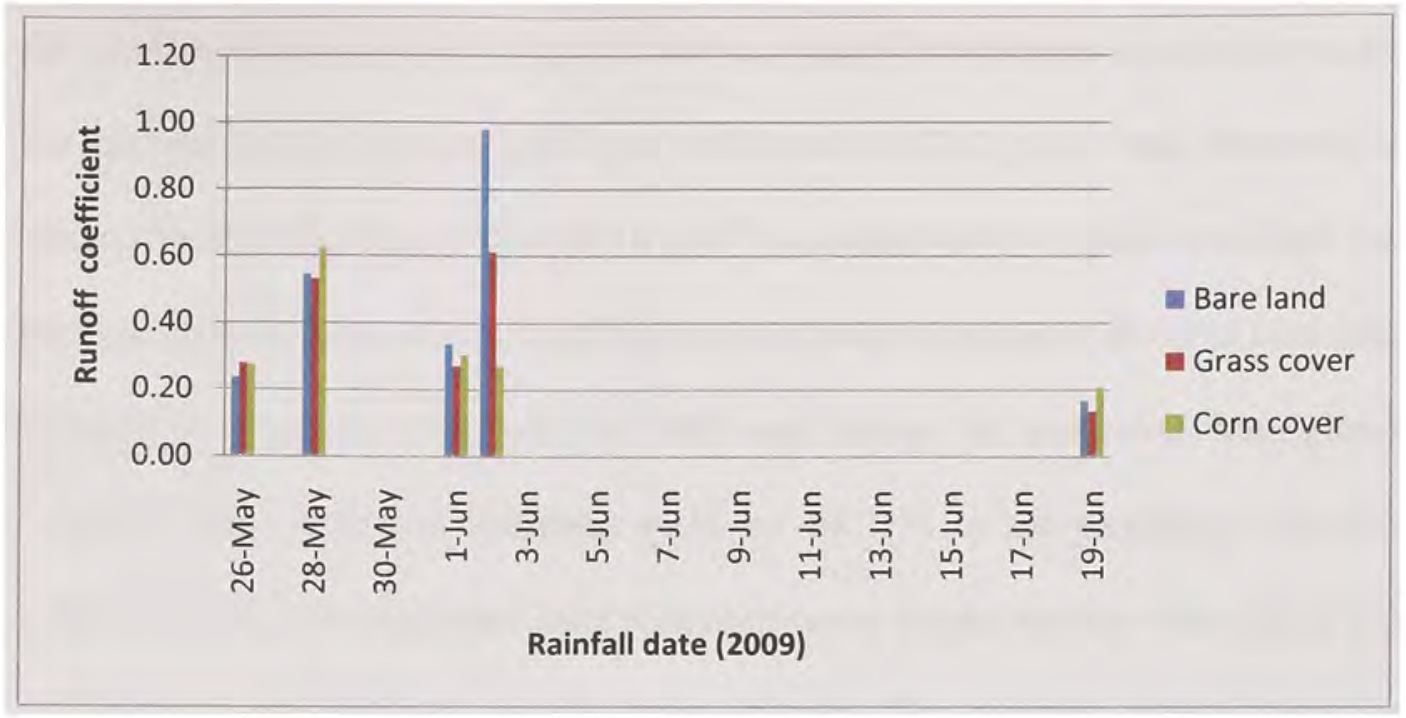

Figure 4.3 Runoff coefficient variations with land covers in the Amala upstream

\subsubsection{Sediment variation in Amala downstream}

During the study period, the lowest average total sediment yields per unit area in all types of land covers were observed in the Amala downstream site. In this site, the average total sediment yield per unit area of $3.53 \mathrm{~g} / \mathrm{m}^{2}, 2.23 \mathrm{~g} / \mathrm{m}^{2}$, and $8.07 \mathrm{~g} / \mathrm{m}^{2}$ were observed on bare land/cover, grass cover and cultivated land covered by corn, respectively. The reason for the lowest average total sediment yield observed on all of the land uses/covers may be a result of the low rainfall amount observed, the low slope steepness of the site, and the high organic matter content available in this site than the other two sites. The highest average total sediment yield in all of land uses/covers were observed in the Amala up stream site this may be due to the highest observed runoff and the lowest organic matter available in the sites relative to the other sites. 
For the rainfall events that were observed on Amala downstream during the study period the highest total sediment yield per unit area of $83.9 \mathrm{~g} / \mathrm{m}^{2}$ was observed on bare land/cover and $29.95 \mathrm{~g} / \mathrm{m}^{2}$ and $49.18 \mathrm{~g} / \mathrm{m}^{2}$ was observed for grass cover and cultivated land/corn cover, respectively. Land use/cover change from grass cover to bare land/cover increase soil loss/sediment yield by $180 \%$ and change in land cover from grassland to cultivated land increased sediment yield by $64.21 \%$ to the minimum. However, the sediment yield from cultivated land with corn cover would be more than this if data were collected for the different growth stage of corn. The extreme events contribution to sediment yield on different land covers were high. In the grass cover the extreme event contributes $56.5 \%$ of the total sediment load and such extreme events contributed about 29.5 and $37.1 \%$ of the total sediment yield observed in the study period for bare land/cover and cultivated land with corn cover, respectively (Table.4.3).

Table 4.3. Extreme events contribution to total sediment yield per unit area in the downstream Amala.

\begin{tabular}{|l|l|l|l|}
\hline & Bare Land & Corn cover & Grass cover \\
\hline Total sediment yield per unit area $\left(\mathrm{g} / \mathrm{m}^{2}\right)$ & 83.9 & 49.18 & 29.95 \\
\hline Total Sediment yield per unit area $\left(\mathrm{g} / \mathrm{m}^{2}\right)$ in & 24.73 & 15.64 & 16.93 \\
\hline extreme event $(\mathrm{g})$ & & & \\
\hline Sediment contribution of extreme events & 29.5 & 37.1 & 56.5 \\
\hline $\begin{array}{l}\text { Average Total sediment yield per unit area } \\
\left(\mathrm{g} / \mathrm{m}^{2}\right) \text { for seven rainfall events }\end{array}$ & 3.53 & 2.23 & 8.07 \\
\hline
\end{tabular}


For almost all rainfall events, highest rate of sediment yield was observed on bare land/cover and the lowest for almost all rainfall events were observed on grass cover. During the research period the highest rate of sediment yield with $24.73 \mathrm{~g}$ per square meter was observed on bare land/cover and the lowest with $0.05 \mathrm{gm}$ per square meter was observed on grass cover (Figure 4.4).

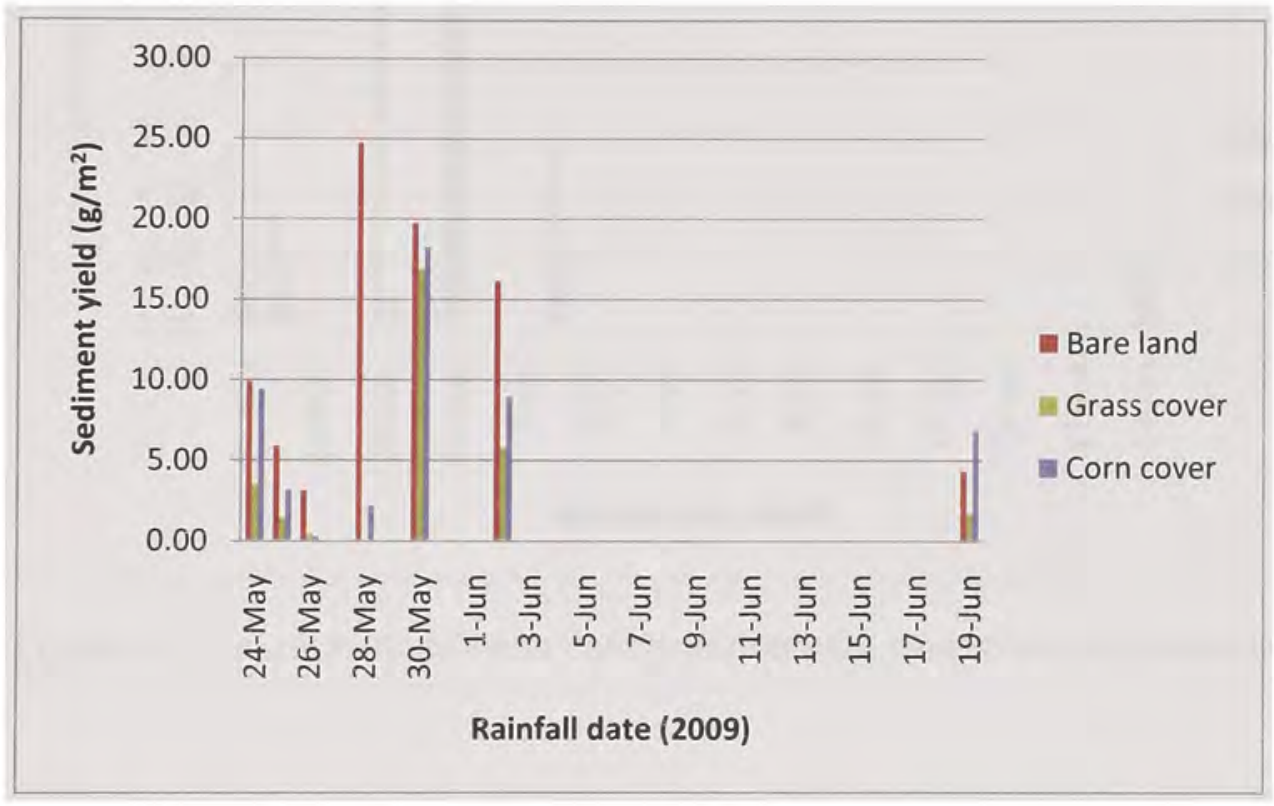

Figure 4.4 Sediment per unit area variations with land cover in Amala downstream watershed

Sediment concentration, which may be defined as the mass of sediment yield per total volume of runoff observed may roughly indicate the turbidity of the water, which, is closely related to total suspended solids (TSS). As indicated in Figure 4.5, sediment concentration varied with land cover. During the observation period, the highest sediment concentration of 12.5 gram per liter was observed on bare land/cover and the lowest sediment concentration of 0.02 gram per liter was observed on grass cover. The highest 
average sediment concentration, $5.21 \mathrm{~g} /$ liter, was observed on bare land and $3.6 \mathrm{~g}$ per liter and 2 gram per liter sediment concentration were observed on cultivated land/cover and grass cover, respectively.

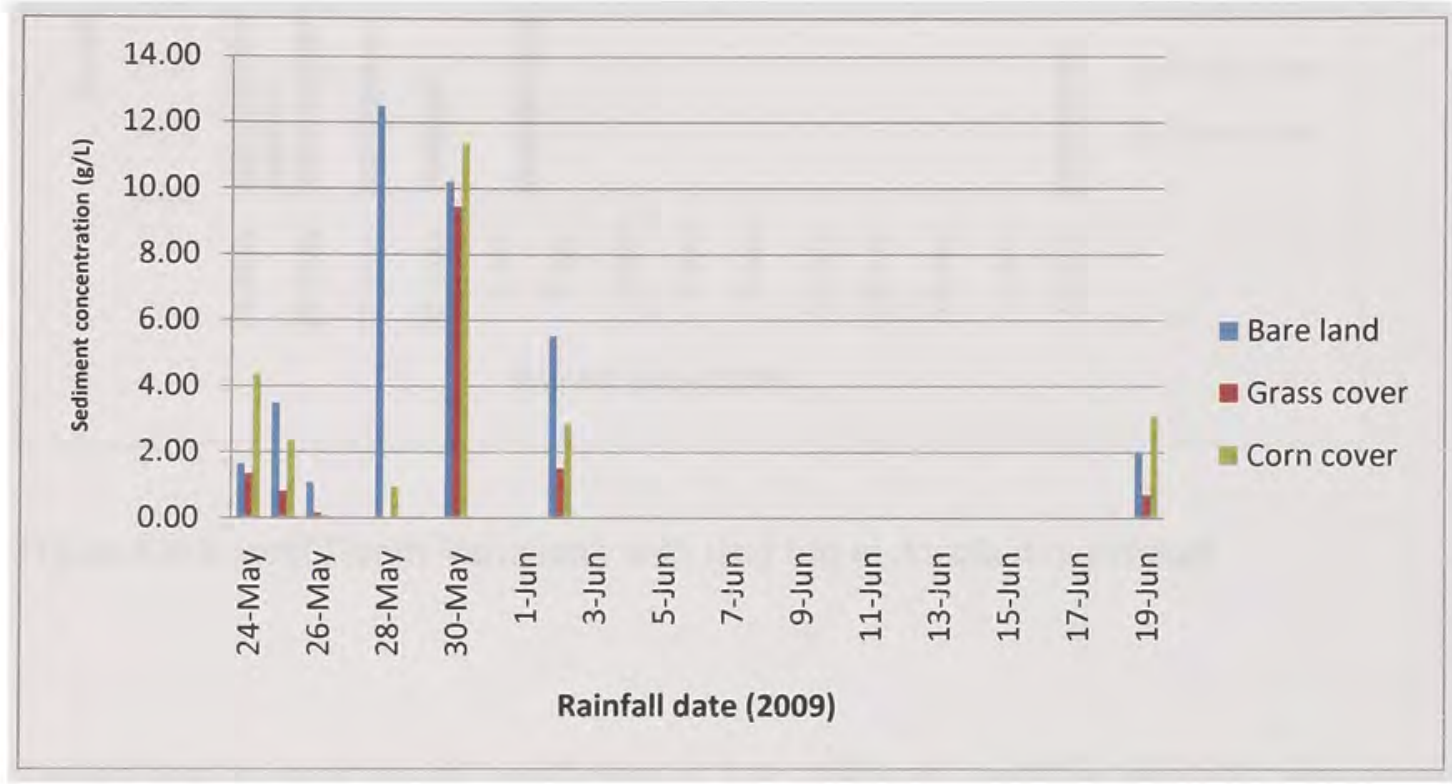

Figure 4.5 Variation in sediment concentration with land covers in Amala downstream

\subsubsection{Runoff variation in Amala downstream}

The runoff depths observed during the research period during different rainfall events varied from $1.60 \mathrm{~mm}$ in corn covered plot to $6.01 \mathrm{~mm}$ in bare land/cover. During the study period, the highest total depth of runoff observed from bare land, grass land and corn field were, 19.57, 17.80 and $15.35 \mathrm{~mm}$, respectively (Figure 4.6). As indicated above, the data were collected when the corn was mature stage and this indicated that the actual amount of runoff from cultivated land cover with corn might be greater than grass cover. The total runoff depth observed in bare land/cover was high as a result of low interception and high in velocity of runoff and little time for water to infiltrate to the soil. 


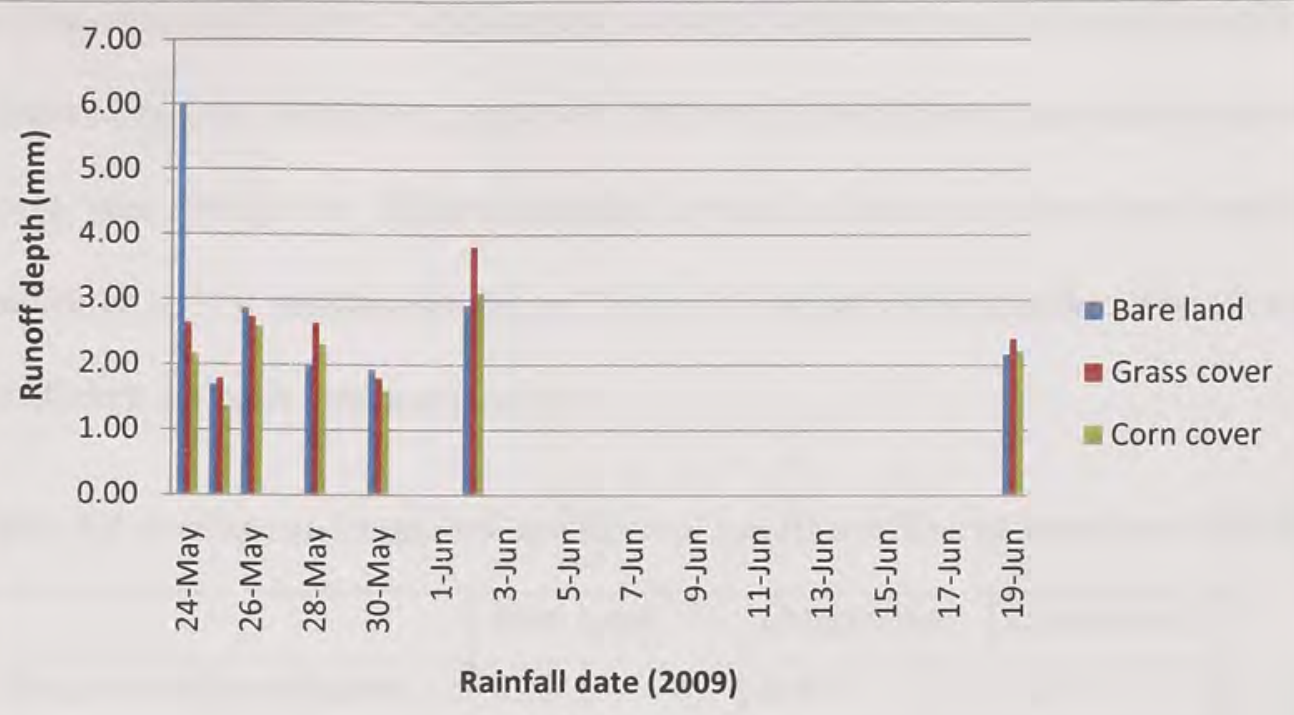

Figure 4.6 Runoff Depth Variations with land use in Amala downstream

The highest average runoff coefficient of 0.45 (ratio of runoff to rainfall), was observed on grass cover and the lowest was 0.35 on cultivated land covered with corn at maturity stage. However, an almost similar runoff coefficient with grass cover, 0.43 , was observed on bare land/cover. For the entire study period, the maximum runoff coefficient, 0.80 in bare land, 0.75 in grass cover and 0.67 in cultivated land/corn cover were observed during the same rainfall event. This rainfall event was not the extreme rainfall amount event thus the reason for such highest observation in runoff coefficient for each land cover may not be runoff amount rather it may be the result of the intensity of rainfall. Rainfall event occurred for a short time with highest intensity. Intense rain may lead to high detachment rates which in turn lead to high sealing effects and also high runoff excess rate with a high runoff coefficient. The lowest coefficient, 0.2 , was observed on bare land/cover and similarly in this event lower runoff coefficient was also observed 
within each land covers. The largest standard deviation on the runoff coefficients was observed on bare land/cover, however, the runoff coefficients that were observed on corn cover was similar in different rainfall events relative to other land uses/covers as evidenced in low standard deviation. Table 4.4 indicated the standard deviations of runoff coefficient for each land use/covers.

Table 4.4 Average and standard deviation of runoff coefficient variations with land uses

\begin{tabular}{|l|l|l|l|}
\hline & Bare land & Grass cover & Corn cover \\
\hline Mean runoff coefficient & 0.43 & 0.45 & 0.35 \\
\hline Standard deviation & 0.23 & 0.22 & 0.17 \\
\hline
\end{tabular}

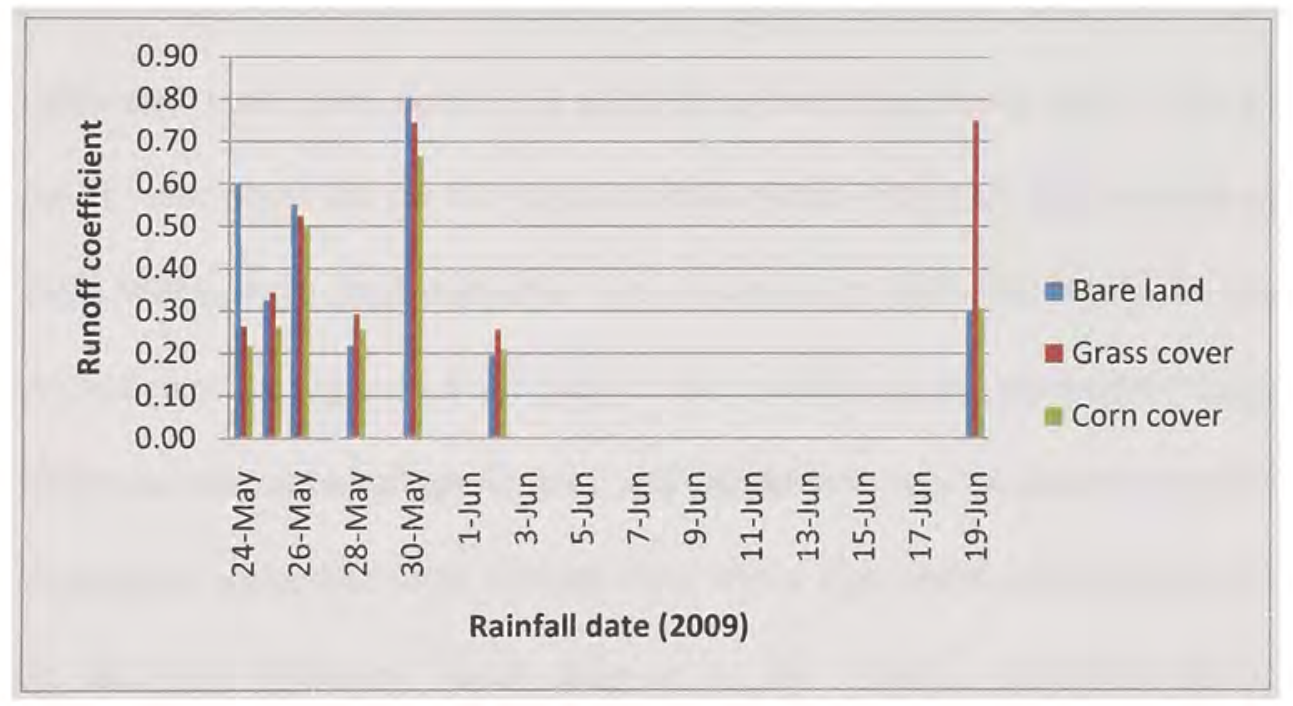

Figure 4.7 Runoff coefficient variations with land use at Amala downstream

4.1.5 Sediment Variations with Land covers in Nyangores watershed.

At the Nyangores site, the highest total sediment yield per unit area was observed on corn cover $162.39 \mathrm{~g} / \mathrm{m}^{2}$ followed by $150.1 \mathrm{~g} / \mathrm{m}^{2}$ and $53.32 \mathrm{~g} / \mathrm{m}^{2}$ on grass cover and bare 
land/cover, respectively. The above result shows that higher sediment yield was observed on corn cover than on bare land/cover. This might be attributed to the cultivation practice that pulverize the soil leading to an increased in sediment yield. . As per the result changing land use/cover from grass cover to bare land/cover may increase soil loss/ sediment yield by $181.6 \%$. Similarly change in land cover from grassland to cultivated land with corn cover may increase sediment yield by $204.5 \%$.

During the study period, the highest sediment yield per unit area of $50 \mathrm{~g} / \mathrm{m}^{2}$ was observed on bare land/cover during the extreme event, and the lowest $0.0 .07 \mathrm{~g} / \mathrm{m}^{2}$ was observed in grass cover. Within each land cover, the highest sediment yield, $45.25 \mathrm{gm} / \mathrm{m}^{2}$ came from cultivated land/ corn cover; $50 \mathrm{~g} / \mathrm{m}^{2}$ from bare land/cover and $17.41 \mathrm{~g} / \mathrm{m}^{2}$ from grass cover were observed on the same rainfall events, however the smallest rate of sediment yield within each land use/cover was observed at different rainfall events (Figure 4.8). As indicated in Figure 4.8 for most of the rainfall events, the highest sediment yield was observed on cultivated land/cover and the lowest was observed on grass cover. In the Nyangores watershed even though there was a significant contribution of extreme events on the total sediment yield, relative to the Amala watershed the extreme events contribution is by far less. As indicated in Table 4.5 below, extreme events contribute $33.3 \%, 32.6 \%$ and $27.9 \%$ of sediment yield to the total sediment yield that was observed on bare land/cover, grass cover and cultivated land covered with corn, respectively. 
Table 4.5 Extreme event percentage contribution of sediment to the total sediment yield

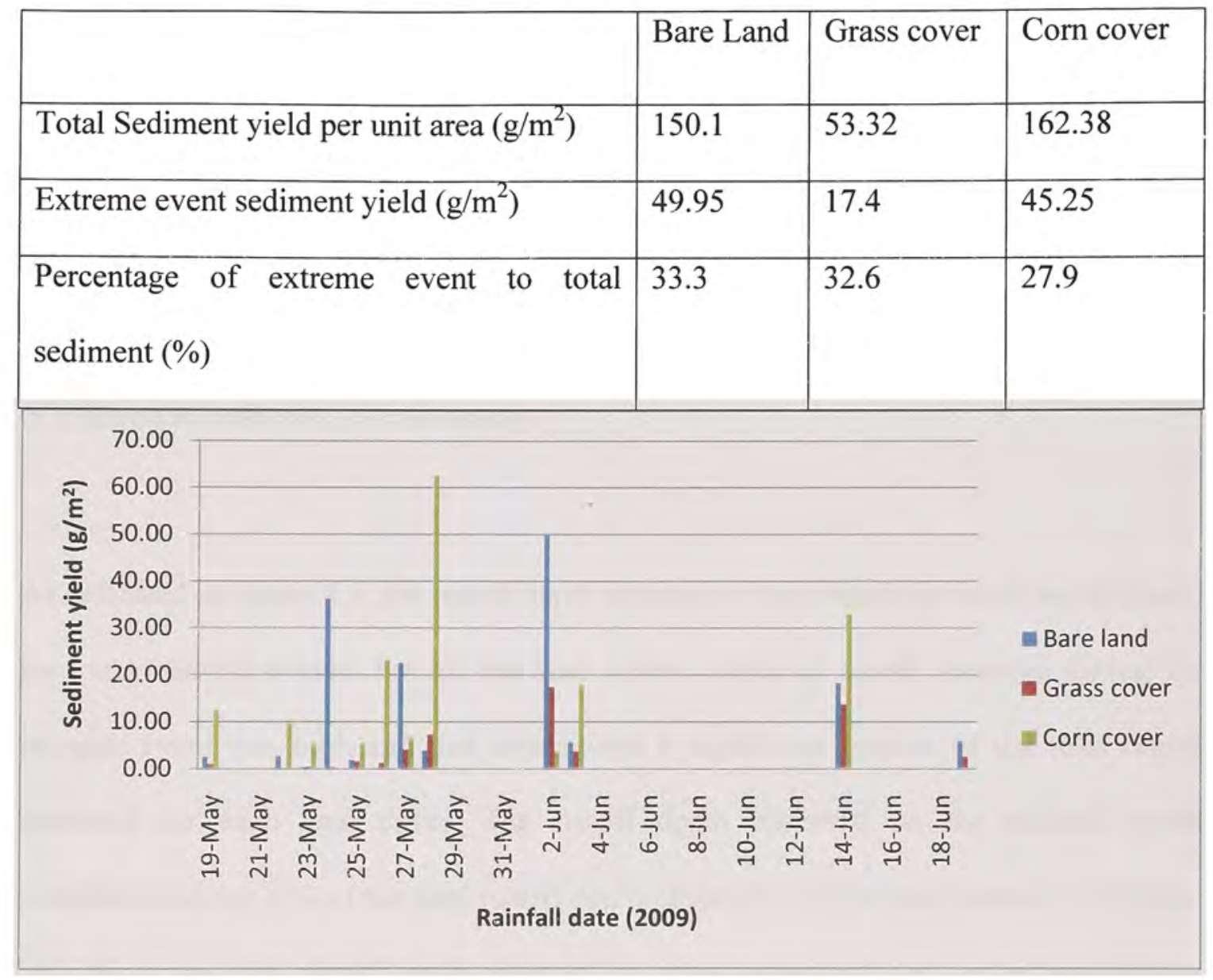

Figure 4.8 Sediment yield variations with land use at Nyangores site

\subsubsection{Runoff variations with land uses in Nyangores watershed}

The runoff depths observed during the research period at different rainfall event varied from $1.20 \mathrm{~mm}$ observed on cultivated land covered with corn to $16.30 \mathrm{~mm}$ that was observed on bare land/cover. The highest total depth of runoff, $44.02 \mathrm{~mm}$ was observed on bare land/cover and $35.7 \mathrm{~mm}$ and $25.02 \mathrm{~mm}$ of total runoff depth during the research period was observed on grass cover and cultivated land covered with corn respectively. 
The total runoff depth observed in bare land/cover was high because of low interception and high in velocity of runoff and little time for water to infiltrate to the soil. The total runoff depth observed from cultivated land with corn cover at maturity was lower than the total depth observed from grass cover as well as bare land/cover. The reason for this may be the higher interception in corn than in grass cover because of the greater in leaf area and the higher in infiltration that results from an increase in macro pores as a result of cultivation/reduction in bulk density.

As indicated in Figure 4.9, the runoff depth response of each land use/cover was different for every rainfall events. For all the land covers, depth of runoff observed during the extreme event was high and that contributed a significant portion of the total runoff observed for each land cover. The runoff depth observed on the extreme event contributed about $37 \%$ of the total runoff depth observed on bare land/covers, $23.5 \%$ and $18.3 \%$ of the total runoff depth observed on grass cover and corn cover respectively (Table 4.6).

Table 4.6 Extreme rainfall events contribution to the total runoff depth during the study period

\begin{tabular}{|l|l|l|l|}
\hline & Bare Land/cover & Grass cover & Corn cover \\
\hline Total runoff depth observed & 44.0 & 35.7 & 25.0 \\
\hline $\begin{array}{l}\text { Runoff depth observed during the } \\
\text { extreme event }\end{array}$ & 16.3 & 8.38 & 4.6 \\
\hline $\begin{array}{l}\text { Percentage contribution of the } \\
\text { extreme event }\end{array}$ & 37.0 & 23.5 & 18.3 \\
\hline
\end{tabular}




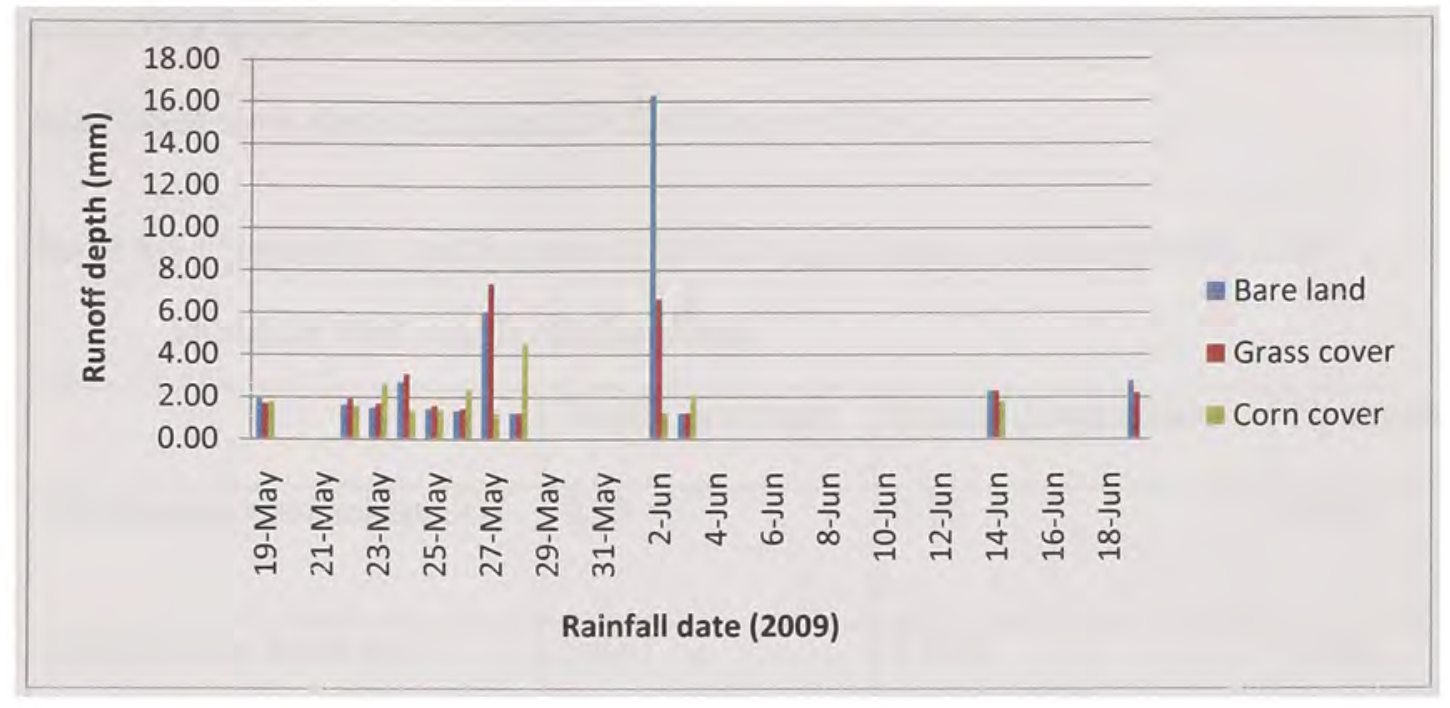

Figure 4.9 Runoff Depth (mm) variations with land uses at Nyangores watershed.

\subsubsection{Correlations between erosion variables}

In this sub-section the significance in the relationships between runoff variables with erosion; rainfall with erosion and rainfall with runoff for three sites and three land covers were evaluated and the results are discussed below.

\subsubsection{Rainfall-Runoff relationships}

The relationships between rainfall and runoff variables were significant for all of the three sites. As indicated in Table 4.7 below for the Amala downstream site the relationship was significant with $\mathrm{r}=0.75$ at $\mathrm{p}=0.03$ and for Amala upstream site $\mathrm{r}=0.76$ with $\mathrm{p}=0.04$, and for Nyangores watershed the relationship was highly significant with $\mathrm{r}$ $=0.79$ at $\mathrm{p}=0.007$. However, similar significant relationships were not observed for all 
land cover types. The relationship between these variables at the Amala downstream bare land/cover were not significant $(r=0.402$ at $p=0.19)$.

Table 4.7 Correlation coefficient values with significance levels for three sites (Rainfall with runoff relationships)

\begin{tabular}{|l|l|l|l|}
\hline & Amala upstream & Amala downstream & Nyangores \\
\hline Correlation coefficient (r) & 0.75 & 0.76 & 0.79 \\
\hline Significance level (p) & 0.030 & 0.040 & 0.007 \\
\hline
\end{tabular}

\subsubsection{Rainfall-Sediment yield relationships}

There were variations in the significance of the relationships between rainfall and sediment yield as a function of the study sites (Table 4.8). The relationships between rainfall and sediment yield were significant for the Amala upstream and Nyangores watershed, but poor relationships were observed for the Amala downstream site. The correlation coefficient (r) values of 0.93 at $p=0.004$ and 0.67 at $p=0.006$ was observed for Amala upstream and Nyangores watershed sites, respectively. However an insignificant correlation coefficient $(r)=-0.06$ at $p=0.41$ was observed for Amala downstream sites. 
Table 4.8 Correlation coefficients (Rainfall with sediment yield) and Significance values for three sites

\begin{tabular}{|l|l|l|l|}
\hline & Amala upstream & Amala downstream & Nyangores \\
\hline Correlation coefficient $(\mathrm{r})$ & 0.93 & -0.06 & 0.67 \\
\hline probability $(\mathrm{p})$ & 0.004 & 0.410 & 0.006 \\
\hline
\end{tabular}

\subsubsection{Runoff with sediment yield relationships}

Similar to rainfall-sediment yield relationships, there were variations in the significance of the relationships between runoff and sediment yield with site (Table 4.9). The relaîionships between runoff and sediment yield were significant for Amala upstream and Nyangores watersheds but poor relationships was observed for the Amala downstream site. Correlation coefficient $(\mathrm{r})$ values of 0.75 at $\mathrm{p}=0.04$ and 0.52 at $\mathrm{p}=0.03$ was observed for the Amala upstream and Nyangores watershed sites, respectively. However poor correlation coefficient $(r)=-0.12$ at $p=0.4$ was observed for the Amala downstream site. The result may vary depend on soil properties. For soil that has high clay content or high silt content and susceptible for sealing the available detached sediment is become small and reduces the amount of sediment transported even though high runoff is available. 
Table 4.9 Correlation coefficients for sediment yield and runoff relationship

\begin{tabular}{|l|c|c|c|}
\hline & Amala upstream & Amala downstream & Nyangores \\
\hline Correlation coefficient (r) & 0.75 & -0.12 & 0.52 \\
\hline Probability (p) & 0.04 & 0.4 & 0.03 \\
\hline
\end{tabular}

4.2 WEPP and Erosion 3D models evaluation

One of the important methods to evaluate the effectiveness of soil erosion models is to compare the predictions given by the model to measured data from soil loss collected on plots taken under natural rainfall conditions (Nearing, 2000). In this study, the Water Erosion Prediction Project (WEPP) model and Erosion 3D models were evaluated following the methods described in the material and methods section and the results are discussed below.

\subsubsection{Water Erosion Prediction Project (WEPP) model}

\subsubsection{Runoff observed and simulated using WEPP}

Significant relationships between observed and simulated runoff values were observed for all of the sites and land covers (Table 4.10). The coefficient of determination $\left(\mathrm{r}^{2}\right)$ values varied from 0.81 for corn cover in Amala upstream to 0.5 for grass cover in Nyangores watershed. The coefficient of determination values of 0.61 and 0.5 was observed in grass covers; 0.81 and 0.77 in corn cover, and 0.59 and 0.79 in bare lands/covers for Amala upstream and Nyangores sites, respectively (Tables 4.10, 4.11 
and 4.12). In the Amala downstream for bare land/cover, the coefficient of determination was not significant; however, when the extreme observation value for the date 2-June, 2009 was excluded from the data set the coefficient of determination was better and statistically significant. On this date, the rainfall observed was the highest (i.e. $14.9 \mathrm{~mm}$ ) and the model overestimated the runoff (Table 4.10). As observed from the results, for high rainfall, the model overestimates and for low rainfall it under estimates. At the Nyangores corn cover site, even though runoff was observed on May, 22 and 23, zero runoff was estimated by the WEPP model which may indicate the model underestimates runoff for low rainfall. Similar result was observed by Zeleke (2000) in the Anjini watershed, Ethiopia.

Table 4. 10 Observed and simulated runoff for different land cover in Amala downstream

\begin{tabular}{|c|c|c|c|c|c|c|}
\hline \multirow[t]{2}{*}{ Date } & \multicolumn{2}{|c|}{ Bare Land/cover } & \multicolumn{2}{|c|}{ Grass cover } & \multicolumn{2}{|c|}{ Corn cover } \\
\hline & $\begin{array}{l}\text { Observed } \\
(\mathrm{mm})\end{array}$ & $\begin{array}{l}\text { Simulated } \\
(\mathrm{mm})\end{array}$ & $\begin{array}{l}\text { Observed } \\
(\mathrm{mm})\end{array}$ & $\begin{array}{l}\text { Simulated } \\
(\mathrm{mm})\end{array}$ & $\begin{array}{l}\text { Observed } \\
(\mathrm{mm})\end{array}$ & $\begin{array}{l}\text { Simulated } \\
(\mathrm{mm})\end{array}$ \\
\hline $\begin{array}{l}\text { 24-May, } \\
2009\end{array}$ & 6.01 & 5.61 & 2.64 & 2.94 & 2.17 & 3.16 \\
\hline $\begin{array}{l}\text { 25-May, } \\
2009\end{array}$ & 1.70 & 1.23 & 1.79 & 2.07 & 1.37 & 1.41 \\
\hline $\begin{array}{l}\text { 26-May, } \\
2009\end{array}$ & 2.87 & 3.38 & 2.73 & 1.89 & 2.59 & 2.00 \\
\hline $\begin{array}{l}\text { 28-May, } \\
2009\end{array}$ & 1.98 & 4.81 & 2.64 & 2.65 & 2.31 & 2.48 \\
\hline $\begin{array}{l}\text { 30-May, } \\
2009\end{array}$ & 1.93 & 2.40 & 1.79 & 1.90 & 1.60 & 1.15 \\
\hline $\begin{array}{l}\text { 19-Jun, } \\
2009\end{array}$ & 2.17 & 3.10 & 2.40 & 2.50 & 2.21 & 2.09 \\
\hline $\begin{array}{l}\text { 2-Jun, } \\
2009^{*}\end{array}$ & 2.92 & 9.19 & 3.82 & 5.20 & 3.11 & 5.90 \\
\hline $\mathrm{R}^{2}$ & \multicolumn{2}{|c|}{$0.52^{*}$} & \multicolumn{2}{|c|}{0.76} & \multicolumn{2}{|c|}{0.67} \\
\hline
\end{tabular}

*calculated excluding the June, 2, 2009 data 
Table 4. 11 Observed and simulated runoff $(\mathrm{mm})$ for different land covers in Amala upstream

\begin{tabular}{|c|c|c|c|c|c|c|}
\hline \multirow[t]{2}{*}{ Date } & \multicolumn{2}{|c|}{ Bare Land/cover } & \multicolumn{2}{|c|}{ Grass cover } & \multicolumn{2}{|l|}{ Corn cover } \\
\hline & Observed & Simulated & Observed & Simulated & Simulated & Observed \\
\hline & 1.93 & 4.55 & 2.28 & 2.91 & 2.26 & 3.32 \\
\hline 28-May, 2009 & 1.93 & 1.12 & 1.88 & 0.70 & 2.21 & 0.97 \\
\hline 28- May, 2009 & 1.98 & 4.73 & 1.98 & 3.26 & 2.26 & 3.55 \\
\hline 1-Jun, 2009 & 2.40 & 3.46 & 1.93 & 1.84 & 2.17 & 2.31 \\
\hline 2-Jun, 2009 & 16.39 & 12.30 & 10.27 & 10.05 & 4.57 & 10.50 \\
\hline 19-Jun, 2009 & 2.21 & 9.18 & 1.79 & 7.19 & 2.73 & 7.57 \\
\hline $\mathrm{R}^{2}$ & \multicolumn{2}{|c|}{0.59} & \multicolumn{2}{|c|}{0.61} & \multicolumn{2}{|c|}{0.81} \\
\hline
\end{tabular}

Table 4.12 Observed and simulated runoff depth $(\mathrm{mm})$ for different land covers at the Nyangores site.

\begin{tabular}{|r|r|r|r|r|r|r|}
\hline \multirow{2}{*}{ Date } & \multicolumn{2}{|c|}{ Bare Land } & \multicolumn{2}{l|}{ Grass cover } & \multicolumn{2}{l|}{ Corn cover } \\
\cline { 2 - 7 } & Observed & Simulated & Observed & simulated & Observed & Simulated \\
\hline 19-May,2009 & 1.93 & 1.33 & 1.70 & 1.32 & - & \\
\hline 22-May, 2009 & 1.65 & 0.67 & 1.93 & 0.00 & 1.79 & 0.00 \\
\hline 23-May,2009 & 1.51 & 1.42 & 1.70 & 0.54 & 1.60 & 0.00 \\
\hline 24-May,2009 & 2.73 & 6.91 & 3.11 & 5.21 & 2.64 & 4.31 \\
\hline 25-May,2009 & 1.46 & 1.33 & 1.60 & 0.18 & 1.37 & 0.81 \\
\hline 26-May,2009 & 1.37 & 4.04 & 1.46 & 1.95 & 1.41 & 1.65 \\
\hline 27-May,2009 & 1.37 & 1.21 & 1.41 & 0.00 & 1.32 & 0.00 \\
\hline 27-May,2009 & 6.08 & 9.07 & 7.39 & 6.61 & 2.36 & 5.31 \\
\hline 2-Jun,2009 & 16.30 & 24.05 & 6.64 & 20.87 & 4.57 & 18.13 \\
\hline 2-Jun,2009 & 2.07 & 2.39 & 1.74 & 0.70 & 1.65 & 0.00 \\
\hline 3-Jun,2009 & 1.24 & 2.51 & 1.24 & 1.32 & 1.23 & 1.25 \\
\hline 14-Jun,2009 & 2.31 & 13.15 & 2.31 & 12.41 & 2.07 & 11.14 \\
\hline 19-Jun,2009 & 2.78 & 6.54 & 2.21 & 3.58 & 1.79 & 3.71 \\
\hline R & 0.79 & & 0.50 & & 0.77 \\
\hline
\end{tabular}




\subsubsection{Sediment yield observed and simulated using WEPP}

As indicated in Table 4.13 below, significant relationships between observed and simulated sediment values were observed for all of the sites and land covers, except the Amala downstream bare land/cover treatment. The coefficient of determination $\left(\mathrm{R}^{2}\right)$ varied from 0.88 for grass cover in Nyangores watershed to 0.2 for bare land/cover in Amala downstream watershed. The Amala downstream runoff as well as erosion was not well simulated by the WEPP model. The reason for this lack of predictive power may be the sealing effect related to the high silt content of the soil that may be related to the dynamic change in soil properties during rainfall event due to sealing. Most available models does not consider dynamic effects of soil properties on runoff and erosion simulation, and this may be the reason for such a poor relationship on the simulated and observed values in the Amala downstream site.

The coefficient of determination $\left(R^{2}\right)=0.72,0.19$ and 0.61 in bare land/cover; $0.79,0.86$ and 0.88 in corn cover; and $0.77,0.72$ and 0.56 in grass cover were observed in Amala downstream, Amala upstream and Nyangores sites, respectively. On bare lands/covers, the model overestimates and underestimates sediment yield for high rainfall events and for low rainfall events, respectively. However, the model underestimates sediment yield for all rainfall in all of the land uses/covers, except bare lands/covers for all sites. At the three sites and for almost all of the observed data in grass cover and cultivated lands/corn covers, the model underestimates sediment and for Nyangores watershed it estimated zero sediment yields for rainfall events less than $5 \mathrm{~mm}$ Table 4.13 . 
Table 4.13 Observed and simulated sediment (gram) variation on three land covers for Amala downstream

\begin{tabular}{|c|c|c|c|c|c|c|}
\hline \multirow[t]{2}{*}{ Date } & \multicolumn{2}{|c|}{ Bare Land/cover } & \multicolumn{2}{|c|}{ Grass cover } & \multicolumn{2}{|c|}{ Corn cover } \\
\hline & Observed & Simulated & Observed & Simulated & Observed & Simulated \\
\hline 24-May, 2009 & 9.89 & 18 & 3.54 & 1 & 9.44 & 3 \\
\hline 25-May, 2009 & 5.91 & 2 & 1.47 & 1 & 3.22 & 1 \\
\hline 26-May, 2009 & 3.15 & 12 & 0.44 & 1 & 0.26 & 0.3 \\
\hline 28-May, 2009 & 24.73 & 16 & 0.05 & 1 & 2.20 & 2 \\
\hline 30-May, 2009 & 19.74 & 10 & 16.93 & 7 & 18.24 & 5 \\
\hline 19-Jun, 2009 & 16.15 & 22 & 5.81 & 2 & 8.96 & $2^{*}$ \\
\hline 2-June, 2009 & 4.33 & 10 & 1.71 & 4 & 6.85 & 2 \\
\hline $\mathrm{R}^{2}$ & & & & & & 86 \\
\hline
\end{tabular}

Table 4.14 Observed and simulated Sediment relationships on three land covers for Amala upstream

\begin{tabular}{|c|c|c|c|c|c|c|}
\hline \multirow[t]{2}{*}{ Date } & \multicolumn{2}{|c|}{ Bare Land/cover } & \multicolumn{2}{|c|}{ Grass cover } & \multicolumn{2}{|c|}{ Corn cover } \\
\hline & Observed & Simulated & Observed & Simulated & Simulated & Observed \\
\hline $\begin{array}{r}26-\text { May, } \\
2009\end{array}$ & 2.67 & 12 & 4.61 & 3 & 10.12 & 6 \\
\hline $\begin{array}{r}\text { 28-May, } \\
2009 \\
\end{array}$ & 6.50 & 4 & 2.47 & 0.1 & 15.51 & 8 \\
\hline $\begin{array}{r}28, \text { May, } \\
2009\end{array}$ & 2.73 & 18 & 2.61 & 3 & 1.91 & 5 \\
\hline 1-Jun, 2009 & 6.82 & 8 & 4.49 & 2 & 9.73 & $\overline{4}$ \\
\hline 2-Jun, 2009 & 56.47 & 34 & 11.00 & 7 & 17.93 & 13 \\
\hline 19-Jun, 2009 & 24.91 & 27 & 10.92 & 5 & 32.89 & 15 \\
\hline $\mathrm{R}^{2}$ & \multicolumn{2}{|c|}{0.} & \multicolumn{2}{|c|}{0.77} & \multicolumn{2}{|c|}{0.79} \\
\hline
\end{tabular}


Table 4.15 Observed and simulated Sediment relationships on three land covers for Nyangores

\begin{tabular}{|c|c|c|c|c|c|c|}
\hline \multirow[t]{2}{*}{ Date } & \multicolumn{2}{|c|}{ Bare Land/cover } & \multicolumn{2}{|c|}{ Grass cover } & \multicolumn{2}{|c|}{ Corn cover } \\
\hline & Observed & Simulated & Observed & Simulated & Observed & Simulated \\
\hline $\begin{array}{r}19- \\
\text { May,2009 } \\
\end{array}$ & 2.54 & 5 & 0.99 & 0 & -...-.--- & --.-- \\
\hline $\begin{array}{r}23- \\
\text { May,2009 } \\
\end{array}$ & 2.69 & 2 & 0.07 & 0 & 12.45 & 0 \\
\hline $\begin{array}{r}24- \\
\text { May,2009 }\end{array}$ & 0.34 & 5 & 0.32 & 0 & 9.67 & 0 \\
\hline $\begin{array}{l}25 \\
\text { May,2009 }\end{array}$ & 36.27 & 16 & 0.42 & 1 & 5.28 & 3 \\
\hline $\begin{array}{r}26- \\
\text { May,2009 }\end{array}$ & 1.90 & 3 & 1.55 & 0 & 0.11 & 1 \\
\hline $\begin{array}{r}27- \\
\text { May,2009 }\end{array}$ & 0.05 & 12 & 1.26 & 0.1 & 5.44 & 1 \\
\hline $\begin{array}{r}27- \\
\text { May, } 2009 \\
\end{array}$ & 2.78 & 4 & 1.70 & 0 & 4.88 & 0.1 \\
\hline 2-Jun, 2009 & 19.77 & 25 & 2.35 & 3 & 18.32 & 6 \\
\hline 2-Jun,2009 & 38.79 & 41 & 12.59 & 12 & 41.65 & 30 \\
\hline 3-Jun,2009 & 11.17 & 6 & 4.82 & 0.1 & 20.93 & 0.1 \\
\hline 14-Jun, 2009 & 5.67 & 10 & 3.70 & 0.1 & 3.59 & 0 \\
\hline 19-Jun, 2009 & 18.31 & 9.6 & 13.71 & 11 & 17.90 & 26 \\
\hline $\begin{array}{l}22- \\
\text { May,2009 }\end{array}$ & 5.94 & 15 & 2.58 & 1 & 32.97 & 13 \\
\hline $\mathrm{R}^{2}$ & 0. & & & & & \\
\hline
\end{tabular}




\subsubsection{Runoff simulated and observed using Erosion 3D/2D}

As indicated in Table 4.16 below, significant relationships between observed and simulated runoff values were observed for all of the sites and land covers. The model underestimates runoff for most of the observations for the Amala downstream site. Highly significant relationships between the observed and estimated runoff depth was observed for all sites and land covers except for Amala upstream cultivated land/corn cover. For the Nyangores site, correlation coefficients of $0.74(p=0.0004), 0.84(p=$ $0.0003)$ and $0.84(p=0.0006)$ were found for bare land/cover, grass cover and cultivated land/ corn cover, respectively.

For the Amala upstream site, the low correlation coefficient was calculated between the observed and estimated runoff depth, however, excluding the observation on May 24, 2009 improved the coefficient. The relationship between the observed and simulated runoff depth is also significant at the Amala upstream site with a correlation coefficient of 0.82 and p-value of 0.02 . 
Table 4.16 Observed and simulated runoff depth relationships on three land covers for Amala downstream.

\begin{tabular}{|c|c|c|c|c|c|c|}
\hline \multirow[t]{2}{*}{ Date } & \multicolumn{2}{|c|}{ Bare cover } & \multicolumn{2}{|c|}{ Grass cover } & \multicolumn{2}{|c|}{ Corn cover } \\
\hline & Observed & Simulated & Observed & Simulated & Observed & Simulated \\
\hline $\begin{array}{l}\text { 24-May, } \\
2009^{*}\end{array}$ & 6.01 & 2.11 & 2.64 & 1.94 & 2.17 & 1.96 \\
\hline $\begin{array}{l}\text { 25-May, } \\
2009\end{array}$ & 1.70 & 1.56 & 1.79 & 1.37 & 1.37 & 1.42 \\
\hline $\begin{array}{l}\text { 26-May, } \\
2009\end{array}$ & 2.87 & 1.94 & 2.73 & 1.89 & 2.59 & 1.91 \\
\hline $\begin{array}{l}\text { 28-May, } \\
2009\end{array}$ & 1.98 & 1.78 & 2.64 & 1.53 & 2.31 & 1.56 \\
\hline $\begin{array}{l}\text { 30-May, } \\
2009\end{array}$ & 1.93 & 1.84 & 1.79 & 1.61 & 1.60 & 1.64 \\
\hline 19-Jun, 2009 & 2.17 & 1.98 & 2.40 & 1.91 & 2.21 & 1.95 \\
\hline 2-June, 2009 & 2.92 & 2.44 & 3.82 & 2.4 & 3.11 & 2.33 \\
\hline $\begin{array}{l}\text { Coefficient } \\
\text { of correlation }\end{array}$ & \multicolumn{2}{|c|}{$0.82^{*}$} & \multicolumn{2}{|c|}{0.87} & \multicolumn{2}{|c|}{0.85} \\
\hline $\begin{array}{l}\text { Probability } \\
\text { (p) }\end{array}$ & \multicolumn{2}{|c|}{0.022} & \multicolumn{2}{|c|}{0.01} & \multicolumn{2}{|c|}{0.015} \\
\hline
\end{tabular}

* Data excluded from $r$ computation.

Table 4.17 Observed and simulated runoff depth relationships on three land covers for Amala upstream

\begin{tabular}{|c|c|c|c|c|c|c|}
\hline \multirow[t]{2}{*}{ Date } & \multicolumn{2}{|c|}{ Bare Cover } & \multicolumn{2}{|c|}{ Grass cover } & \multicolumn{2}{|c|}{ Corn cover } \\
\hline & Observed & Simulated & Observed & Simulated & Simulated & Observed \\
\hline $\begin{array}{l}\text { 26-May, } \\
2009\end{array}$ & 1.93 & 1.93 & 2.28 & 1.6 & 1.77 & 3.32 \\
\hline $\begin{array}{l}\text { 28-May, } \\
2009\end{array}$ & 1.93 & 2.01 & 1.88 & 1.96 & 2 & 0.97 \\
\hline $\begin{array}{l}28, \text { May, } \\
2009\end{array}$ & 1.98 & 2.45 & 1.98 & 0.76 & 0.87 & 3.55 \\
\hline 1-Jun, 2009 & 2.40 & 1.71 & 1.93 & 1.38 & 1.44 & 2.31 \\
\hline 2-Jun, 2009 & 16.39 & 10.13 & 10.27 & 7.78 & 8.57 & 10.50 \\
\hline $\begin{array}{l}\text { 19-Jun, } \\
2009\end{array}$ & 2.21 & 2.78 & 1.79 & 2.58 & 2.67 & 7.57 \\
\hline $\begin{array}{l}\text { Correlation } \\
\text { coefficient }\end{array}$ & \multicolumn{2}{|c|}{0.99} & \multicolumn{2}{|c|}{0.98} & \multicolumn{2}{|c|}{0.85} \\
\hline $\begin{array}{l}\text { Probability } \\
\text { (p) }\end{array}$ & \multicolumn{2}{|c|}{0.0001} & \multicolumn{2}{|c|}{0.0006} & \multicolumn{2}{|c|}{0.106} \\
\hline
\end{tabular}


Table 4.18 Observed and simulated runoff depth relationships on three land covers for Nyangores watershed

\begin{tabular}{|c|c|c|c|c|c|c|}
\hline \multirow[t]{2}{*}{ Date } & \multicolumn{2}{|c|}{ Bare cover } & \multicolumn{2}{|c|}{ Grass cover } & \multicolumn{2}{|c|}{ Corn cover } \\
\hline & Observed & Simulated & Observed & simulated & Observed & Simulated \\
\hline 19-May,2009 & 1.93 & 1.12 & 1.70 & 0.9 & - & - \\
\hline 22-May,2009 & 1.65 & 0.6 & 1.93 & 0.39 & 1.79 & 0.5 \\
\hline 23-May,2009 & 1.51 & 1.18 & 1.70 & 1 & 1.60 & 1.1 \\
\hline 24-May,2009 & 2.73 & 1.74 & 3.11 & 1.44 & 2.64 & 1.62 \\
\hline $\begin{array}{l}25- \\
\text { May,2009 }\end{array}$ & 1.46 & 0.81 & 1.60 & 0.59 & 1.37 & 0.7 \\
\hline 26-May,2009 & 1.37 & 1.53 & 1.46 & 1.3 & 1.41 & 1.44 \\
\hline 27-May, 2009 & 1.37 & 0.57 & 1.41 & 0.45 & 1.32 & 0.57 \\
\hline 27-May,2009 & 6.08 & 2.03 & 7.39 & 2.8 & 2.36 & 1.92 \\
\hline 2-Jun,2009 & 16.30 & 3.93 & 6.64 & 3.72 & 4.57 & 3.89 \\
\hline 2-Jun,2009 & 2.07 & 0.99 & 1.74 & 0.76 & 1.65 & 0.88 \\
\hline 3-Jun,2009 & 1.24 & 1.73 & 1.24 & 1.5 & 1.23 & 1.61 \\
\hline 14-Jun, 2009 & 2.31 & 3.3 & 2.31 & 2.18 & 2.07 & 2.3 \\
\hline 19-Jun,2009 & 2.78 & 2.03 & 2.21 & 1.8 & 1.79 & 1.92 \\
\hline $\begin{array}{l}\text { Correlation } \\
\text { coefficient }\end{array}$ & 0. & & & & 0. & \\
\hline $\begin{array}{l}\text { Probability } \\
\text { (p) }\end{array}$ & 0.0 & 04 & & 003 & & 006 \\
\hline
\end{tabular}


4.2.2.2 Sediment yield observed and simulated using Erosion 3D

As shown in Table 4.19, the relationships between simulated and observed sediment yield were highly significant for all sites and land cover except for the Amala downstream bare land/cover site. The model underestimates for almost all of the observations in all of the sites and land covers.

Even though different researchers such as Jetten et al. (1999) observed overestimation of the model at a watershed scale, in this study the underestimation of the model may be the result of the low rainfall amounts observed during the study period. Thus the model may underestimate for low rainfall events and overestimates for normal and high rainfall events. For the Amala downstream site, correlation coefficients of 0.96 at $p=0.0006$ and 0.95 at $\mathrm{p}=0.001$ were observed for grass cover and cultivated lands/corn cover respectively (Table 4.20). However, the correlation coefficient observed for bare land/cover in the Amala downstream was not significant. The strongest significant correlation between the observed and simulated values was observed for Nyangores watershed. At this site, the correlation coefficients of 0.81 at probability value of 0.002 , 0.91 at $\mathrm{p}=0.0004$ and 0.88 at $\mathrm{p}=0.0002$ were observed for bare land/cove, grass cover and cultivated land/corn cover, respectively (Table 4.21). 
Table 4.19 Observed and simulated sediment variation on three land covers for Amala downstream.

\begin{tabular}{|c|c|c|c|c|c|c|}
\hline \multirow[t]{2}{*}{ Date } & \multicolumn{2}{|c|}{ Bare Land/cover } & \multicolumn{2}{|c|}{ Grass cover } & \multicolumn{2}{|c|}{ Corn cover } \\
\hline & Obscrived & Simulated & Observed & Simulated & Observed & $\begin{array}{l}\text { Simulat } \\
\text { ed }\end{array}$ \\
\hline 24-May, 2009 & 9.89 & 3 & 3.54 & 0 & 9.44 & 4 \\
\hline 25-May, 2009 & 5.91 & 0 & 1.47 & 0 & 3.22 & 0 \\
\hline 26-May, 2009 & 3.15 & 1 & 0.44 & 1 & 0.26 & 0 \\
\hline 28-May, 2009 & 24.73 & 0 & 0.05 & 0 & 2.20 & 0 \\
\hline 30-May, 2009 & 19.74 & 5 & 16.93 & 8 & 18.24 & 11 \\
\hline 19-Jun, 2009 & 16.15 & 2 & 5.81 & 2 & 8.96 & 3 \\
\hline 2-June, 2009 & 4.33 & 0 & 1.71 & 1 & 6.85 & 5 \\
\hline $\begin{array}{l}\text { Coefficient of } \\
\text { correlation }\end{array}$ & \multicolumn{2}{|c|}{0.34} & \multicolumn{2}{|c|}{0.96} & \multicolumn{2}{|c|}{0.95} \\
\hline Probability (p) & \multicolumn{2}{|c|}{0.455} & \multicolumn{2}{|c|}{0.0006} & \multicolumn{2}{|c|}{0.001} \\
\hline
\end{tabular}

Table 4.20 Observed and simulated sediment relationships on three land covers for Amala up stream

\begin{tabular}{|c|c|c|c|c|c|c|}
\hline \multirow[t]{2}{*}{ Date } & \multicolumn{2}{|c|}{ Bare Land/cover } & \multicolumn{2}{|c|}{ Grass cover } & \multicolumn{2}{|c|}{ Corn cover } \\
\hline & Observed & Simulated & Observed & Simulated & Simulated & $\begin{array}{l}\text { Obser } \\
\text { ved }\end{array}$ \\
\hline 26-May, 2009 & 2.67 & 0 & 4.61 & 0 & 10.12 & 0 \\
\hline 28-May, 2009 & 6.50 & 0 & 2.47 & 0 & 15.51 & 0 \\
\hline 28, May, 2009 & 2.73 & 1 & 2.61 & 0 & 1.91 & 0 \\
\hline 1-Jun, 2009 & 6.82 & 0 & 4.49 & 0 & 9.73 & 1 \\
\hline 2-Jun, 2009 & 56.47 & 11 & 11.00 & 3 & 17.93 & 9 \\
\hline 19-Jun, 2009 & 24.91 & 8 & 10.92 & 2 & 32.89 & 11 \\
\hline $\begin{array}{l}\text { Correlation } \\
\text { coefficient }\end{array}$ & \multicolumn{2}{|c|}{0.95} & \multicolumn{2}{|c|}{0.95} & \multicolumn{2}{|c|}{0.84} \\
\hline $\begin{array}{r}\text { Probability } \\
\text { (p) }\end{array}$ & \multicolumn{2}{|c|}{0.0036} & \multicolumn{2}{|c|}{0.0036} & \multicolumn{2}{|c|}{0.036} \\
\hline
\end{tabular}


Table 4.21 Observed and simulated sediment relationships on three land covers for Nyangores

\begin{tabular}{|c|c|c|c|c|c|c|}
\hline \multirow[t]{2}{*}{ Date } & \multicolumn{2}{|c|}{ Bare Land/cover } & \multicolumn{2}{|c|}{ Grass cover } & \multicolumn{2}{|c|}{ Corn cover } \\
\hline & Observed & Simulated & Observed & Simulated & Observed & Simulated \\
\hline $\begin{array}{r}22- \\
\text { May, } 2009\end{array}$ & 2.54 & 0 & 0.99 & 0 & 12.45 & 0 \\
\hline $\begin{array}{r}23- \\
\text { May,2009 }\end{array}$ & 2.69 & 0 & 0.07 & 0 & 9.67 & 0 \\
\hline $\begin{array}{r}24- \\
\text { May,2009 }\end{array}$ & 0.34 & 0 & 0.32 & 0 & 5.28 & 0 \\
\hline $\begin{array}{r}25- \\
\text { May,2009 }\end{array}$ & 36.27 & 2 & 0.42 & 0 & 0.11 & 0 \\
\hline $\begin{array}{r}26- \\
\text { May,2009 }\end{array}$ & 1.90 & 0 & 1.55 & 0 & 5.44 & 0 \\
\hline $\begin{array}{r}27- \\
\text { May,2009 }\end{array}$ & 0.05 & 0 & 1.26 & 1 & 4.88 & 1 \\
\hline $\begin{array}{r}27- \\
\text { May,2009 }\end{array}$ & 2.78 & 0 & 1.70 & 0 & 18.32 & 0 \\
\hline 2-Jun,2009 & 19.77 & 2 & 2.35 & 1 & 41.65 & 7 \\
\hline 2-Jun,2009 & 38.79 & 9 & 12.59 & 3 & 20.93 & 2 \\
\hline 3-Jun,2009 & 11.17 & 0 & 4.82 & 0 & 3.59 & 1 \\
\hline 14-Jun, 2009 & 5.67 & 0 & 3.70 & 0 & 17.90 & 2 \\
\hline 19-Jun, 2009 & 18.31 & 1 & 13.71 & 5 & 32.97 & 4 \\
\hline $\mathrm{R}^{2}$ & & & 0. & 91 & & \\
\hline $\begin{array}{l}\text { Probability } \\
\text { (p) }\end{array}$ & 0.0 & & 0.00 & 0004 & & \\
\hline
\end{tabular}




\subsection{Application of erosion 3D at the watershed scale}

In this section, the total erosion rate, the sediment budget and runoff distribution in the Mara River basin and the variations of these variables with land use/land covers will be discussed. Moreover, the relationships of these variables with soil types and slope steepness are discussed.

\subsubsection{Erosion in the Mara River basin}

The model suggested that the mean annual erosion in the Mara River basin was about 31 ton/ha, which is about $3 \mathrm{~kg} / \mathrm{m}^{2}$. The result indicated that there is about $2 \mathrm{~mm}$ of mean annual soil removal from the watershed. Bennett (1939) as cited from El-Saify et al. (1982), indicated that tillage operation probably increase the rate of topsoil renewal to about $30 \mathrm{yr} / \mathrm{cm}$. This rate is nearly equivalent to $11 \mathrm{ton} / \mathrm{ha} / \mathrm{yr}$, which is usually taken us the upper limit for tolerable soil loss in the US; Bennett (1939) indicated that information is lacking on tolerance limit in the tropics, however, the high rate of weathering associated with tropical climates may leads to high soil regeneration rates, that may favor high tolerance limit.

As per the model estimate, average rate of soil erosion rate in the Mara River basin is by far greater than the upper limit of the tolerable soil erosion rate $(11 \mathrm{ton} / \mathrm{ha} / \mathrm{yr})$ but less erosion rate was also estimated in different land uses. Even though the mean annual soil removal from the entire watershed is high relative to the tolerable limit, extremely high amounts of erosion were also observed in different land uses, as shown from the higher 
standard deviation that was observed in the watershed and in the spatial soil erosion distribution map as indicated below in Figure 4.10. High standard deviation, about 36 ton/ha, in the estimated erosion rate was observed and the reason for such variation in the mean erosion rate with area may be the variation in the rate of erosion with land uses, slope steepness and soil types.

\subsubsection{Erosion variation with land uses}

As indicated in Figure 4.10, the erosion distribution and erosion hazard areas in the Mara River basin had relationship with the distribution of land uses (Figure 3.3). The least mean annual erosion rate of 3 ton/ha is removed annually from grassland. As indicated in Figure 4.10 , the rate of erosion in grasslands distributed from 0 to 16 tons $/ \mathrm{ha}$, and an increased in erosion rate was observed with change in slope steepness within the land use. In the grassland, erosion was too small and less than the mean annual erosion rate of the entire river basin.

Moreover, in grassland as evidenced from the calculated standard deviation (Table 4.22), the variation in erosion rate within different sites of this land use was the smallest, 4 ton/ha. The reason for such small calculated standard deviation may be to the result of the little variation in other erosion factors such as slope steepness and soil types within the land use. As shown in the land use-slope steepness distribution, in Appendix Table 4, almost $99 \%$ of the grassland is located in slope between 0 to $10^{\circ}$, this may be the reason for least standard deviation in erosion rate to be observed in this land use. 
The highest erosion rate was obtained from cultivated lands. The mean annual rate of erosion per unit area in cultivated lands was about $120 \mathrm{tons} / \mathrm{ha} / \mathrm{yr}$, which is equivalent to $12 \mathrm{~kg}$ per square meter per year of erosion. The rate of erosion on agricultural land is about ten times more than the mean annual soil erosion rate of the basin. Moreover high standard deviation in erosion rate was observed on this land use type and this indicated that there is high variation in erosion within the land use. As indicated in Figure 4.10, the rate of soil erosion varied in this land use from 16 tons/ ha to the maximum of 169 tons/ha/yr. Table 4.22 below also shows that $7 \mathrm{ton} / \mathrm{ha} / \mathrm{yr}$ and $11 \mathrm{~kg} / \mathrm{ha} / \mathrm{yr}$ rate of soil erosion was estimated from bush land and forest lands, respectively. The mean annual erosion rate in the forest land varied from 3 tons/ha to 16 tons/ha. The effect of land use change on erosion rate can be easily observed, on forest land and cultivated land that are located in the upstream side of the watershed. On the upstream side of the basin both the land uses (forest and cultivated lands) are located in similar slope steepness (Appendix Table 3) and soil type (Figure 3.3), however, because of differences in land uses rate of erosion on cultivated land is by far higher than the rate from forest land. 


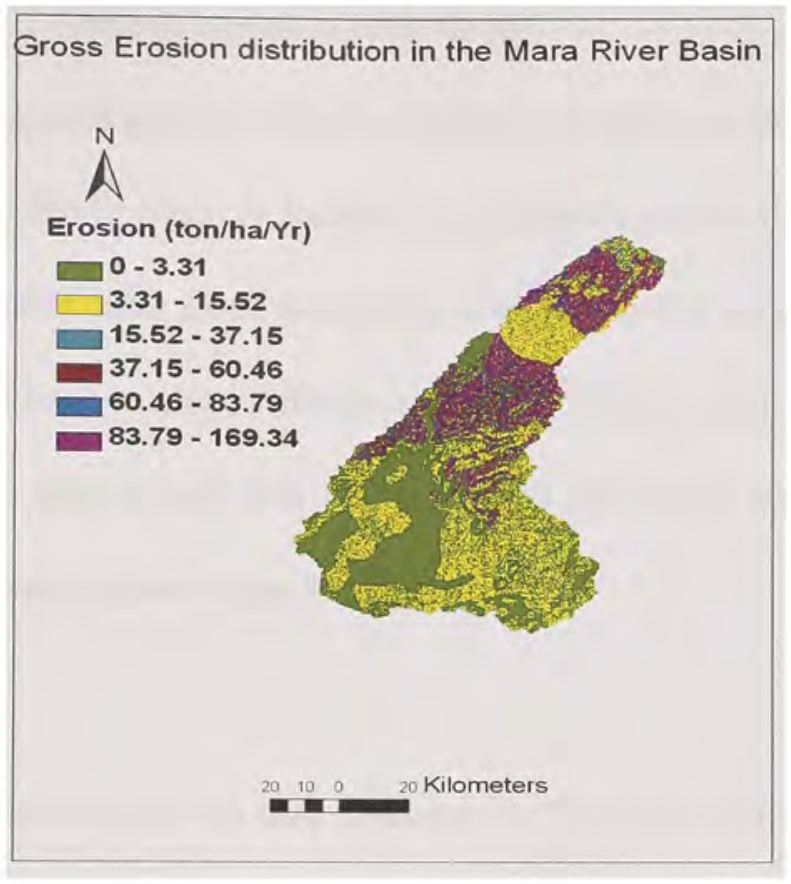

Figure 4.10 Erosion distributions in Mara River basin

Table 4.22 Erosion variation with land uses in the Mara River basin

\begin{tabular}{|l|r|}
\hline $\begin{array}{l}\text { Mean annual erosion per unit area (t/ha) for the entire } \\
\text { watershed }\end{array}$ & 31 \\
\hline \multicolumn{2}{|c|}{ Erosion in forest Land } \\
\hline $\begin{array}{l}\text { Mean Annual erosion per unit area } \\
\text { standard deviation in erosion }\end{array}$ & 11 \\
\hline \multicolumn{2}{|c|}{ Erosion in grass land } \\
\hline $\begin{array}{l}\text { Mean Annual erosion per unit area } \\
\text { standard deviation in erosion }\end{array}$ \\
\hline \multicolumn{2}{|c|}{ Erosion in bush land } \\
\hline $\begin{array}{l}\text { Mean Annual erosion per unit area } \\
\text { standard deviation in erosion }\end{array}$ \\
\hline \multicolumn{2}{|c|}{ Erosion in cultivated land } \\
\hline Mean Annual erosion per unit area \\
standard deviations in erosion \\
\hline \multicolumn{2}{|c|}{ Erosion Land use wood land } \\
\hline Mean Annual erosion per unit area \\
standard deviation in erosion \\
\hline
\end{tabular}


4.3.1.2 Erosion variation with slope

The spatial map of slope in Figure 4.11 indicates that most of the downstream area of the Mara River basin is located an area with gentle slopes, (0 to 6\%) steepness, and in the upstream area slope steepness is higher and it ranges from 13 to $77 \%$. Erosion hazard areas have relation with the spatial variation in slope steepness, as indicated in Table 4.23 mean annual soil loss rate about 60 tons/ha/yr was estimated on areas that has slope steepness greater than 30 degree.

The lowest erosion rate estimated in the river basin is on areas that have slope steepness less than $3^{\circ}$. Along this slope the mean annual soil loss was 2 tons $/$ ha/yr. For areas that have slope steepness between 3 to 10 degrees, the mean annual erosion rate was about 5 tons/ha/yr. For slope ranges between 10 to 20 , degrees the mean annual erosion rate increased significantly and the estimated rate was 31 tons/ha/year. Similarly, significant increment in erosion rate was estimated for slope steepness ranges from 20 to $30^{\circ}$, which was about 55.51 tons $/$ ha/yr. For slope greater than 30 degrees, there was no significant increment in mean erosion rate compared to the 20 to $30^{\circ}$ slope ranges. As indicated in the table below, the range between the maximum mean erosion rate and the minimum mean erosion rate in different ranges of slope steepness was about 58 tons/ha/yr and this range relative to the range that was observed in different land uses was small. The mean erosion rate difference between the maximum and the minimum rate in different land uses was about 116 tons/ha/yr, which is the difference between mean erosion rate (120 ton/ha) from agricultural lands and erosion rate about 4 ton/ha from grasslands. This 
variation may indicate that the most determinant factor for the variation in erosion rate in the Mara River basin was the change in land use rather than the change in topography. However, as indicated in the slope spatial map in Figure 4.11 and in the land use map in Figure 3.3, most of the cultivated lands in the Mara River basin is located in relatively steep slopes and this may be one of the reason for extremely high erosion rate to be observed on agricultural land in addition to its pulverizing effect.

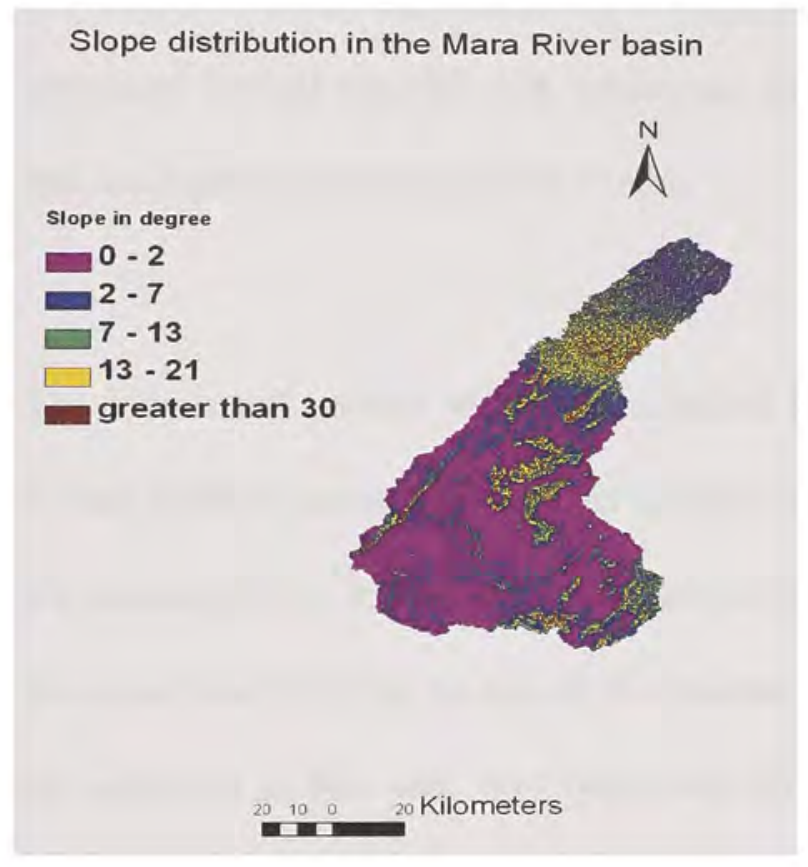

Figure 4.11 Slope (degrees) distribution map in the Mara River basin

Table 4.23 Slope distribution erosion variation in the Mara River basin

\begin{tabular}{|c|l|}
\hline Slope (Degree) & Mean Erosion Rate (ton/ha/yr) \\
\hline less than 3 & 2 \\
\hline 3 to 10 & 5 \\
\hline 10 to 20 & 31 \\
\hline 20 to 30 & 56 \\
\hline greater than 30 & 60 \\
\hline
\end{tabular}




\subsubsection{Erosion variation with soil types}

Soil physical and chemical properties have impact on the rate of soil erosion, in the study area. The highest mean erosion rate of about 190 tons/ha/yr was observed for soils that have high silt and low clay contents. The lower erosion rate (less than 10 tons/ha/yr) was observed for soils that has clay content more than $40 \%$. However, the rate of erosion in each soil types varied with slope steepness and land uses, which means with the spatial distribution of soil types. As shown in Table 4.24, the highest soil erosion rate was estimated for soil type KE 378 , which has the lowest percentages, $15 \%$, of clay content and the highest percentage, $70 \%$ of silts.

The lowest soil erosion was also estimated for soil type code KE 388, which has the second highest percentages of sand content, $60 \%$, and the second lowest percentages of silt content, $20 \%$. In this soil, as shown in Table 4.24 , the mean runoff depth estimated was small and this may be one of the reasons for the estimated low mean erosion rate to be estimated in this soil. Soil type code KE 190 has the highest percentage of sand content, $62 \%$, and low erosion was estimated for this soil. As evidenced from the runoff distribution with soil type in Table 4.24; low runoff depth was estimated in this soil and this may be the reason for low erosion to be estimated in this soil. The reason for this may be the lower percentage of sand content, $10 \%$, as evidenced from Table 4.24, and this may lead to high reduction in infiltration which in turn may increases runoff rate and erosion. 
Significant relationships between the different particle size distributions and erosion rate was also observed. Erosion rate has negative relationships with sand and clay contents, the negative $r$ value indicated that the increment in sand and clay particles leads to reduction in mean annual erosion rate. Significant correlation, $r=-0.54$ at $p=0.001$ was observed for sand particle size relationships with erosion rate excluding KE 391 soil type, however, the relationship between clay particle and erosion rate was not significant, but negative directional relationship as described above was observed. Positive relationship between silt particle size content and erosion rate was observed. The correlation coefficient, $r$ value 0.76 at $p=0.0001$ was observed for silt contents relationships with mean annual erosion rate. This correlation coefficient indicated that erosion rate increases with increase in silt content; the reason is that the silt particle is susceptible for detachment and can be easily transported because of its small mass. As shown in Appendix Figure 2 and Figure 4.12, the silt particle size content of the soils (\%) had relation with the erosion distribution in the watershed. However, an increase in erosion rate with silt content was not observed for all soil types, low erosion rate was observed for soil type KE45, which had high silt content (67\%).

Table. 4. 24 Particle size relationship with erosion rate

\begin{tabular}{|c|l|}
\hline Particle size & Correlation coefficient \\
\hline Silt & 0.75 \\
\hline Sand & -0.51 \\
\hline Clay & -0.36 \\
\hline
\end{tabular}


In order to evaluate the interaction effect of slope steepness-land use and soil type on soil erosion, different soil code was given to soils that have the same textural classification based on their slope and land use cover. As shown in Table 4.25 below soil type code KE 391, 392, 393, 394 and 395 has the same sand, silt and clay percentage distribution and the only difference is the land cover and slope steepness on which they located. The model estimation indicated that in this soil mean annual erosion rate varied from 4 ton/ha/yr to 75 ton/ha/yr. Soil types KE 391 and 392 were located in cultivated land which is covered by annual crops. However the rest of the soils were covered by grass or bush and located in gentle slopes as a result mean erosion rate estimated was low. This result may indicate that susceptibility of a soil to erosion may significantly change due to change in other erosion factors such as slope steepness and cover.

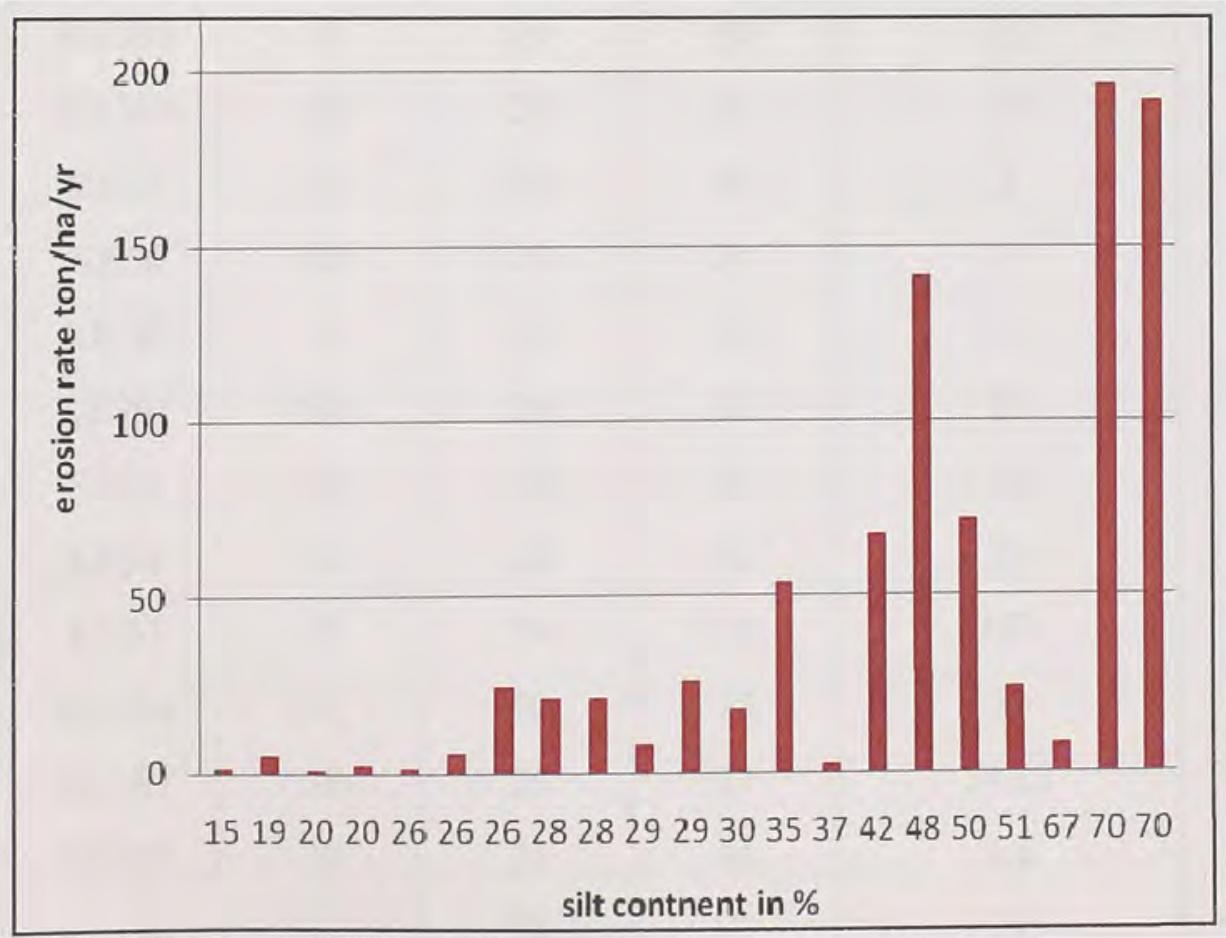

Figure 4.12 Silt particle size content and erosion rate distribution 
Table.4.25 Soil type, particle size and mean annual erosion rate in the Mara River basin

\begin{tabular}{|c|c|c|c|c|}
\hline $\begin{array}{l}\text { Soil type } \\
\text { code }\end{array}$ & clay $\%$ & silt $\%$ & sand $\%$ & $\begin{array}{c}\text { erosion } \\
\text { rate(ton/ha/yr) }\end{array}$ \\
\hline KE200 & 31 & 29 & 40 & 8 \\
\hline KE377 & 58 & 26 & 16 & 7 \\
\hline KE196 & 42 & 42 & 16 & 68 \\
\hline KE380 & 21 & 26 & 53 & 1 \\
\hline KE378 & 15 & 70 & 15 & 197 \\
\hline KE382 & 25 & 51 & 24 & 24 \\
\hline KE381 & 58 & 26 & 16 & 4 \\
\hline KE385 & 40 & 15 & 45 & 1 \\
\hline KE383 & 33 & 37 & 30 & 2 \\
\hline KE384 & 58 & 26 & 16 & 4 \\
\hline KE386 & 41 & 29 & 30 & 26 \\
\hline KE387 & 58 & 26 & 16 & 5 \\
\hline KE388 & 20 & 20 & 60 & 0.2 \\
\hline KE389 & 58 & 26 & 16 & 75 \\
\hline KE57 & 35 & 20 & 45 & 2 \\
\hline KE56 & 60 & 19 & 21 & 5 \\
\hline $\mathrm{KE} 45$ & 9 & 67 & 24 & 8 \\
\hline KE391 & 58 & 26 & 16 & 33 \\
\hline KE61 & 20 & 30 & 50 & 18 \\
\hline KE58 & 32 & 28 & 40 & 21 \\
\hline KE93 & 15 & 70 & 15 & 192 \\
\hline KE194 & 22 & 50 & 28 & 72 \\
\hline KE187 & 38 & 35 & 27 & 54.13 \\
\hline KE183 & 30 & 26 & 44 & 5.6 \\
\hline KE190 & 10 & 28 & 62 & 21 \\
\hline KE192 & 20 & 48 & 32 & 142 \\
\hline
\end{tabular}




\subsubsection{Sediment budget in Mara River basin}

In the above section, the total mean erosion rate variation with slope, soil and land use/land cover was discussed. However, total erosion rate does not show the rate at which sediment leaves an area; it only shows the rate of sediment detachment from specific area. The actual rate of sediment loss an area may experience depends on the transport capacity of the erosive agent and the available detached sediment. To determine the rate of net erosion, which is sediment leave from an area, rate of deposition may need to be estimated and deducted from the total erosion rate.

Figure 4.13 shows the net sediment transported and deposited from an area within the watershed. The negative sign indicates the rate at which sediment left from an area and the positive indicates the rate of deposition in an area; average annual sediment transported from most of agricultural lands ranged from 1.86 to $6.14 \mathrm{~kg}$ per meter square area. In the upstream side of the watershed, where slope steepness is high and the land use is agriculture, sediment left from this area at an average rate of $8 \mathrm{~kg}$ per square meter, however from the total agricultural lands sediment transported at an average rate of about $6 \mathrm{~kg}$ per square meter. Compared to the average soil erosion rate, which is $12 \mathrm{~kg}$ per meter square, in this land use, the sediment transported is about $50 \%$ of the total erosion rate. The lowest amount of sediment transported, which is less than $2 \mathrm{~kg}$ per square meter were observed on forest lands and grasslands and the highest erosion rate was observed on agricultural land with steep slope. In agricultural lands with steep slope areas, an erosion rate varied from 6 to $12 \mathrm{~kg}$ per square meter. 
Figure 4.13 indicates that the spatial distribution of sediment deposited with in the Mara River basin and it clearly indicated that most sediment deposition occurs in the downstream area. The downstream area contains a gentle slope which leads to a reduction in velocity of flow, which directly reduces the transport capacity of flow and increases sediment deposition. The table below indicates sediment deposition distribution with variation in slope steepness. Table 4.26 indicates that the ratio of sediment deposition to erosion rate is high for gentle slopes. As shown in Table 4.26 below, the ratio of deposition to total erosion rate on areas that has slopes between zeros to three degrees was 0.2 , which was the highest ratio estimated in the watershed. Ratio of $0.13,0.05$ and 0.06 were observed for areas with slope between 3 to 10,10 to 20 , and 20 to 30 degrees respectively.

Table 4.26 Slope steepness, rate of erosion and deposition.

\begin{tabular}{|l|l|l|l|}
\hline $\begin{array}{l}\text { Slope steepness } \\
\text { (degree) }\end{array}$ & $\begin{array}{l}\text { Rate of erosion } \\
\text { (ton/ha/yr) }\end{array}$ & $\begin{array}{l}\text { Rate of deposition } \\
\text { (ton/ha/yr) }\end{array}$ & $\begin{array}{l}\text { Ratio of erosion to } \\
\text { deposition }\end{array}$ \\
\hline Less than 3 & 2 & 0.4 & 0.20 \\
\hline 3 to 10 & 5 & 0.63 & 0.13 \\
\hline 10 to 20 & 31 & 1.43 & 0.05 \\
\hline 20 to 30 & 55.5 & 3.56 & 0.06 \\
\hline
\end{tabular}


Sediment Budget distribution in the Mara river basin

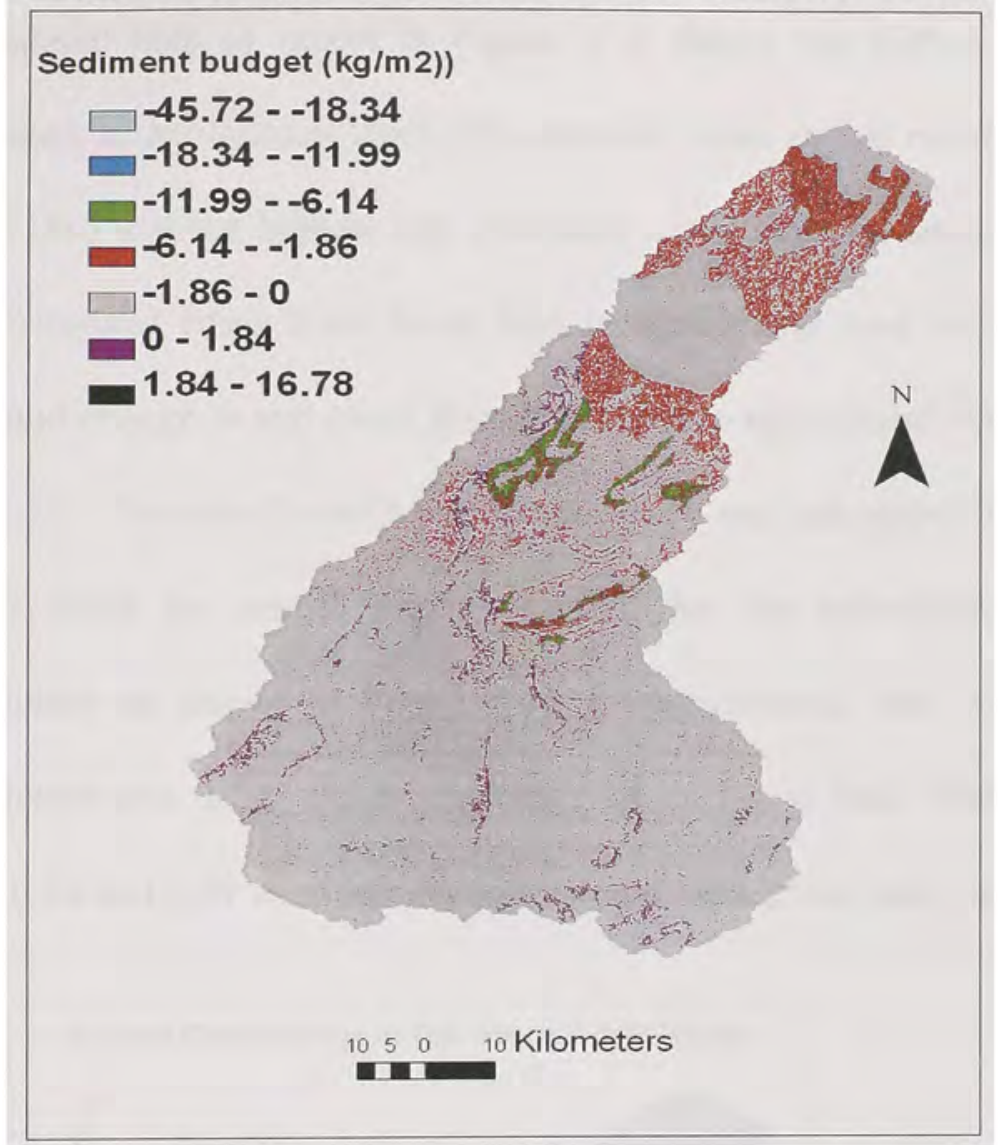

Figure 4.13 Sediment budgets in the Mara River basin from Erosion 3D model.

\subsubsection{Runoff variation in the Mara River basin}

The average annual runoff depth in the Mara River basin was estimated about $258.3 \mathrm{~mm}$ with average runoff coefficient of 0.27 . However, there was variation in runoff with different land cover, slope steepness and soil types. In this section, runoff depth variation in different land uses, slope and soil types as well as their interaction effect is explained. 
The spatial map of runoff in Figure 4.14 shows that higher mean runoff depth was estimated on agricultural lands. The smallest mean annual runoff depth was observed on forest land and the highest was estimated on agricultural lands $(318.3 \mathrm{~mm})$. Change in land uses/land cover from forest land to agricultural land increased runoff volume by $59 \%$ and change in and cover from grass land to agricultural land increased runoff depth by $21.2 \%$. The runoff coefficient in this study was calculated by dividing the estimated runoff depth by annual average rainfall for the watershed. The calculated runoff coefficient as shown in Figure 4.15 for agricultural land was 0.33 and the lowest coefficient was 0.22 , which was observed on forest land. Mean runoff coefficients of $0.25,0.26$ and 0.29 were calculated for wood land, grass land, and bush land respectively.

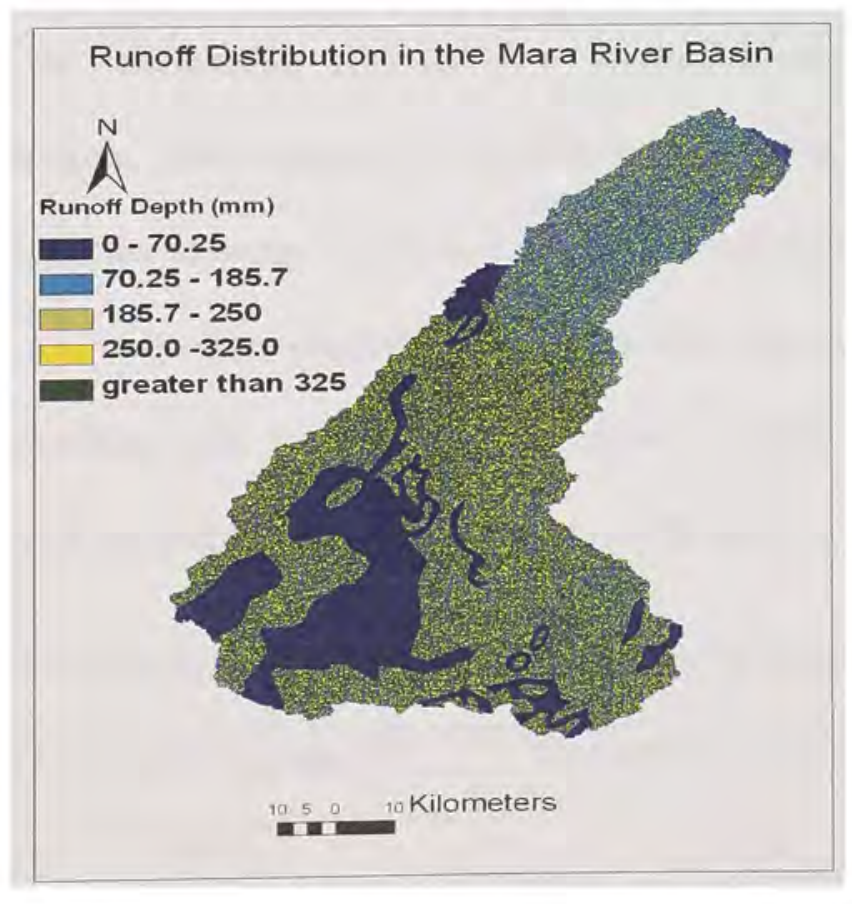

Figure 4.14 Spatial distribution of runoff in the Mara River basin from Erosion 3D model. 
Table 4.27. Annual mean runoff distribution in different land uses

\begin{tabular}{|c|c|c|}
\hline Land use & Runoff depth $(\mathrm{mm})$ & Runoff coefficient \\
\hline Forest & 211.36 & 0.22 \\
\hline Agricultural land & 318.30 & 0.33 \\
\hline bush land & 276.35 & 0.29 \\
\hline grass land & 243.72 & 0.26 \\
\hline Wood land & 241.60 & 0.25 \\
\hline
\end{tabular}

\subsubsection{Runoff variation with soil types}

As shown in Table 4.29 below the runoff distribution significantly varied with soil types. The maximum average runoff depth, $338 \mathrm{~mm}$, was estimated for soil type KE389 and the minimum runoff depth, $21.4 \mathrm{~mm}$ was estimated for KE388 soil type. In this simulation high runoff was estimated for soils that has low sand content and high clay contents. Clay soil has low particle size and low infiltration rate which may lead to high runoff production. The correlation coefficient values, in Table 4.28 below indicate the relationships between soil types and mean runoff depth. Correlation coefficient values of 0.52 and -0.76 were observed for clay particle size content and sand particle size content relationships with runoff depth respectively. There was a non-significant relationship between silt particle content and mean runoff depth in the Mara River basin.

Table 4.28 Relationships between soil particle size and runoff depth

\begin{tabular}{|c|c|c|}
\hline Particle size content (\%) & Correlation coefficient (r) & $\mathrm{p}$ \\
\hline sand & -0.76 & $<0.000001$ \\
\hline clay & 0.51 & 0.002 \\
\hline silt & 0.17 & 0.344 \\
\hline
\end{tabular}


Table 4.29 Soil types, particle size distribution and runoff depth

\begin{tabular}{|c|c|c|c|c|c|}
\hline Soil code & clay $\%$ & silt $\%$ & sand $\%$ & runoff depth $(\mathrm{mm})$ & erosion rate(ton/ha/yr) \\
\hline KE391 & 58 & 26 & 16 & 320.0 & 33 \\
\hline KE381 & 58 & 26 & 16 & 313.2 & 4 \\
\hline KE377 & 58 & 26 & 16 & 307.9 & 7 \\
\hline KE389 & 58 & 26 & 16 & 338.2 & 75 \\
\hline KE200 & 31 & 29 & 40 & 95.5 & 8 \\
\hline KE196 & 42 & 42 & 16 & 202.4 & 68 \\
\hline KE380 & 21 & 26 & 53 & 29.3 & 1 \\
\hline KE378 & 15 & 70 & 15 & 330.45 & 197 \\
\hline KE382 & 25 & 51 & 24 & 323.4 & 24 \\
\hline KE385 & 40 & 15 & 45 & 69.9 & 1 \\
\hline KE383 & 33 & 37 & 30 & 288.4 & 2 \\
\hline KE384 & 58 & 26 & 16 & 310.6 & 4 \\
\hline KE386 & 41 & 29 & 30 & 291.6 & 26 \\
\hline KE387 & 58 & 26 & 16 & 306.6 & 5 \\
\hline KE388 & 20 & 20 & 60 & 21.4 & 0.2 \\
\hline KE57 & 35 & 20 & 45 & 305.6 & 2 \\
\hline KE56 & 60 & 19 & 21 & 298.8 & 5 \\
\hline KE 45 & 9 & 67 & 24 & 44.9 & 8 \\
\hline KE61 & 20 & 30 & 50 & 46.0 & 18 \\
\hline KE58 & 32 & 28 & 40 & 313.0 & 21 \\
\hline KE93 & 15 & 70 & 15 & 320.80 & 192 \\
\hline KE194 & 22 & 50 & 28 & 3190 & 72 \\
\hline KE187 & 38 & 35 & 27 & 325.0 & 54.13 \\
\hline KE183 & 30 & 26 & 44 & 34.5 & 5.6 \\
\hline KE190 & 10 & 28 & 62 & 22.3 & 21 \\
\hline KE192 & 20 & 48 & 32 & 215.4 & 142 \\
\hline
\end{tabular}


4.4 WEPP model application at watershed scales

In this part, the WEPP application at watershed scale is presented. The spatial distribution of runoff and sediment yield at Mara River basin and their variation in different land use are discussed below. Moreover, the results are discussed in relation to the Erosion 3D model.

\subsubsection{Sediment yield variation in the Mara River basin}

As shown in Figure 4.18 below sediment yield estimated in the Mara River basin varied with land uses and slope distribution. High sediment yield was estimated in steep slope areas and agricultural land uses. The rate of sediment yield in agricultural lands with high slope steepness was above $4 \mathrm{~kg}$ per square meter as shown in the spatial map of sediment yield below. The lowest sediment yield was estimated in the downstream watershed, where gentle slopes are located and the land use is grassland and bush lands. The sediment yield that was estimated by WEPP had similar spatial distribution with the one estimated using Erosion 3D, however, high rate of sediment yield was estimated in the Erosion 3D estimation.

According to Jetten et al. (1999), Erosion 3D overestimated sediment yield at watershed scale. The highest sediment yield which was greater than four times the tolerable soil loss ( $\mathrm{T}=11 \mathrm{ton} / \mathrm{ha} / \mathrm{yr}$ ) was estimated in agricultural lands. The estimation was almost similar to the Erosion 3D estimation as evidenced in Figure 4.13. In the downstream side of the watershed, low sediment yield which is less than the tolerable soil loss $(T=11$ ton $/$ ha/yr $)$ 
was estimated. Similar result was obtained using Erosion 3D model and the reason for such low sediment yield may be the land use type (grassland) and steepness of the slope angle, which is gentle slope. In forest land, sediment yield less than the tolerable rate was estimated.

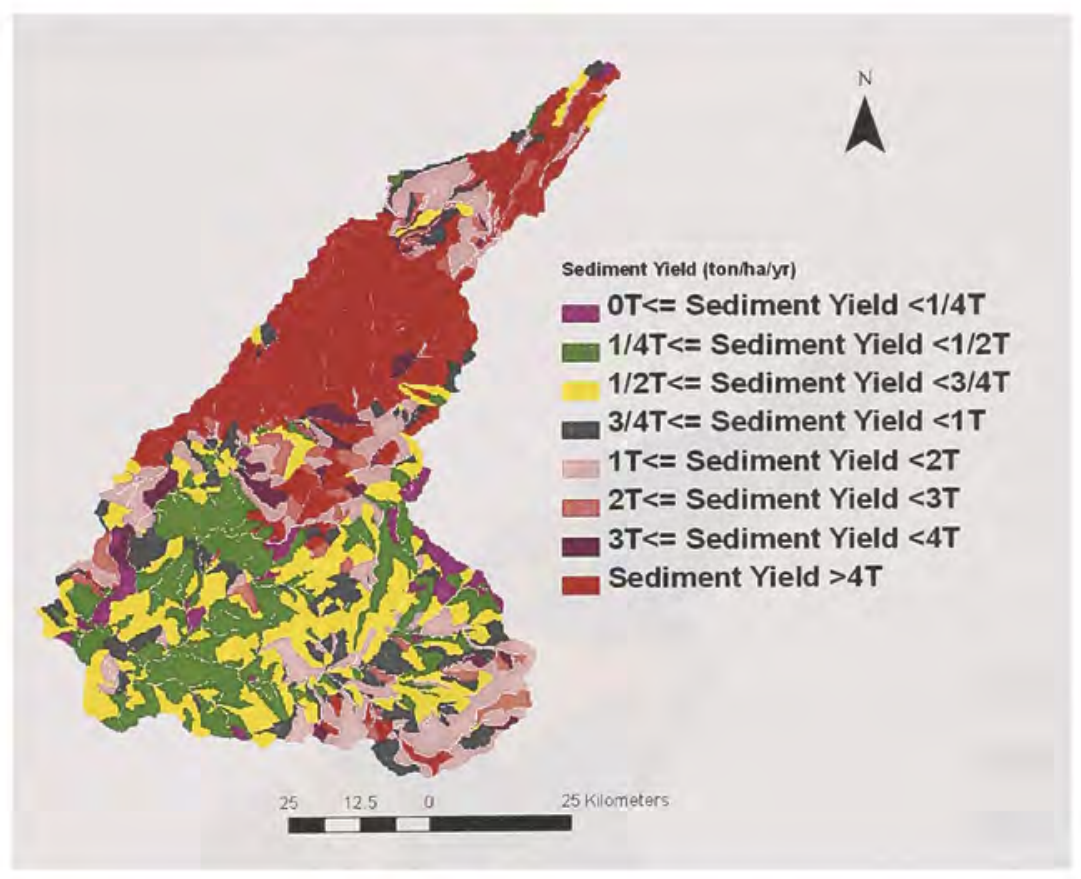

Figure 4. 18 Annual sediment yield variation in Mara River basin from the WEPP model.

\subsubsection{Runoff variation in the Mara River basin using WEPP model}

The mean annual runoff depth estimated using the WEPP model was $270.14 \mathrm{~mm}$, which is almost similar to the average amount estimated using Erosion 3D. Similar to Erosion 3D model, the WEPP model also estimated no significant variation in runoff production with land uses. Runoff depth less than the estimated mean annual depth of the entire watershed was estimated in bush lands in the downstream side. In forest land runoff 
depth between 205 and $250 \mathrm{~mm}$ was estimated and depth greater than $250 \mathrm{~mm}$ was estimated in agricultural lands. The GeoWEPP based watershed delineation resulted in a different watershed extent. This is the reason for the variation in the extent of the map between the Erosion 3D model and the WEPP spatial map output as shown in Figure 4.18 and Figure 4.19.

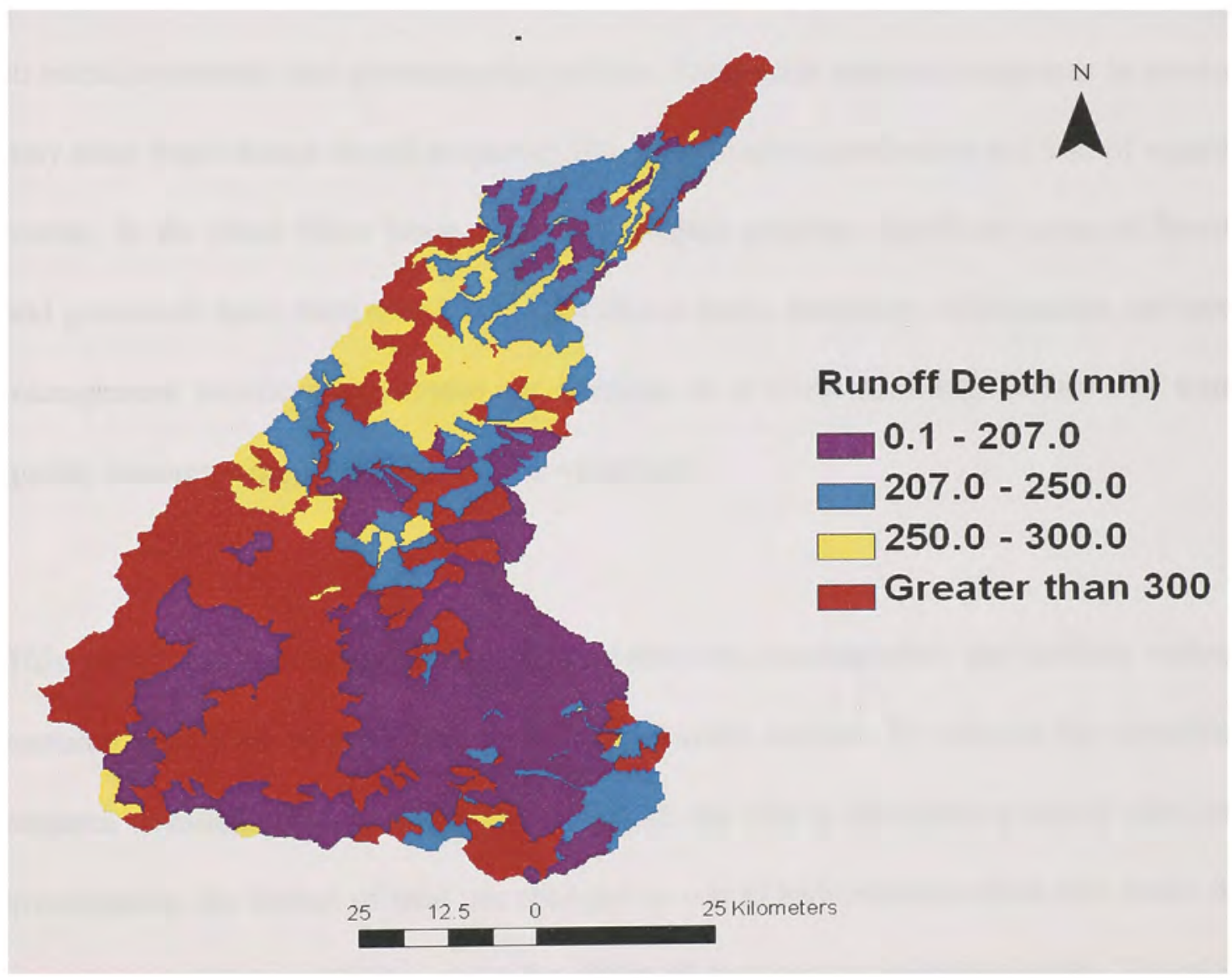

Figure 4.19 Annual runoff depth distributions in the Mara River basin by the WEPP model. 


\section{Chapter 5}

\subsection{Summary and Conclusion}

The severity of erosion varies in time and space. According to Kirkby (1980) and Morgan (1986), soil erosion results from an individual climatic event depend on local topography, soil and land-use conditions. Thus these factors cause regional variation in erosion. Though climatic characteristics vary regionally, land use can change over time in relation to social, economic and governmental policies. Long-term temporal variations in erosion may arise from change in soil properties due to continuous production and loss of organic matter. In the Mara River basin, due to population pressure significant areas of forests and grasslands have been changed to agricultural lands, moreover, deforestation and poor management practices aggravated the situation as a result land degradation and water quality become a major problem of the watershed.

This study was conducted taking this problem into consideration and holding various research questions as described in the introduction section. To address the described research questions, two methods was preferred: the first is establishing runoff plots and investigating the impact of land use changes on runoff and erosion at field plot scale; the second is applying model to assess the effect of land use at watershed scale. The plots were established in three sites: Amala downstream, Amala upstream and Nyangores sub watersheds in grassland, cultivated land and bare lands. The results from the plots indicate that significant erosion and runoff variation with land use was observed in the three sites. The runoff depths observed during the research period in the three sites and 
three land uses at different rainfall event varied from $1.20 \mathrm{~mm}$ in cultivated land at the Nyangores site to $16.39 \mathrm{~mm}$ in bare land at the Amala upstream site. The highest total depth of runoff, $44.02 \mathrm{~mm}$ was observed on bare land in the Nyangores sub-watershed. Runoff also varied with land use in all of the three sites.

The runoff depths observed at the Amala upstream varied from $1.79 \mathrm{~mm}$ in grassland to $16.39 \mathrm{~mm}$ in bare land. The highest total depth of runoff, $26.85 \mathrm{~mm}$ was observed on bare land and $20.14 \mathrm{~mm}$ and $16.20 \mathrm{~mm}$ of total runoff depth during the research period was observed on grassland and cultivated land covered with corn, respectively. The runoff depths observed in the Amala downstream varied from $6.01 \mathrm{~mm}$ in bare land to $1.60 \mathrm{~mm}$ in cultivated land. The highest total depth of runoff, $19.57 \mathrm{~mm}$ was observed on bare land and $17.80 \mathrm{~mm}$ and $15.35 \mathrm{~mm}$ of total runoff depth during the study period were observed on grassland and cultivated land covered with corn, respectively.

The runoff depths observed in the Nyangores watershed varied from $1.20 \mathrm{~mm}$ observed on cultivated land to $16.30 \mathrm{~mm}$ that was observed on bare land. The highest total depth of runoff, $44.02 \mathrm{~mm}$ was observed on bare land and $35.7 \mathrm{~mm}$ and $25.02 \mathrm{~mm}$ of total runoff depth during the research period was observed on grassland and cultivated land covered with corn respectively. The highest total sediment yield was observed on cultivated land with a total of 974.3 gram at the Nyangores site and the lowest sediment yield was observed on grassland with a total of $179.7 \mathrm{gm}$ in the Amala downstream. Similar to runoff, sediment yield in the three sites varied with land uses. At the Amala upstream 
site, the highest total sediment yield was observed on bare lands with a total of 600.57 gram and the lowest sediment yield was observed on grassland with a total of $216.52 \mathrm{gm}$. Sediment yield from cultivated land with corn cover was $528.55 \mathrm{gm}$ and changing land use from grassland to cultivated land may increase sediment yield by $144.1 \%$.

At the Amala downstream sites, the highest total sediment yield of $503.4 \mathrm{gm}$ was observed on bare land and a total of $179.7 \mathrm{~g}$ and $295.1 \mathrm{~g}$ was observed for grassland and cultivated land, respectively. For the studying period, the highest sediment concentration of 12.5 gram per liter was observed on bare land and the lowest sediment concentration of 0.02 gram per litter was observed on grassland. The highest average sediment concentration, $5.21 \mathrm{~g} / \mathrm{L}$, was observed on bare land and $3.6 \mathrm{~g}$ per liter and 2 gram per liter sediment concentration were observed on cultivated land and grassland, respectively. In the Nyangores watershed, the highest total sediment yield per unit area was observed on cultivated land, $162.38 \mathrm{~g} / \mathrm{m}^{2}$ and the lowest sediment yield per unit area was observed on grassland, $53.33 \mathrm{~g} / \mathrm{m}^{2}$. Sediment yield per unit area from bare land, $150.09 \mathrm{gram} / \mathrm{m}^{2}$, was not significantly varied with sediment yield from cultivated land. From the result at plot scale, it may be possible to conclude that runoff as well as sediment yield varied with land uses, and land use changes in the Mara River basin may be responsible for change in water quality of the Mara River basin and expansion of agricultural lands in the watershed may significantly affects the water quality as well as land degradation. 
In addition to plot scale observations, the models were applied to assess potential sediment yield areas and the effect of different land uses on the rate of erosion as well as surface runoff. In this study, the two models were evaluated at field plot scale using the data collected from the three sites and three land uses. The result indicated that both the models estimate runoff well as evidenced from the coefficient of determination for the three sites and land uses. Similarly, sediment yield estimation performance of the Erosion 3D and WEPP models were good, even though the WEPP model estimates better than the Erosion 3D model. The WEPP model underestimate erosion for low rainfall events and overestimate for high rainfall events, however the Erosion 3D model underestimate for higher as well as low rainfall events. Some researchers actually observed underestimation using the Erosion 3D model at watershed scale but at field plot scale the model underestimate for high as well as low rainfall events. The variation in estimation at field and watershed scales may indicate that there is scale effect on the applicability of the model and it may be required to recommend for further research to test the scale effect on the applicability of the erosion 3D model. The simulation result shown that the mean annual erosion in the Mara River basin was about 31 ton $/$ ha, which is about $3 \mathrm{~kg}$ per square meter area. The simulation result also indicated that there was significant variation in sediment yield in different land uses, slope steepness and soil types. The mean annual erosion rate in cultivated land was about 120 ton/ha and this rate was by far greater than the mean annual erosion rate as well as the tolerable erosion rate in the watershed. The lowest mean annual erosion rate was estimated from grasslands with the rate by far less than the tolerable rate as well as the mean annual erosion rate of the watershed. The result indicated that land use and land cover changes may be responsible 
for land degradation in the watershed. Both the model as well as field plot research results indicated that land use and land cover change has significant impact on land degradation and hydrology of the Mara River basin.

The erosion $3 \mathrm{D}$ runoff estimation indicated that the mean annual runoff production in the Mara River basin is about $258 \mathrm{~mm}$ and similar annual depth was estimated using the WEPP model. The estimated result of runoff depth using the Erosion 3D model indicated that high runoff production was estimated in agricultural lands and the least was estimated in bush land. 
Chapter 6

\subsection{Recommendations}

There was limitation in the application of models at watershed scale because of scarcity of input parameters and data base for evaluation of the model at watershed scale. However, for the objectives of this study most of the input parameters were taken following the parameter catalogue. Thus, further research and database development may require evaluating Erosion $3 \mathrm{D}$ as well as other erosion models, and more data may require investigating the effect of different factors on runoff and erosion. In this study, relative difference in erosion rate as well as runoff production was considered at different scale in the watershed, however, such result may need caution to design water conservation and other structures because the model may need to be evaluated at watershed scale and input data including skin-factor may need to be estimated by conducting long term research in the watershed to get accurate result/estimation.

The Erosion 3D model may be appropriate for the watershed since it needs few input parameters and most of the parameters may be collected with little effort and time. Thus

it is better to recommend further evaluation of each components of the model at field, laboratory and watershed scale and modify if it is necessary for the Mara River basin. 
Once the potential sediment sources are identified and the rates are estimated then to take appropriate measures, sound design of conservation structures may be required. To design appropriate structures in the basin, rainfall intensity for different recurrence intervals may be needed. Especially, most conservation structures are designed for five or ten year recurrence interval but such data are not easily obtained for the basin. Thus it may be important to recommend for further research on developing Intensity-DurationFrequency curve for the area. 


\section{REFERENCES}

Ahn, P. M. 1977 Erosion hazard and farming systems in East Africa. In Greenland and Lal 1977,pp.165-176.

Bradford, J. M., and Foster, G. R. 1996. Interrill soil erosion and slope steepness factors. Soil Sci. Soc. Am. J. 60: 909 - 915.

Bradford, J. M., and Huang, C. 1996. Splash and detachment by waterdrops. Soil Erosion, Conservation, and Rehabilitation. In M. Aggassi. Ed. Soils, Plants and The Enver. P. 61 73

Bookhagen B. 2010. Appearance of extreme monsoonal rainfall events and their impact on erosion in the Himalaya. Geomatics, Natural Hazards and Risk Vol. 1, No. 1, March 2010, 37-50.

Bennett, H. H. 1939 Soil conservation. New York: McGraw Hill.

Coppus, R. and Imeson, A.C., 2002, Extreme events controlling erosion and sediment transport in a semi-arid sub-andean valley. Earth Surface Processes and Landforms, 27, pp. 1365-1375.

De ploey, J., and Gabriels, D. 1980. Measuring soil loss and experimental studies. In: M. J. Kirkby and R. P. C. Morgan (eds.) Soil Erosion, Jh. Willey and sons Press, Pp. $63-108$.

Defersha, M.. Study the effect of slope steepness and antecedent moisture content on interrill erosion. MSc. Thesis Alemaya University department of Agricultural Engineering. 2004.

Dregne, H.E. 1990. Erosion and soil productivity in Africa. Journal of Soil and Water Conservation, $45,431-436$.

Dregne, H.E. and Chou, N.T. 1994. Global desertification dimensions and costs. In: Degradation and Restoration of Arid Lands, ed. H.E. Dregne. Lubbock: Texas Technical University.

El-Swaify S.A., Dangler E.W., and Armstrong C.L. Soil erosion by water in the tropics. 1982. College of Tropical Agriculture and Human Resources University of Hawaii Honolulu, Hawaii. 
Eswaran, H., R. Lal and P.F. Reich. 2001. Land degradation: an overview. In: Bridges, E.M., I.D. Hannam, L.R. Oldeman, F.W.T. Pening de Vries, S.J. Scherr, and S. Sompatpanit (eds.). Responses to Land Degradation. Proc. 2nd. International Conference on Land Degradation and Desertification, Khon Kaen, Thailand. Oxford Press, New Delhi, India.

Foster, G. R. 1982. Modeling the erosion process. In: C. T. Haan, H. P. Johnson, and D.

L. Brakensiek (eds.) Hydrologic modeling of small watersheds. ASAE

Monograph No. 5, ASAE, st. Joseph, Michgan. Pp. 295 - 380.

Flanagan, D.C., Nearing, M.A. (Eds.), 1995. USDA-Water Erosion Prediction Project: Hillslope Profile and Watershed Model Documentation. NSERL Rep. No. 10, National Soil Erosion Research Laboratory, USDA ARS, West Lafayette, IN, p. 298.

Flanagan, D.C., Livingston, S.J., (Eds.), 1995. USDA-Water Erosion Prediction Project User Summary. NSERL Rep. No. 11, National Soil Erosion Research Laboratory, USDA ARS, West Lafayette, IN.

Greenland, D.J. 1977. Greenland, D. J., and R. Lal, eds. Soil conservation and management in the humid tropics. Chichester: Wiley.

Huang, C.H., Bradford, J.M., Laflen, J.M., 1996. Evaluation of the detachment transport coupling concept in the WEPP rill erosion equation. Soil Sci. Soc. Am. J. 60, $734-739$.

Hebel B.,Weibel M., Weisshaindinger R., and Katterfeld C. Model verification for EROSION 3D: Effects of downscaling and varying input resolution. Swiss Geoscience Meeting 2005: Zurich $(\mathrm{CH})$.

Hudson N.W.,1971 Soil conservation. Ithaca, NY: Cornell Univ. Press.

Hudson N.W. 1993. Field measurement of soil erosion and runoff. FAO.1993.

Hurni, H (with the assistance of an international group of contributors). 1996. Precious Earth. From Soil and Water Conservation to Sustainable Land Management. Internatl Soil Conserv Org (ISCO), and Centre for Dev and Environ (CDE), Bern.

Jetten, V., De Roo, A., and Favis-Mortlock, D.: 1999, 'Evaluation of field-scale and catchment-scale soil erosion models', Catena. 37, 521-541.

Kirkby, M. J. 1980. Modeling water erosion processes. In: M. J. Kirkby and R. P. C. Morgan (eds.) Soil erosion. Wiley - Intersience Pub. Pp. 183 - 216. 
Mango, L. M.. 2010. Modeling the effect of Land use and climate change scenarios on the water flux of the upper Mara River flow, Kenya. MSc. Thesis Florida International University.

Madsen, H. Parameter estimation in distributed hydrological catchment modeling using automatic calibration with multiple objectives, Adv. Water Resour., 26, 205-216, 2003.

M. A., Klingspor P., and Oduor A. R. The accuracy of manual runoff and sediment sampling from erosion plots. Journal of Soil and Water Conservation. 1996 vol. 51 no. $3231-23$.

Mamedov, A.I., Huang C., and Levy G.J. 2006. Antecedent moisture content and aging duration effects on seal formation and erosion in smectitic soils. Soil Sci. Soc. Am. J. 70:832-843.

Mati B., Mutie S.M., Home P., Felix M., and Gadain H. Land Use Changes in the transboundary Mara basin: A threat to pristine wildlife sanctuaries in East Africa.

Meyer, L. D. 1993. Raifall simulators for soil erosion research. In: R. Lal. (ed.) Soil erosion research methods.( $2^{\text {nd }}$ edition), Soil and Water Conservation Society, St. Lucie Press, Pp. 83 - 101.

Morgan, R.P.C. 1986. Soil Erosion and Conservation. Longman Group UK Limited.

Morgan, R.P.C. 1994. Soil Erosion and Conservation. Silsoe College, Cranfield University.

Mutie S.M., Mati B., Home P., Gadain H., and Gatheny A. Evaluating land use change effects on river flow using USGS geospatial stream flow model in Mara River basin, Kenya. Proceedings of the 2nd Workshop of the EARSeL SIG on Land Use and Land Cover. Center for Remote Sensing of Land Surfaces, Bonn, 28-30 September 2006.

Nash, J. E. and J. V. Sutcliffe. 1970., River flow forecasting through conceptual models part I-A discussion of principles, Journal of Hydrology, 10 (3), 282-290.

Nearing A. Evaluating soil erosion model using measured plot data: Accounting for variability in the data. Earth Surface Processes and Landforms. 2000. 25, 1035 1043 Oxford University Press. Oxford. England. 
Schmidt, J., ed. 1992. Modeling Long-Term Soil Loss and Landform Change, Overland Flow, Hydraulics and Erosion Mechanics, eds. A.J. Abrahams and A.D. Parsons: London.

Schmidt, J., Von Werner, J., \& Michael, A. 1999: Application of the EROSION 3D model to the CATSOP watershed, The Netherlands. Catena 37, 449-456.

Schob, A., Schmidt, J., and Tenholtern, R. 2006. Derivation of site-related measures to minimise soil erosion on the watershed scale in the Saxonian loess belt using the model EROSION 3D. Catena. Volume 68, Issue 2-3. Pp. 153-160.

Schroder A. WEPP, EUROSEM, and E-2D: Results of applications at the plot scale. 2000. Application of physical based models. Scmidt Ed. Springer.2000.

Selby, M.J. (2000): Hillslope Materials and Processes. Second Edition (First Print 1993).

Soil Conservation Service. 1967. Soil Survey Laboratory Methods and Procedures for collecting soil samples. Soil Survey Investigations Report No. 1. U.S. Dept. of Agriculture.

Strahm I. Modelling Hydrology and Sedimentation in the Lake Maybar Area, Wello, Ethiopia Assessment of Potential for Small-Scale Irrigation. 2007. MSc Thesis University of Berne, Switzerland.

Tanner, C.B., and Jackson, M.L. 1947. Monographs of Sedimentation times for soil particles under gravity or centrifugal acceleration. Proc. Soil Sci. Soc. Am. 12: 60-65.

Von Werner, M., 2006. EROSION 3D Manual-A Soil Erosion and Sediment Yield Model 1994.

Wickenkamp, V., Duttmann, R. and Mosimann, T., 2000. A multiscale approach to predicting soil erosion on cropland using empirical and physically based soil erosion models in a geographic information system. In: J. Schmidt (Editor), Soil Erosion: Application of Physically-based Models. Springer, Berlin, Germany, pp. 109-133.

.Zeleke, Gete.2000. Landscape Dynamics and Soil Erosion Process Modelling in the Northwestern Ethiopian Highlands. Geographica Bernensia. African Studies Series. A16.

Berne, Switzerland. 
Zeleke, Gete. 2001. Application and adaptation of WEPP to the traditional farming systems of the Ethiopian Highlands. In: Stott, D.E., Mohtar, R.H., and Steinhardt (eds). 2001. Sustaining the Global Farm. Selected papers from the $10^{\text {th }}$ International Soil Conservation Organization meeting held May 24-29, 1999. Purdue University and the USDA-ARS National Soil Erosion Research Laboratory. Pp. 903-912.

Zhiqiang Zhang, Shengping Wang, Ge Sun, Steven G. McNulty, Huayong Zhang, Jianlao Li, Manliang Zhang, Eduard Klaghofer, and Peter Strauss, 2008. 
Appendix Table 1 Organic matter content and AK4 classification of soil and moisture content

\begin{tabular}{|l|l|l|l|l|l|l|}
\hline Site Name & Silt \% & Sand\% & Clay\% & $\begin{array}{l}\text { KA4 } \\
\text { classification }\end{array}$ & $\begin{array}{l}\text { Average } \\
\text { organic } \\
\text { carbon }\end{array}$ & $\begin{array}{l}\text { Average } \\
\text { organic } \\
\text { matter }\end{array}$ \\
\hline $\begin{array}{l}\text { Amala } \\
\text { upstream }\end{array}$ & 25 & 19.2 & 55.8 & $\begin{array}{l}\text { Loamy clay } \\
\text { (T1) }\end{array}$ & & \\
\hline $\begin{array}{l}\text { Amala } \\
\text { downstream }\end{array}$ & 34 & 16.41 & 49.8 & $\begin{array}{l}\text { Weak Silty } \\
\text { clay( Tu2) }\end{array}$ & 2.85 & 3.18 \\
\hline Nyangores & 22 & 13.2 & 64.8 & $\begin{array}{l}\text { Loamy Clay } \\
\text { (T1) } 1.68\end{array}$ & 2.89 \\
\hline
\end{tabular}

Appendix Table 2 Initial moisture content of soils for Erosion 3D model evaluation at field scale

\begin{tabular}{|l|l|l|l|}
\hline \multicolumn{1}{|c|}{$\begin{array}{l}\text { KA4 Texture } \\
\text { Classification }\end{array}$} & \multicolumn{1}{|c|}{$\begin{array}{c}\text { Initial moisture } \\
\text { content (Dry) }\end{array}$} & $\begin{array}{c}\text { Initial moisture } \\
\text { content at field } \\
\text { capacity }\end{array}$ & $\begin{array}{c}\text { Initial moisture } \\
\text { content at saturation }\end{array}$ \\
\hline T1 (Corn) & 40 & 56.5 & 82.5 \\
\hline T1 (Bare and grass) & 45 & 60 & 84 \\
\hline Tu2 (corn) & 44 & 58 & 85 \\
\hline $\begin{array}{l}\text { Tu2 (Bare and } \\
\text { Grass) }\end{array}$ & 48 & 62 & 88 \\
\hline
\end{tabular}


Appendix Table 3 Erosion 3D input parameters for evaluation

\begin{tabular}{|l|l|l|l|l|l|l|l|l|l|}
\hline & AUC & AUG & AUB & ADC & ADG & ADB & NYC & NYG & NYB \\
\hline Fine clay & 0 & 0 & 0 & 0 & 0 & 0 & 0 & 0 & 0 \\
\hline Medium clay & 56 & 56 & 56 & 50 & 50 & 50 & 65 & 65 & 65 \\
\hline Coarse clay & 0 & 0 & 0 & 0 & 0 & 0 & 0 & 0 & 0 \\
\hline Fine silt & 8 & 8 & 8 & 9 & 9 & 9 & 8 & 8 & 8 \\
\hline Medium silt & 10 & 10 & 10 & 14 & 14 & 14 & 10 & 10 & 10 \\
\hline Coarse silt & 7 & 7 & 7 & 11 & 11 & 11 & 7 & 7 & 7 \\
\hline Fine sand & 3 & 3 & 3 & 2 & 2 & 2 & 3 & 3 & 3 \\
\hline Medium sand & 7 & 7 & 7 & 6 & 6 & 6 & 7 & 7 & 7 \\
\hline Coarse sand & 9 & 9 & 9 & 8 & 8 & 8 & 9 & 9 & 9 \\
\hline $\begin{array}{l}\text { Organic } \\
\text { carbon }\end{array}$ & 1.74 & 1.25 & 1.25 & 1.88 & 1.84 & 1.84 & 1.70 & 1.67 & 1.67 \\
\hline Roughness & 0.05 & 0.15 & 0.013 & 0.075 & 0.3 & 0.013 & 0.1 & 0.25 & 0.013 \\
\hline Cover & 72 & 90 & 0 & 82 & 95 & 0 & 87 & 90 & 0 \\
\hline bulk & 1450 & 1500 & 1500 & 1400 & 1450 & 1450 & 1450 & 1500 & 1500 \\
\hline
\end{tabular}

$\mathrm{AUC}=$ Amala upstream Corn; $\mathrm{ADC}=$ Amala downstream Corn

$\mathrm{AUG}=\mathrm{Amala}$ upstream Grass; $\mathrm{ADG}=$ Amala downstream Grass

$\mathrm{AUB}=$ Amala upstream Bare; $\mathrm{ADB}=$ Amala downstream Bare; $\mathrm{NYC}=$ Nyangores Corn; $\mathrm{NYB}=$ Nyangores Bare; $\mathrm{NYG}=$ Nyangores Grass 
Appendix Table 4 slope steepness variation with land uses

\begin{tabular}{|l|l|l|l|l|l|}
\hline $\begin{array}{l}\text { Slope } \\
\text { (degree) }\end{array}$ & Agriculture & Wood land & Grass & Bush land & Forest \\
\hline $0-10$ & 0.83 & 0.89 & 0.99 & 0.94 & 0.74 \\
\hline $10-20$ & 0.12 & 0.1 & 0.01 & 0.05 & 0.21 \\
\hline $20-30$ & 0.04 & 0.01 & 0.0 & 0.01 & 0.04 \\
\hline above 30 & 0.01 & 0.0 & 0 & 0.00 & 0.00 \\
\hline
\end{tabular}

* mixed land (grass with bush)

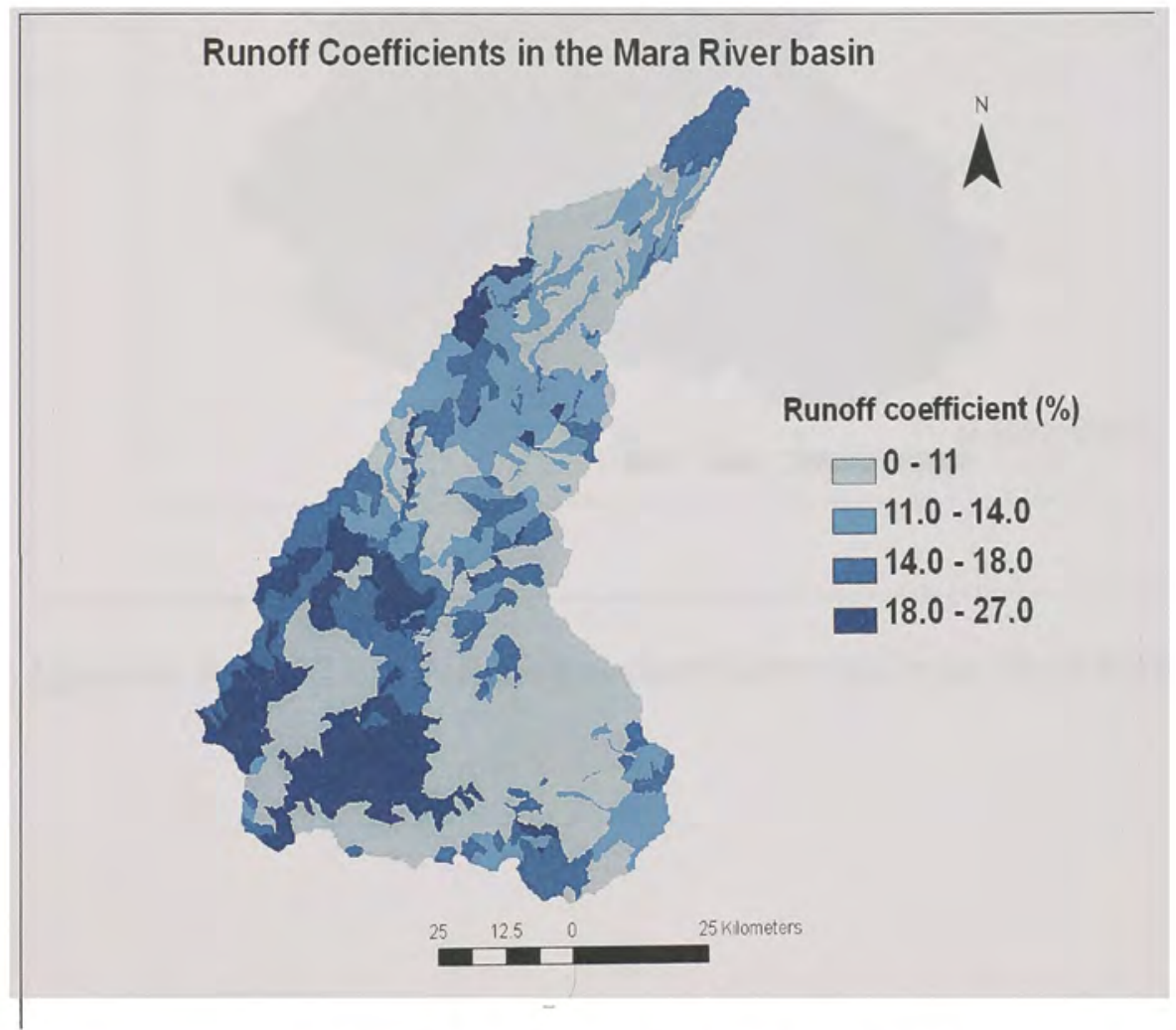

Appendix figure 1 Runoff coefficient as calculated from WEPP estimation 


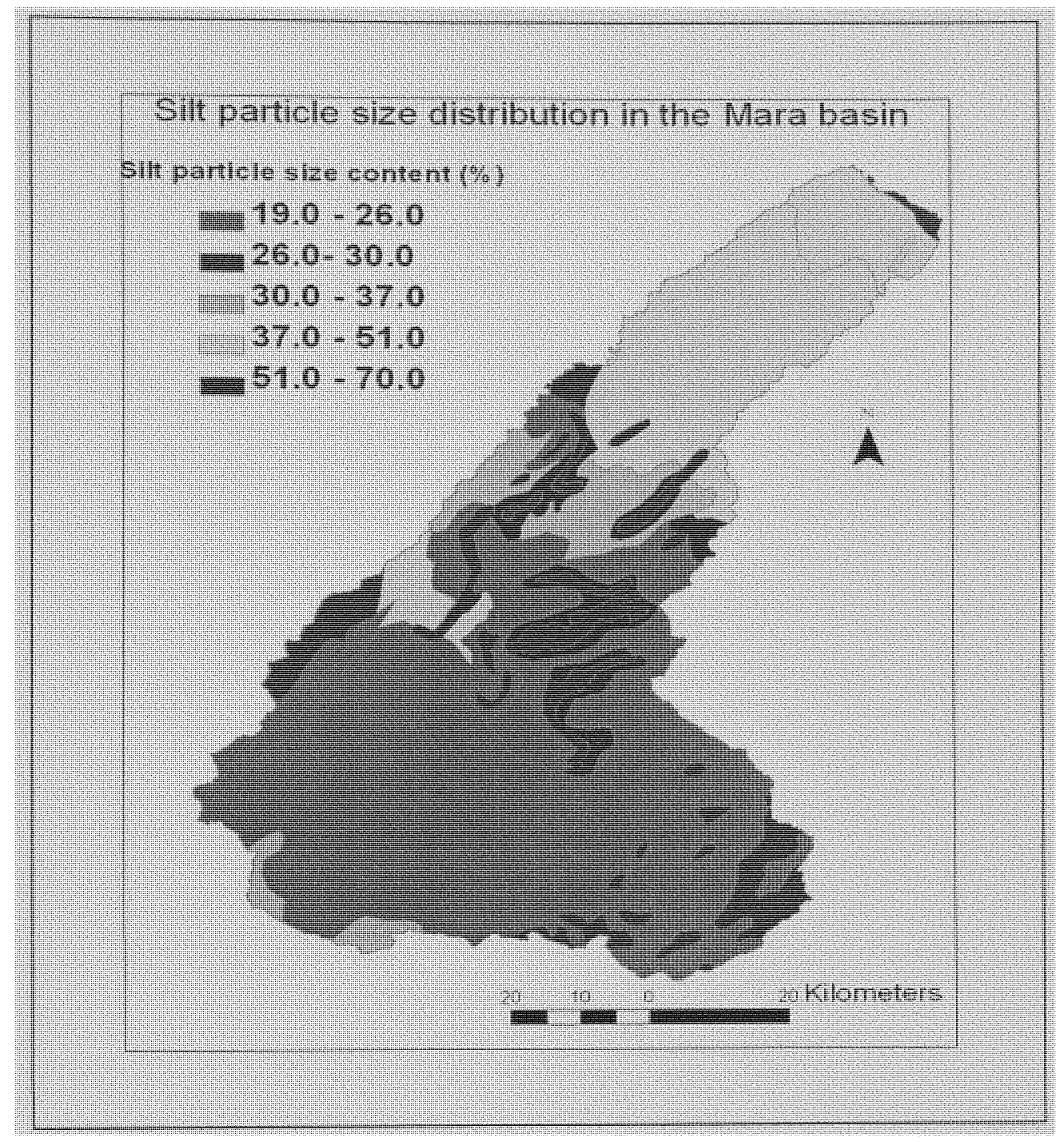

Appendix Figure 2 Silt Particle size distribution (\%) in the Mara River basin 